LETÍCIA PELLUCI DUARTE MORTOZA

ANTECIPAÇÃO DE CRISES FINANCEIRAS POR MEIO DE MEDIDAS DE COMPLEXIDADE: EVIDÊNCIAS DO BRASIL 


\section{ANTECIPAÇÃO DE CRISES FINANCEIRAS POR MEIO DE MEDIDAS DE COMPLEXIDADE: EVIDÊNCIAS DO BRASIL}

Tese apresentada à Escola Politécnica da Universidade de São Paulo para a obtenção do título de Doutora em Ciências.

Área de Concentração: Engenharia de Sistemas

Orientador: Prof. Dr. José Roberto Castilho Piqueira

São Paulo 
Mortoza, Leticia Pelluci Duarte

ANTECIPAÇÃO DE CRISES FINANCEIRAS POR MEIO DE MEDIDAS DE COMPLEXIDADE: EVIDÊNCIAS DO BRASIL / L. P. D. Mortoza -- São Paulo, 2017.

$103 \mathrm{p}$.

Tese (Doutorado) - Escola Politécnica da Universidade de São Paulo. Departamento de Engenharia de Telecomunicações e Controle.

1.Complexidade 2.mercado financeiro 3.crise financeira 4.câmbio I.Universidade de São Paulo. Escola Politécnica. Departamento de Engenharia de Telecomunicações e Controle II.t. 


\section{Agradecimentos}

"Não sabendo que era impossível, foi lá e fez".

(Jean Cocteau)

Agradeço primeiramente ao querido Professor Piqueira que, mesmo diante de todas as dificuldades, nunca deixou de acreditar no nosso trabalho. Sua presença foi especial desde o primeiro dia de aula de álgebra linear no MBA em Engenharia Financeira, o qual eu nunca irei esquecer, aproximadamente oito anos atrás. Sempre me incentivou e me deu forças para continuar, mesmo nos piores momentos. E, claro, teve coragem suficiente para aceitar o desafio de se enveredar por um mundo desconhecido: o mercado financeiro. Agradeço ao Professor Oswaldo, que tem me acompanhado desde a mesma época, e de certa forma também fez parte deste projeto.

Agradeço aos meus pais, que me ensinaram o valor do estudo desde pequena; não como uma obrigação, mas sim como um prazer. À minha querida irmã Marina que, assim como os meus pais, sempre me apoiou e me ajudou muito, principalmente revisando meu português. Sua energia positiva foi decisiva nestes últimos dias de luta! Ao "pequeno" irmão Bernardo, que me fez viver uma experiência única, e me trouxe muita alegria desde seus primeiros dias de vida!

Agradeço a todos os amigos que estiveram à minha volta por todos estes anos, dando muito mais cor à minha vida. Agradeço especialmente ao Renatinho, que contribuiu decisivamente com a coleta dos dados; e ao Fabrício, que me ajudou bastante com a bibliografia econômica.

Enfim, foram cinco anos, vários empregos em diferente Bancos, e residência em três países: Brasil, Inglaterra e Dinamarca. Agradeço a todos que fizeram, e fazem parte desta jornada! Eu sou realmente uma pessoa muito privilegiada e grata por ter todos vocês! 
"I think the next century will be the century of Complexity".

(Stephen Hawking, Janeiro 2000) 


\section{Resumo}

O clássico Equilíbrio Econômico nunca foi realidade, especialmente após as primeiras crises dos mercados financeiros. Hoje se sabe que as economias estão longe da situação de equilíbrio, sendo vistas mais como um processo em construção do que um estado estático propriamente dito. Se assemelham a um sistema estocástico, e não determinístico como um dia se pensou.

O Brasil é um país jovem, e seus sistemas econômico e político ainda estão em formação. Tendo em vista todas as mudanças e crises que o país tem sofrido em sua história recente, este estudo busca uma forma alternativa para que tais eventos possam ser detectados e, principalmente, de certa forma antecipados, para que as providências cabíveis possam ser tomadas a tempo de se evitar grandes perdas financeiras.

Para tal, as medidas de Complexidade de SDL e LMC são aplicadas às séries do câmbio dólar-real, lbovespa e CDS Brasil e avaliadas durante eventos de crises. Detectados os principais eventos de cada série, "volta-se no tempo", ao início da crise, e avalia-se, dada a informação disponível naquele momento, a possibilidade de se detectar a crise em seus primeiros estágios.

Ao fim, conclui-se que as Medidas de Complexidade LMC e SDL são robustas na detecção de aumentos de volatilidade nos dados de séries financeiras. Assim sendo, apresentam grande potencial como indicadores precoces de crises financeiras. Para tal, não são necessários cálculos extensivos, nem grandes históricos de dados; e também não são necessárias hipóteses sobre a distribuição de probabilidades destes dados. Acredita-se que este seja o primeiro passo em direção à construção de um monitor de crises em tempo real.

Palavras-chave: mercados financeiros, crise, Medidas de Complexidade, taxa de câmbio dólar-real, Ibovespa, CDS Brasil. 


\begin{abstract}
The classical Economic Equilibrium has never been a reality, especially after the first financial markets crisis events. It is known nowadays that economies are far from their Equilibrium, they are seen more as a process under construction, not a static state; a stochastic instead of deterministic process, as it was thought before.

Brazil is a young country, hence its economic and political systems are still maturing. In light of all the changes and crises it has been suffering in the recent history, this research seeks for an alternative mechanism to detect and anticipate these crisis events, in order to avoid massive financial losses.

To this end, the LMC and SDL Complexity Measures are applied to the DollarReal exchange rates, Ibovespa and Brazilian CDS time series during crisis events. After detecting the main events, the idea is to "turn back in time", to the events' inception, and analyse if, given the limited amount of information on that time, the crises could be detected on their early stages.

Finally, this research concludes that both LMC and SDL Complexity Measures are robust in detecting volatility increases on the financial series, revealing good potential as crises early warning. However, no extensive calculus, large samples, or strong assumptions about the data probability distributions are needed to this aim. Therefore, these results represent the very first step towards a crises real time monitor.
\end{abstract}

Keywords: financial markets, crisis, Complexity Measures, Dollar-Real exchange rates, Ibovespa, Brazilian CDS. 


\section{Lista de Figuras}

Figura 1 - Constituição de Um Sistema de Comunicação ……………………........ 20

Figura 2 - Decomposição de uma escolha com três possibilidades .......................... 21

Figura 3 - As três categorias de Complexidade como função da desordem ............. 26

Figura 4 - Complexidade como função da Informação e Desequilíbrio, para o cristal e

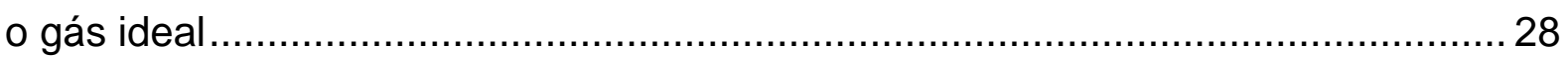

Figura 5 - Spread dos títulos brasileiros comparado aos títulos de países

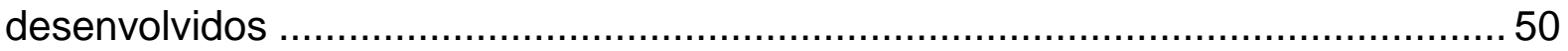

Figura 6 - Risco Brasil: EMBI (final de período) ………..................................... 50

Figura 7 - Spread e retorno do EMBI+ (2000 a 2006) ............................................ 55

Figura 8 - Variação anual do Produto Interno Bruto do Brasil ...................................59

Figura 9 - Como funciona o CDS soberano do Brasil............................................. 67 


\section{Lista de Gráficos}

Gráfico 1 - Série histórica do câmbio e lbovespa durante janeiro de 1999 45

Gráfico 2 - Série histórica do câmbio e lbovespa durante agosto, setembro e outubro de 2001 46

Gráfico 3 - Série histórica do CDS Brasil durante 2002 e 2003 51

Gráfico 4 - Série histórica do câmbio e lbovespa durante 2002 e 2003. 52

Gráfico 5 - Série histórica do câmbio e lbovespa, no período de 2007 a 2010 57

Gráfico 6 - Série histórica do CDS Brasil, no período de 2007 a 2010 57

Gráfico 7 - Série histórica do câmbio e do lbovespa, no período de janeiro de 2014 a setembro de 2016 62

Gráfico 8 - Série histórica do CDS Brasil, no período de janeiro de 2014 a setembro de 2016 63

Gráfico 9 - Série histórica do câmbio e lbovespa e os eventos de crise 66

Gráfico 10 - Série histórica do CDS Brasil e os eventos de crise. 68

Gráfico 11 - CDS Brasil e o câmbio dólar-real 69

Gráfico 12 - Ibovespa - Crise Subprime. 72

Gráfico 13 - Complexidade da Taxa de Câmbio, 8 intervalos 73

Gráfico 14 - Complexidade da Taxa de Câmbio, 16 intervalos 73

Gráfico 15 - Complexidade da Taxa de Câmbio, 32 intervalos 74

Gráfico 16 - Complexidade da Taxa de Câmbio, 64 intervalos 74

Gráfico 17 - Complexidade da Taxa de Câmbio e Eventos de Crise, 64 intervalos 77 Gráfico 18 - Taxa de Câmbio - Crise Pré-Eleição do Lula: amostras pré-crise e crise 78

Gráfico 19 - Complexidade da Taxa de Câmbio - Crise Pré-Eleição do Lula 78 Gráfico 20 - Taxa de Câmbio - Crise do Governo Dilma: amostras pré-crise e crise 80

Gráfico 21 - Complexidade da Taxa de Câmbio - Crise do Governo Dilma 82

Gráfico 22 - Complexidade do lbovespa, 8 intervalos 83

Gráfico 23 - Complexidade do Ibovespa, 16 intervalos 83

Gráfico 24 - Complexidade do lbovespa, 32 intervalos 84 
Gráfico 25 - Complexidade do Ibovespa, 64 intervalos 84

Gráfico 26 - Complexidade do lbovespa, 64 intervalos, e os eventos de crise 87

Gráfico 27 - Ibovespa - Crise Subprime: amostras pré-crise e crise ..................... 88

Gráfico 28 - Complexidade do Ibovespa - Crise Subprime................................... 88

Gráfico 29 - Complexidade do CDS Brasil, 8 intervalos .......................................... 89

Gráfico 30 - Complexidade do CDS Brasil, 16 intervalos ...................................... 90

Gráfico 31 - Complexidade do CDS Brasil, 32 intervalos .........................................90

Gráfico 32 - Complexidade do CDS Brasil, 64 intervalos .......................................91

Gráfico 33 - Complexidade do CDS Brasil, 64 intervalos, e eventos de crise .......... 93

Gráfico 34 - Complexidade do CDS Brasil, Crise Pré-Eleição do Lula..................... 94

Gráfico 35 - Complexidade do CDS Brasil - Crise Pré-Eleição do Lula................... 95 


\section{Lista de Tabelas}

Tabela 1 - Complexidade da Taxa de Câmbio, 64 intervalos ................................ 76

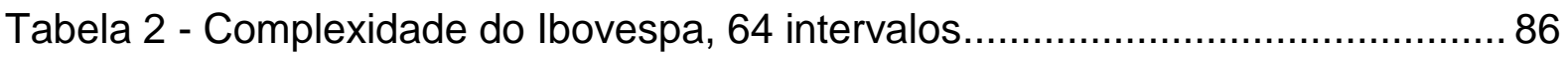

Tabela 3 - Complexidade do Ibovespa, 64 intervalos...................................... 92 


\section{Sumário}

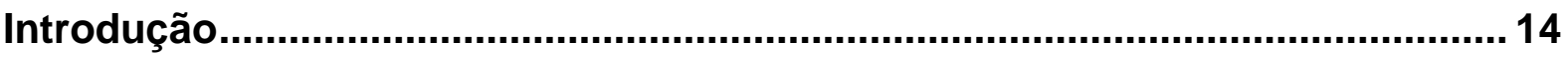

1 Teoria da Comunicação, Entropia e Complexidade ........................................ 17

1.1 Teoria da Comunicação e Entropia ........................................................... 17

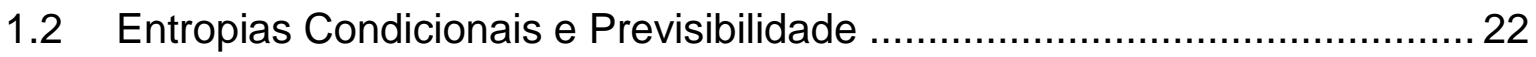

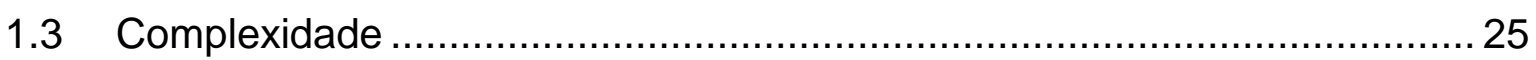

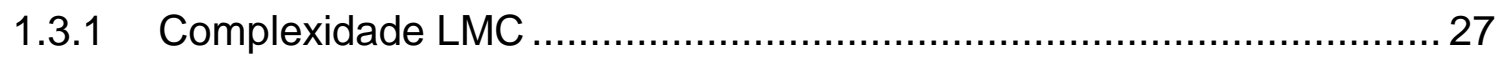

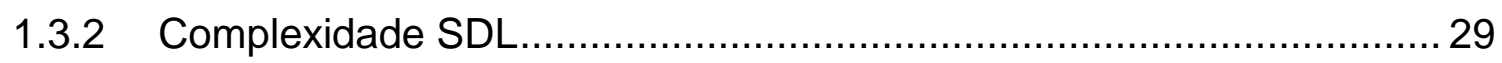

1.4 Aplicação da Teoria da Informação aos Mercados Financeiros ....................31

2 História Econômica do Brasil e Eventos de Crise.............................................37

2.1 História Econômica do Brasil ..................................................................... 37

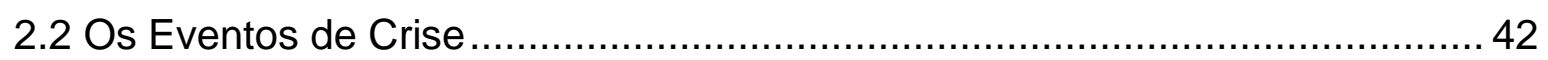

2.2.1 A Crise Cambial de 1999 .................................................................. 43

2.2.2 O Ataque Terrorista às Torres Gêmeas (2001) ..................................... 45

2.2.3 A Crise Pré-Eleição do Lula (2002) ....................................................... 47

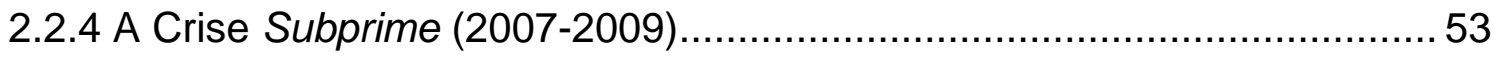

2.2.5 A Crise do Governo Dilma Rousseff $(2015,2016)$............................... 58

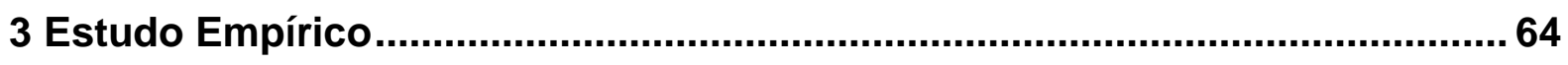

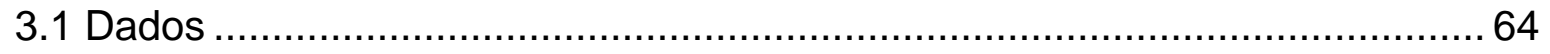

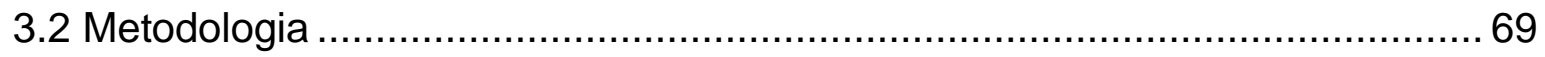

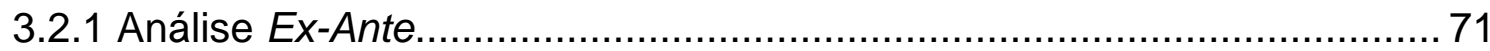




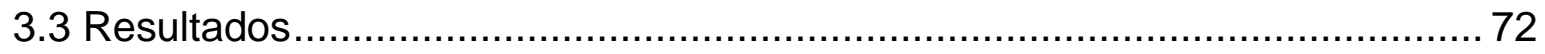

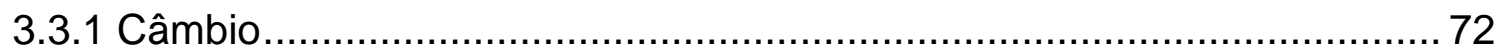

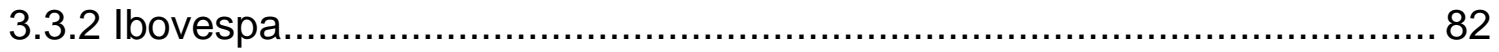

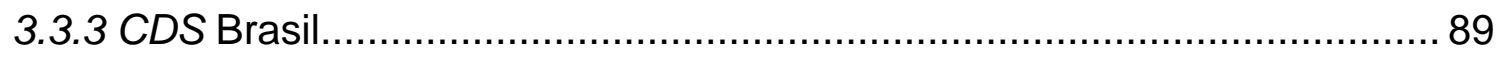

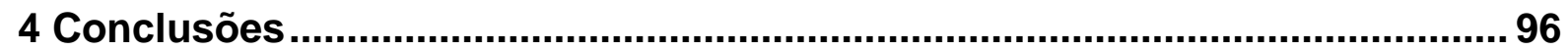

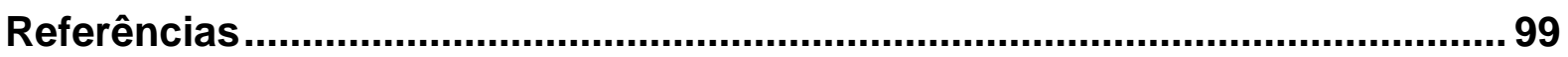




\section{Introdução}

"Complexity science is moving us away from a linear, mechanistic view of the world, to one based on nonlinear dynamics, evolutionary development and systems thinking. It represents a dramatic new way of looking at things; not just looking at more things at once" (SANDERS, 2000).

Atualmente as palavras "caótica" e "complexa" são usadas diariamente para definir situações que vão desde o tráfico de veículos no horário de rush em grandes cidades, ou um aeroporto após uma tempestade de neve, até desastres naturais como furacões e tsunamis, ou as complicadas relações políticas no Oriente Médio. Mas poucas pessoas sabem o que estes conceitos realmente significam e como esta nova ciência, Sistemas Complexos, pode contribuir para o entendimento de eventos inesperados:

"Chaos is the science of surprises, of the nonlinear and the unpredictable. It teaches us to expect the unexpected" (FRACTAL FOUNDATION).

"Simply stated, complexity arises in situations where an increasing number of independent variables begin interacting in interdependent and unpredictable ways. Traffic, the weather, the stock market and the United Nations are examples of complex systems" (SANDERS, 2000).

Sob a luz desta nova ciência, conceitos como o Equilíbrio Econômico têm sido questionados. A Economia já não é mais entendida como um sistema pronto, em equilíbrio, mas sim em construção por meio de instituições, desenvolvimento tecnológico e, é claro, choques. Nos últimos vinte e cinco anos, uma nova forma de estudar a Economia tem sido desenvolvida, a Complexity Economics, para a qual a Economia não está necessariamente em equilíbrio, mas em movimento, em "construção perpétua". Enquanto o Equilíbrio Econômico enfatiza ordem, determinismo e imobilismo, a Complexity Economics trabalha com indeterminação e abertura a mudanças (ARTHUR, 2013).

O comportamento do mercado financeiro, de forma geral, está longe de ser determinístico, e é amplamente conhecido como estocástico. O Brasil é um país novo, 
e sua economia, e especialmente o mercado financeiro, está definitivamente em construção, sendo extremamente sensível ao apetite de risco do investidor estrangeiro. Ou seja, o país ainda está muito longe de alcançar um Equilíbrio Econômico, de forma que a Complexity Economics é uma abordagem mais adequada à realidade brasileira.

Tendo em vista todas as mudanças e crises que o Brasil tem sofrido em sua história recente, este estudo busca uma forma alternativa de criar um mecanismo para que tais eventos possam ser detectados e, principalmente, de certa forma antecipados, para que as providências cabíveis possam ser tomadas a tempo de se evitar grandes perdas financeiras. Aqui, "antecipar" é usado no sentido de "detectar em seu início", e não de "prever" (antes do início).

Para tal, as medidas de Complexidade de $S D L^{1}$ e $L M C^{2}$ são aplicadas às séries do câmbio dólar-real, Ibovespa e $C D S^{3}$ Brasil e avaliadas durante eventos de crises. Busca-se analisar, por meio da aplicação da Teoria da Comunicação, e do conceito físico de Entropia, a quantidade de informação contida no sistema dinâmico destes indicadores. Usando estas medidas, chega-se ao grau de Complexidade do sistema em diversos instantes, o que possibilita a análise do comportamento desta medida no tempo, especialmente durante eventos extremos, hoje popularmente conhecidos como crises financeiras.

Detectados então os principais eventos de crises de cada série, a ideia é "voltar no tempo", ao início da crise, e avaliar se, dada a informação disponível naquele momento, seria possível detectar a crise em seus primeiros estágios. Este seria o primeiro passo em direção a criação de um "monitor de crises em tempo real".

Este estudo está dividido em quatro capítulos, além desta introdução. O primeiro capítulo resume a Teoria da Comunicação, desde as primeiras publicações no Bell System Technical Journal até os dias de hoje. Faz também uma revisão do uso dos conceitos de Entropia e Complexidade na literatura financeira atual. A Economia Brasileira é então o foco do segundo capítulo. É contada a história de seu comportamento nas últimas seis décadas e são analisados importantes fatos que

\footnotetext{
1 Shiner, Davidson e Landsberg

2 Lopez, Mancini e Calbet

${ }^{3}$ Credit Default Swap
} 
levaram ao sistema econômico que existe hoje. Ao final são descritos os eventos de crise analisados neste estudo, e seus respectivos impactos no mercado financeiro brasileiro. O terceiro capítulo cuida da parte empírica deste trabalho. É descrita a metodologia aqui utilizada, são analisados os dados e, por fim, são apresentados os resultados encontrados. Finalmente, o quarto e último capítulo narra as conclusões a que este estudo permite chegar e sugere pesquisas futuras. 


\section{Teoria da Comunicação, Entropia e Complexidade}

Este capítulo tem como objetivo descrever o desenvolvimento da teoria precursora das medias de informação neste estudo utilizadas. Para tal, volta-se às décadas de 1920 e 1940, quando foram publicadas as primeiras tentativas de quantificar informação no famoso Bell System Technical Journal. Desde então muito foi desenvolvido, e estas medidas se espalharam por diversos campos de estudo, da Biologia à Psicologia, da Física aos mercados financeiros. Desta forma, o capítulo se inicia com a teoria de Claude Shannon e seus antecessores na Bell System, passando pelo conceito de Entropia e chegando à medida de Complexidade. Descreve então as medidas de Complexidade de LMC e SDL e mostra as recentes aplicações destes conceitos aos dados de mercados financeiros.

\subsection{Teoria da Comunicação e Entropia}

O conceito de entropia foi primeiramente introduzido na Física por Rudolf Clausius em 1864, e, em um contexto diferente, por Claude Shannon em 1948 (EBELING, 2002). A Entropia de Shannon é um conceito-chave para a Teoria da Informação Clássica (NIELSEN E CHUANG, 2016). Porém, de acordo com SHANNON (1948), a base desta teoria pode ser encontrada nos artigos de Nyquist (1924) e Hartley (1928), também publicados no Bell System Technical Journal. Devido à grande e inesperada popularidade alcançada pelo tralho de Shannon, em 1964 a Universidade de Illinois lançou o livro The Mathematical Theory of Communication, contendo não apenas o seu artigo, mas também o trabalho de Weaver, que expandiu e atualizou o conceito. Assim nascia a Teoria da Comunicação.

Comunicação, em seu sentido mais amplo, é todo procedimento pelo qual um mecanismo afeta um outro mecanismo (WEAVER, 1964). A parte semântica da comunicação não é relevante para a engenharia, o aspecto significativo é o fato de que a mensagem atual foi escolhida entre um conjunto de possíveis mensagens (SHANNON, 1948). Ou seja, a quantificação da informação está mais ligada ao que 
se poderia dizer, do que ao que propriamente se diz, ou a liberdade de escolha da mensagem. Desta forma, informação não pode ser confundida com significado.

Nyquist (1924) estuda a transmissão de inteligência por meio da escolha dos códigos e do formato do sinal. Aqui foca-se apenas na parte da escolha dos códigos, já que as questões técnicas dos sinais fogem ao escopo deste estudo, que se atém à aplicação da Teoria da Informação ao mercado financeiro brasileiro - pode-se pensar nos preços diários como códigos "escolhidos" dentro de uma distribuição de probabilidades. $O$ autor define então a velocidade de transmissão da mensagem como o logaritmo do número de valores disponíveis para a escolha:

$$
W=K \log m
$$

onde $W$ é a velocidade de transmissão, $K$ é uma constante arbitrária e $m$ é o número de valores possíveis. Esta equação foi usada como base para a construção da medida de informação desenvolvida posteriormente por SHANNON (1948).

Hartley (1928) desenvolve uma medida quantitativa da informação baseada em elementos físicos, isolando-os dos aspectos psicológicos. De acordo com o autor, para se estimar a capacidade de um sistema físico de transmitir informação, a questão da interpretação deve ser ignorada. Seu maior objetivo era criar uma medida que permitisse a comparação da capacidade de transmissão de distintos sistemas.

Eliminado o fator psicológico, a medida de informação deve ser proporcional ao número de símbolos disponíveis para seleção, assim como em Nyquist (1924). Desta forma, para um determinado sistema, a quantidade de informação associada a $n$ seleções seria:

$$
H=K n
$$

Onde $K$ é uma constante que depende do número $s$ de símbolos disponíveis em cada seleção. Seleciona-se 2 sistemas quaisquer, nos quais $s$ tem valores $s_{1}$ e $s_{2}$, correspondentes às constantes $K_{1}$ e $K_{2}$. Estas são definidas de forma que, independente dos números de seleções $n_{1}$ e $n_{2}$ para os dois sistemas, o número de sequencias possíveis é o mesmo, ou seja, a quantidade de informação é a mesma para ambos:

$$
s_{1}{ }^{n_{1}}=s_{2}{ }^{n_{2}}
$$




$$
H=K_{1} n_{1}=K_{2} n_{2}
$$

e

$$
\frac{K_{1}}{\log s_{1}}=\frac{K_{2}}{\log s_{2}} .
$$

A relação acima é válida para todos os valores de $s$ apenas se $K$ está conectado a $s$ por meio da seguinte relação:

$$
K=K_{0} \log s_{1}
$$

onde $K_{0}$ é a mesma para todos os sistemas. Como $K_{0}$ é um valor arbitrário, pode ser omitido. Voltando à equação (2):

$$
\begin{aligned}
& H=n \log s \\
& H=\log s^{n} .
\end{aligned}
$$

Desta forma, a medida de informação nada mais é do que o logaritmo do número de sequências possíveis (HARTLEY, 1928).

Shannon (1948) expande a teoria desenvolvida por seus antecessores no Bell System Journal, acrescentando fatores como ruídos no canal de transmissão. São estudados três casos distintos: canais discretos sem ruídos, canais discretos com ruídos e canais contínuos.

De acordo com o autor, um sistema de comunicação é constituído de uma fonte de informação, que seleciona uma mensagem (dentre várias possíveis), que é então codificada por um transmissor em um sinal, e enviada a um receptor, por meio de um canal de comunicação, que, em certos casos, está também sujeito a ruídos: 
Figura 1 - Constituição de Um Sistema de Comunicação

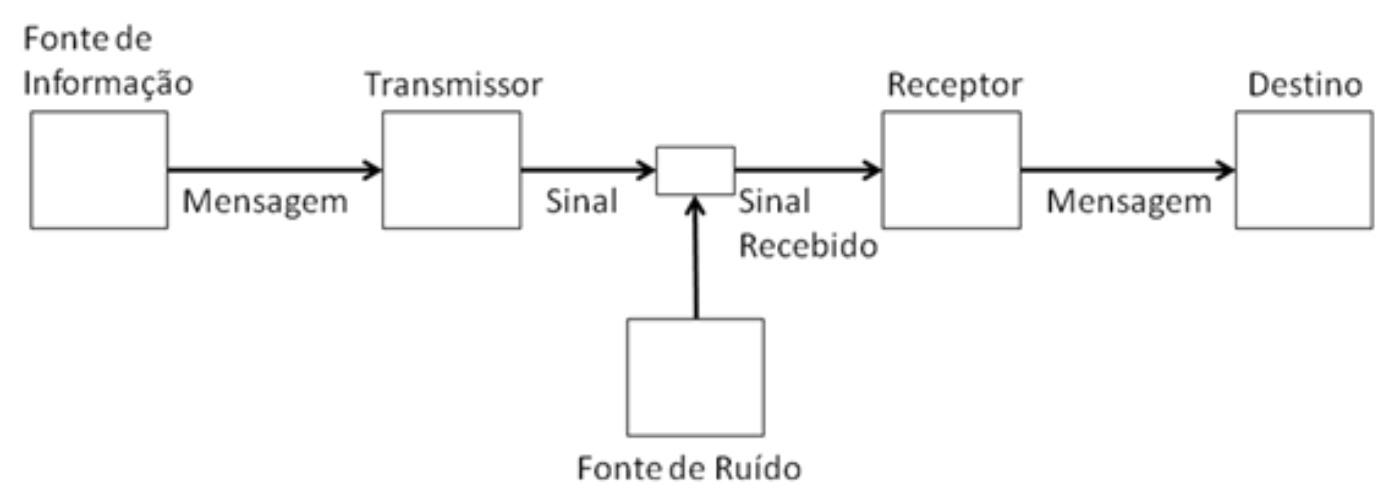

Fonte: SHANNON (1948).

Estes sistemas podem ser classificados em três categorias: discretos, contínuos e mistos. Sistema discreto é aquele em que a mensagem e o sinal são sequências de símbolos discretos. No sistema contínuo, mensagem e sinal são tratados como funções contínuas. Já um sistema misto é uma combinação dos outros dois.

Em termos da primeira categoria, pode-se pensar em uma fonte discreta de informação gerando as mensagens, símbolo por símbolo. Os símbolos são escolhidos de acordo com certas probabilidades dependendo, em geral, dos símbolos precedentes. Um sistema que produz este tipo de sequencias governadas por um conjunto de probabilidades é chamado de processo estocástico. Séries de dados financeiros são consideradas processos estocásticos, já que cada realização do processo está associada a uma probabilidade, normalmente ligada à realização anterior. Por esta razão, este estudo trata apenas de sistemas discretos, sem ruídos.

Processos estocásticos como os descritos acima são também conhecidos como Processos de Markov, nos quais existe um número finito de estados possíveis no sistema: $S_{1}, S_{2}, \ldots S_{n}$; e um conjunto de probabilidades: $p_{i}(j)$ de o sistema no estado $S_{i}$ passar para o estado $S_{j}$. Para que sistemas como esse sejam considerados uma fonte de informação, basta assumir que um símbolo seja produzido para cada transição de um estado para o outro. Os estados seriam então considerados como o "resíduo" da influência dos símbolos anteriores (SHANNON, 1948). 
Posto que a fonte de informação é um processo Markoviano, pode-se definir uma quantidade que possa medir quanto de informação é produzido em tal processo. Supondo-se um conjunto de possíveis eventos cujas probabilidades de ocorrência $p_{1}, p_{2}, \ldots p_{n}$ são conhecidas, pode-se encontrar uma medida do "tamanho" da possibilidade de escolha envolvida na seleção do evento e do quão incerto é o seu resultado. Tal medida deve ter as seguintes propriedades:

1. Deve ser contínua para todo $p_{i}$;

2. Se os eventos são equiprováveis, $p_{i}=1 / n$, então a informação deve ser uma função monotonicamente crescente em $n$, de forma que quanto maior for o número de eventos possíveis, maior a incerteza, e portanto, maior a informação;

3. Se uma escolha for dividida em uma série de escolhas sucessivas, a informação original deve ser a média ponderada das informações individuais. Isto é ilustrado na figura abaixo:

Figura 2 - Decomposição de uma escolha com três possibilidades
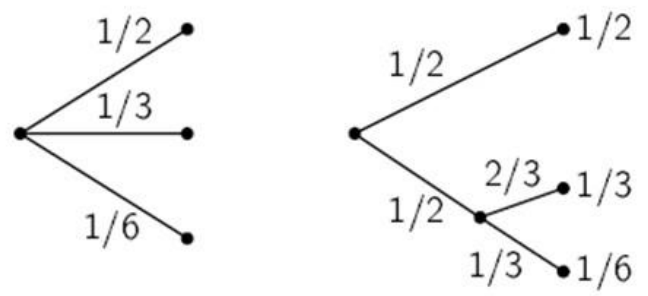

Fonte: SHANNON (1948).

À esquerda existem três possibilidades com probabilidades $1 / 2,1 / 3$ e 1/6. À direita existem primeiramente duas possibilidades, com probabilidades de 1/2 cada. Se a segunda possibilidade for escolhida, existem mais duas possibilidades, com probabilidades $2 / 3$ e 1/3. O resultado final são as mesmas probabilidades do sistema da esquerda. Assim:

$$
H\left(\frac{1}{2}, \frac{1}{3}, \frac{1}{6}\right)=H\left(\frac{1}{2}, \frac{1}{2}\right)+\frac{1}{2} H\left(\frac{2}{3}, \frac{1}{3}\right)
$$


Desta forma, Shannon (1948) demonstra que a única função que satisfaz estas condições é:

$$
H=-K \sum_{i=1}^{N} p_{i} \ln p_{i}
$$

Sendo K uma constante arbitrária (para escolha da unidade de medida).

Ainda de acordo com o autor, a escolha da base do logaritmo depende da escolha da unidade de medida da informação. A escolha da base 2, por exemplo, resulta em unidades chamadas de bits, ou binary digits, assim como a base 10 gera decimal digits. Por fim, para trabalhos analíticos envolvendo integração e diferenciação, Shannon (1948) recomenda o uso da base $e$, resultando em natural units.

Weaver (1964) analisa o comportamento da medida de entropia desenvolvida por Shannon (1948). Para escolhas entre duas mensagens possíveis, cujas probabilidades de ocorrência são $p_{1}$ e $p_{2}=1-p_{1}, H$ (conforme definido acima) tem o maior valor possível quando as duas mensagens são igualmente prováveis, ou seja, quando $p_{1}=p_{2}=1 / 2$, existe total liberdade de escolha entre as duas. Logo que uma mensagem se torna mais provável que a outra ( $p_{1}$ maior que $p_{2}$, por exemplo), o valor da entropia $(H)$ diminui. E quando uma mensagem é muito provável ( $p_{1}$ quase igual a 1 e $p_{2}$ quase 0 , por exemplo), o valor de $H$ é muito pequeno (quase nulo). No limite, quando uma probabilidade é unitária (certeza de ocorrência) e as outras são iguais a 0 (impossibilidade de ocorrência), $H$ é nula (não há incerteza, logo não há liberdade de escolha, não há informação).

\subsection{Entropias Condicionais e Previsibilidade}

A entropia é uma medida muito importante para a Teoria da Informação, já que ela mede quão incerto é um determinado estado de um sistema físico. Suponha que o valor da variável aleatória $X$ é sabido. A Entropia de Shannon mede quanta informação se ganha, em média, quando se descobre o valor de $X$. Ou, sob outro ponto de vista, a entropia de $\mathrm{X}$ mede a incerteza sobre $\mathrm{X}$ que existia previamente ao 
conhecimento de seu valor. Ou seja, a entropia pode ser vista como a incerteza antes da informação, ou o conhecimento adquirido (NIELSEN E CHUANG, 2016).

Desta forma, a medida de entropia também está intimamente ligada à previsibilidade. De acordo com Ebeling et al (2002), para se medir a previsibilidade de séries temporais, primeiramente admite-se que estas sigam uma trajetória em espaços de estado discretos, de tamanho total $L$. Define-se $\lambda$ como o tamanho total do alfabeto. Dentro da trajetória $L$, pode-se destacar uma sub-trajetória qualquer, de tamanho $n \leq L$, formada pelas letras $A_{1}, A_{2}, \ldots, A_{n}$. Desta forma, $p^{(n)}\left(A_{1}, \ldots, A_{n}\right)$ seria a probabilidade de se encontrar, na trajetória inteira, um intervalo (sub-trajetória) com estas letras $\left(A_{1}, \ldots, A_{n}\right)$. Assim, temos a entropia por intervalo (de tamanho $n$ ):

$$
H_{n}=-\sum p^{(n)}\left(A_{1}, \ldots, A_{n}\right) \log p^{(n)}\left(A_{1}, \ldots, A_{n}\right)
$$

Por meio das entropias nos intervalos, deriva-se a entropia condicional (dinâmica):

$$
h_{n}=H_{n+1}-H_{n}
$$

Define-se então $r_{n}=1-H_{n}$ como a previsibilidade média de um estado imediatamente após uma dada $n$-trajetória. Assim, pode-se mostrar que a previsibilidade de um processo está intimamente ligada às entropias condicionais. Estas são as chamadas entropias $n$-grama. O limite deste valor, para $n$ suficientemente grande, é a entropia da fonte, ou entropia de Kolmogorov-Sinai.

Assim, dada uma série temporal, pode-se calcular a previsibilidade do estado que vem em seguida à sub-trajetória de tamanho $n$ :

$$
h_{n}^{(1)}\left(A_{1}, \ldots, A_{n}\right)=\sum p\left(A_{n+1} \mid A_{1}, \ldots, A_{n}\right) \log p\left(A_{n+1} \mid A_{1}, \ldots, A_{n}\right)^{-1}
$$

Desta forma, $h_{n}^{(1)}$ é a incerteza do próximo estado (um passo à frente) ao estado que vem após a trajetória $A_{1}, \ldots, A_{n}$. Aqui, e nas equações que se seguem, todos os logaritmos são medidos em $\lambda$ unidades, para as quais a seguinte desigualdade é válida:

$$
0 \leq h_{n}^{(1)}\left(A_{1}, \ldots, A_{n}\right) \leq 1
$$


Define-se então

$$
r_{n}^{(1)}\left(A_{1}, \ldots, A_{n}\right)=1-h_{n}^{(1)}\left(A_{1}, \ldots, A_{n}\right)
$$

como a previsibilidade do próximo estado depois de uma dada sub-trajetória, observando que $0<r_{n}^{(1)}\left(A_{1}, \ldots, A_{n}\right)<1$.

Por fim, a média da incerteza local traz de volta a entropia $n$-grama de Shannon:

$$
h_{n}=h_{n}^{(1)}=\left\langle h_{n}^{(1)}\left(A_{1}, \ldots, A_{n}\right)\right\rangle=\sum p\left(A_{1}, \ldots, A_{n}\right) h_{n}^{(1)}\left(A_{1}, \ldots, A_{n}\right)
$$

Para generalizar, pode-se calcular a previsibilidade de um estado não imediatamente após a $n$ - sub-trajetória, mas $\operatorname{sim} k$ passos à frente:

$$
h_{n}^{(k)}\left(A_{1}, \ldots, A_{n}\right)=\sum p\left(A_{n+k} \mid A_{1}, \ldots, A_{n}\right) \log p\left(A_{n+k} \mid A_{1}, \ldots, A_{n}\right)^{-1}
$$

E as previsibilidades locais:

$$
r_{n}^{(k)}\left(A_{1}, \ldots, A_{n}\right)=1-h_{n}^{(k)}\left(A_{1}, \ldots, A_{n}\right)
$$

Para $n=1$ a previsibilidade média está intimamente ligada à informação mútua, que pode ser expressa por meio das medidas de previsibilidade:

$$
I(k)=r_{1}^{k}-r_{0}
$$

onde $r_{0}=1-H_{1}$ é a previsibilidade de um estado no qual não existe informação prévia.

Vale destacar que, para sistemas de memória longa, é interessante estudar a série inteira de previsibilidades com $n$ - séries crescentes

$$
r_{1}^{(k)}, r_{2}^{(k)}, r_{3}^{(k)}, \ldots, r_{m}^{(k)}
$$

onde $m$ é uma estimativa para o tamanho da memória. Como $r_{n+1}^{(k)} \geq r_{n}^{(k)}$, a previsibilidade média irá aumentar usando-se intervalos mais longos. Ou seja, é vantajoso basear-se em previsões não apenas dos estados atuais, e sim em intervalos na trajetória inteira, que representam o estado atual e sua história.

Assim, a informação mútua pode ser definida como: 


$$
I(n)=\sum p^{(n)}\left(A_{i}, A_{j}\right) \log \left[\frac{p^{(n)}\left(A_{i}, A_{j}\right)}{p^{(1)}\left(A_{i}\right) p^{(1)}\left(A_{j}\right)}\right]
$$

onde $I(0)=H_{1}$ e $I(-n)=I(n)$.

Pode-se observar que a informação mútua é uma medida especial de correlação, muito semelhante à função de autocorrelação. A relação entre entropias e previsibilidade e informação mútua é de extrema importância para a Teoria da Comunicação, na medida em que a previsibilidade de uma letra (estado), $n$ passos à frente é a soma da informação mútua e da previsibilidade geral das letras $r_{0}=1-$ $H_{1}$. Como mostrado por vários autores, a informação mútua é uma medida confiável para as correlações entre as letras numa distância $n$. Todos os picos (de informação mútua) em $n$ correspondem a uma forte correlação positiva (EBELING et al., 2002).

\subsection{Complexidade}

Kolmogorov e Sinai, em 1959, foram os primeiros a aplicar o estudo de Shannon a processos dinâmicos, fazendo com que o conceito de entropia passasse a integrar a moderna teoria dos sistemas dinâmicos. Alguns anos depois, Kolmogorov desenvolveu a caracterização da complexidade de sequências. Assim, entropia e complexidade desempenham papel fundamental no estudo de séries de tempo irregulares, sendo de grande importância em vários campos das ciências.

Séries de tempo reais são normalmente muito diferentes das simuladas em laboratórios. Elas podem ser curtas, com ruídos, irregularmente distribuídas e, acima de tudo, não estacionárias. Para modelar o comportamento destes tipos de sistemas, é necessário investigar se os dados apresentam alguma estrutura, por exemplo, correlações; e que tipo de estrutura seria. A medida de complexidade é bem apropriada a estes casos (EBELING et al., 2002).

O conceito de complexidade está associado a fenômenos de ordem não sabida, que, de certa forma, possuem algum grau de aleatoriedade. A complexidade pode ser definida como a linha de fronteira entre desordem e ordem em um sistema. Formalmente, isto implica que complexidade é uma função convexa da desordem. 
De forma geral, a definição de desordem é baseada na comparação da entropia de Boltzman-Gibbs-Shannon, $H$, com a entropia máxima do sistema, $H^{\text {max }}$. No caso mais simples, com $N$ estados equiprováveis, a máxima entropia é atingida em:

$$
H^{\max }=\log _{2} N
$$

É importante notar que a entropia de Shannon é uma medida de aleatoriedade, ou seja, a complexidade é mais alta para comportamentos semelhantes ao ruído branco, quando passado e futuro são não correlacionados. Às medidas de complexidade que possuem esta característica chama-se de medidas tradicionais de complexidade.

Para Shiner, Davidson e Landsberg (1999), as definições de Complexidade podem ser divididas em três categorias. Primeiramente têm-se as medidas de Complexidade que são funções monotonicamente crescentes da desordem (representadas no gráfico I da figura abaixo). Outras medidas são funções convexas da desordem: a complexidade é mínima para os sistemas nos extremos (completamente ordenados ou completamente desordenados) e máxima nos níveis intermediários (gráfico II). Por fim, existem definições que são similares a medida de ordem do sistema, identificam Complexidade com o nível de organização do sistema (gráfico III).

Figura 3 - As três categorias de Complexidade como função da desordem
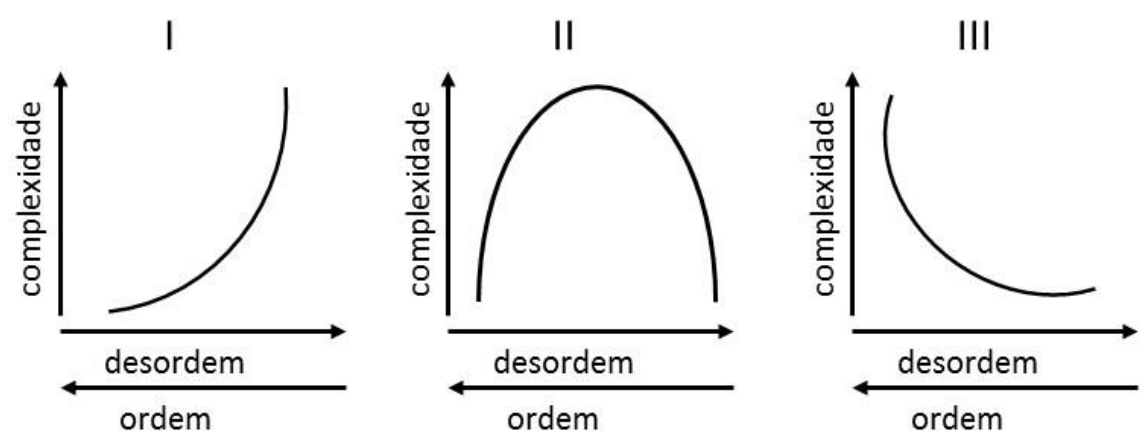

Fonte: SHINER, DAVIDSON e LANDSBERG (1999). 
Segundo os autores, a medida de Complexidade por eles desenvolvida (conhecida como Complexidade SDL), pode apresentar os três comportamentos descritos acima, dependendo apenas da escolha dos parâmetros. Eles definem a própria medida como uma generalização da Complexidade LMC, desenvolvida por Lopez, Mancini e Calbet (1995). Ambas as medidas são objeto deste estudo, e são a seguir definidas. Ao final, são aplicadas às séries financeiras brasileiras e seus resultados são comparados.

\subsubsection{Complexidade LMC}

Lopez, Mancini e Calbet (1995) definem complexo como algo (objeto, procedimento ou sistema) que não se encaixa nos padrões definidos como simples. A noção de complexidade na Física, segundo os autores, pode ser bem exemplificada por meio dos modelos de um cristal perfeito e um gás ideal isolado. Um cristal perfeito é completamente ordenado, e seus átomos estão distribuídos de forma totalmente simétrica. Apenas uma pequena quantidade de informação é necessária para descrever o seu sistema, ou seja, a informação estocada neste é mínima. Já o gás ideal isolado é totalmente desordenado. Este sistema pode ser encontrado em qualquer um dos seus estados possíveis, com a mesma probabilidade. Ou seja, cada estado contribui de forma igual para a informação contida no sistema, sua informação estocada é máxima. Em resumo, a medida de complexidade está associada à distância da distribuição equiprovável dos possíveis estados do sistema: o desequilíbrio é diferente de zero quando existem estados mais prováveis que os outros. 
Figura 4 - Complexidade como função da Informação e Desequilíbrio, para o cristal e o gás ideal

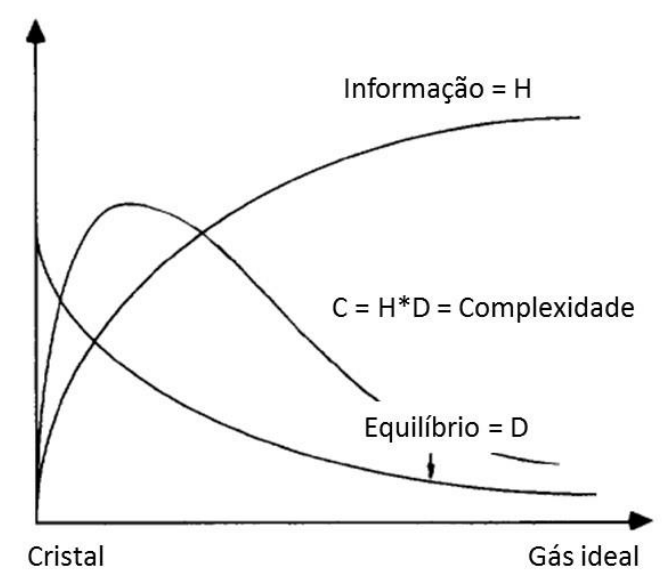

Fonte: LOPEZ, MANCINI e CALBET (1995).

A informação máxima pode ser acessada por meio da medida de entropia de Shannon em um sistema com $N$ estados acessíveis:

$$
H=-K \sum_{i=1}^{N} p_{i} \log p_{i}
$$

onde $K$ é uma constante real e positiva, e $p_{i}$ são as probabilidades associadas, sendo $\sum_{i=1}^{N} p_{i}=1$. Um sistema isolado em equilíbrio apresenta equiprobabilidade:

$$
p_{i}=1 / N
$$

para todo i contido em seus estados acessíveis. Nesta situação, alcança-se a entropia máxima:

$$
H_{\max }=K \log N
$$

Porém, se o sistema está fora do equilíbrio, a medida de entropia pode ser expandida (por meio da expansão de Taylor) entorno da entropia máxima $H_{\text {max }}$ :

$$
H\left(p_{1}, p_{2}, \ldots p_{N}\right)=K \log N-\frac{N K}{2} \sum_{i=1}^{N}\left(p_{i}-\frac{1}{N}\right)^{2}+\cdots=H_{\max }-\frac{N K}{2} D+\cdots
$$

onde a quantidade $D=\sum_{i}\left(p_{i}-1 / N\right)^{2}$, chamada desequilíbrio, é uma medida de distância do equilíbrio. Multiplicando a equação acima por $H$, tem-se: 


$$
H^{2}=H * H_{\max }-\frac{N K}{2} H * D+K^{2} f\left(N, p_{i}\right)
$$

sendo $f\left(N, p_{i}\right)$ a entropia multiplicada pelos outros termos da expansão de Taylor, que representam $\frac{1}{N} \sum_{i}\left(N p_{i}-1\right)^{m}$, com $m>2$. Fazendo $C=H * D$ :

$$
C=\text { cte. } * H *\left(H_{\max }-H\right)+K f^{\prime}\left(N, p_{i}\right)
$$

onde $c t e .^{-1}=N K / 2$ e $f^{\prime}=2 f / N$. Assim, a ideia de distância para medir o desequilíbrio fica clara.

Desta forma, LMC definem o desequilíbrio de um $\mathrm{N}$-sistema como as distâncias quadráticas de cada estado em relação a equiprobabilidade:

$$
D=\sum_{i=1}^{N}\left(p_{i}-1 / N\right)^{2}
$$

Nos dois extremos, o cristal apresenta máximo desequilíbrio (no estado dominante $\mathrm{p} \sim 1, \mathrm{D} \rightarrow 1$ para $\mathrm{N} \rightarrow \infty$ ) enquanto que para o gás ideal o desequilíbrio é próximo de zero (D 0) por construção.

Por fim, a Complexidade LMC é simplesmente a combinação da informação estocada no sistema com o seu desequilíbrio:

$$
C_{L M C}=H * D=-\left(K \sum_{i=1}^{N} p_{i} \log p_{i}\right)\left(\sum_{i=1}^{N}\left(p_{i}-\frac{1}{N}\right)^{2}\right)
$$

É interessante observar que, apesar de o cristal e o gás ideal estarem em extremos opostos em termos de desordem (ou desequilíbrio), ambos estão associados a medidas nulas de complexidade.

\subsubsection{Complexidade SDL}

A medida de Complexidade de Shiner, Davidson e Landsberg (1999) também é uma combinação de ordem e desordem. De acordo com os autores, muitas medidas de desordem assumem que o tamanho do sistema, expresso pelo número de estados disponíveis, não varia com o tempo. Porém, para estas medidas, se o número de estados se torna maior, a desordem e a entropia também aumentam 
automaticamente. Para evitar este problema, os autores propõem uma medida de desordem que leve em consideração o tamanho do sistema:

$$
\Delta \equiv S / S_{\max }
$$

na qual $S$ é a entropia de Boltzman-Gibbs-Shannon:

$$
S \equiv-k \sum_{i=1}^{N} p_{i} \ln p_{i}
$$

onde $p_{i}$ é a probabilidade de ocorrência do estado $i$ dentre os $N$ estados disponíveis no sistema, e ké a constante de Boltzman, apropriada para os sistemas físicos.

No caso mais simples, de um sistema isolado, a entropia máxima ocorre com a distribuição equiprovável dos estados, $p_{i}=1 / N, 1 \leq i \leq N$, de forma que:

$$
S_{\max }=k \ln N
$$

é a maior entropia possível.

A ordem do sistema, por sua vez, é definida como:

$$
\Omega \equiv 1-\Delta
$$

Assim, os valores possíveis de ordem e desordem estão entre 0 e 1, e são independentes do tamanho do sistema. Desta forma, é possível que entropia e ordem aumentem juntas em decorrência de um aumento de tamanho do sistema.

Finalmente, combinando as medidas de ordem e desordem previamente definidas, pode-se chegar a uma medida de complexidade que satisfaça as três categorias descritas nas páginas anteriores:

$$
\Gamma_{\alpha \beta} \equiv \Delta^{\alpha} * \Omega^{\beta}=\Delta^{\alpha} *(1-\Delta)^{\beta}=\Omega^{\beta} *(1-\Omega)^{\alpha}
$$

Traduzindo para a nomenclatura utilizada neste estudo, onde a entropia de Shannon é denominada de $H$ :

$$
\mathrm{C}_{S D L}=\left(1-H / H^{\max }\right)^{\beta}\left(H / H^{\max }\right)^{\alpha}
$$

Em termos das categorias de medidas de complexidade previamente citadas, pode-se demonstrar que, quando $\alpha>0$ e $\beta$ é muito pequeno, a complexidade é uma função crescente da desordem, como descrito na categoria I (da Figura 3). Ao contrário, quando $\beta>0$ e a é muito pequeno, a complexidade é uma função crescente 
da ordem, de acordo com a categoria III. Por fim, quando $\alpha>0$ e $\beta>0$, a complexidade atinge valores mínimos em ambos os extremos, em sistemas que tenham ordem zero ou desordem zero.

Vale destacar que ambas as medidas (SDL e LMC) relacionam complexidade zero para comportamentos aleatórios, ou seja, quanto menor a complexidade, mais próximo de um ruído branco está o comportamento da série.

\subsection{Aplicação da Teoria da Informação aos Mercados Financeiros}

Os métodos lineares clássicos geralmente falham em fornecer (com alto grau de confiança) a previsibilidade de séries temporais que contenham ruídos fortes; a previsibilidade pode não ser constante, apresentando-se mais alta para eventos mais raros. Nestes casos, os conceitos de entropia, complexidade e previsibilidade local, em combinação com os métodos clássicos, podem apresentar resultados mais confiáveis.

Ebeling et al. (2002) aplicaram estes conceitos à série histórica do índice de ações norte-americano Dow Jones, de 1900 a 1999 - uma amostra de 27.044 observações.

Observando que o índice apresenta uma tendência de crescimento exponencial, foram usados os retornos logarítmicos diários:

$$
x_{t}=\ln \left(S_{t}\right)-\ln \left(S_{t-1}\right)
$$

A série real de $x_{t}$ foi partida em símbolos $A_{t}$ de um alfabeto de tamanho $\lambda$. Encontrar a partição ótima é um processo de maximização da entropia de Kolmogorov-Sinai, porém, segundo os autores, para séries com forte ruído e memória curta, a partição em porções de frequências iguais aproxima o ótimo. Desta forma, foi escolhido $\lambda=3$ : para $x_{t}<-0,0025$ (forte queda nos preços das ações), $A_{t}=0$; para $x_{t}>0,0034$ (forte alta) $A_{t}=2$; e $A_{t}=1$ para $-0,0025>x_{t}>0,0034$ (estado intermediário). 
Foram calculadas as incertezas locais $h_{n}\left(A_{1}, \ldots, A_{n}\right)$ para o dia seguinte a uma série de $n$ dias (de pregão) $A_{1}, \ldots, A_{n}$. Para $n=5$, os autores encontraram que a incerteza é quase unitária, ou seja, a previsibilidade local é muito baixa. Porém, segundo constataram, atrás de certos padrões de movimento dos preços das ações, a previsibilidade local alcançou $8 \%$, um valor notável em termos de mercado financeiro, cujos movimentos de preços costumam se aproximar da total aleatoriedade. A média de previsibilidade calculada para a série inteira foi de aproximadamente $2 \%$.

Para testar a significância da previsibilidade calculada, os autores montaram a função distribuição da incerteza local $h_{n}^{s}\left(A_{1}, \ldots, A_{n}\right)$. O nível de significância $k$ é calculado como:

$$
k_{n}\left(A_{1}, \ldots, A_{n}\right)=\frac{h_{n}\left(A_{1}, \ldots, A_{n}\right)-\left\langle h_{n}^{S}\left(A_{1}, \ldots, A_{n}\right)\right\rangle}{\sigma}
$$

onde $h_{n}^{s}\left(A_{1}, \ldots, A_{n}\right)$ é a média e $\sigma$ é o desvio-padrão da distribuição da incerteza local.

Assumindo uma distribuição Gaussiana, $|k| \leq 2$ representa um nível de confiança maior que $95 \%$. Porém, os autores observam que a distribuição de incerteza está mais próxima a uma exponencial, o que requer níveis mais altos de $k$. Mas, conforme observaram, felizmente as previsibilidades locais mais altas estão associadas a altos níveis de significância. Por fim, vale lembrar que a série original foi dividida em pequenos pedaços, para corrigir o problema da não-estacionariedade característico de séries longas.

Bentes e Menezes (2012) sugerem o uso da Entropia como a nova medida de volatilidade para os mercados de ações. Argumentam que, em tempos de incerteza, entender a volatilidade dos mercados é crucial. Neste contexto, a volatilidade é normalmente usada para descrever a dispersão em relação a um valor esperado, preço ou modelo. Assim, o desvio-padrão é a medida popularmente usada para quantificar incerteza, ou risco, já que é facilmente calculável. Porém, seus resultados muitas vezes não são satisfatórios, já que são severamente afetados por valores extremos. Nestes casos, a Entropia pode ser uma boa alternativa, como medida de desordem, distância ao equilíbrio, ou até mesmo ignorância; como estudos da Econofísica atualmente têm revelado. 
Para testar a Entropia como medida de volatilidade, os autores aplicam as medidas de Entropia de Shannon e Tsallis ${ }^{4}$ aos índices de ações dos principais mercados do mundo: FTSE 100 (Reino Unido), SP 500 (Estados Unidos da América), CAC 40 (França), MIB 30 (Itália), NIKKEI 225 (Japão), IBEX 35 (Espanha) e PSI 20 (Portugal). Os resultados de ambas as medidas atestam a presença de dinâmica não linear na volatilidade de todos os índices, diferentemente das estatísticas produzidas pela simples medida de desvio-padrão, o que revela que esta última não é capaz de capturar o comportamento da dispersão destes dados em sua totalidade. Bentes e Menezes (2012) concluem então que a Entropia é uma boa alternativa ao desviopadrão, já que é capaz de capturar a incerteza e desordem presentes em certas séries temporais sem impor nenhuma restrição à distribuição de probabilidade dos dados, o que representa uma grande vantagem.

De forma geral, o conceito de Entropia parece bem difundido entre os mercados financeiros. Zhou, Cai e Tong (2013) fazem um resumo do uso da Entropia como medida de volatilidade, tanto para otimização de portfólios como para a precificação de ativos financeiros, especialmente derivativos.

Segundo os autores, o modelo de média - variância de Markowitz, amplamente usado para a seleção de portfólios, muitas vezes implica em portfólios altamente concentrados em poucos ativos, inconsistentes com o objetivo principal de diversificação do risco e maximização do retorno. Este modelo baseia-se na hipótese de distribuição normal dos retornos dos ativos financeiros, o que não condiz com a realidade, já que muitas das distribuições reais são assimétricas ou não gaussianas, o que requer uma medida de incerteza mais dinâmica do que a variância. Nestes casos, a entropia pode ser uma boa alternativa como medida de diversificação, especialmente porque não assume nenhuma distribuição específica.

Zhou, Cai e Tong (2013) citam o trabalho de Philippatos e Wilson como pioneiro no uso da Entropia para a seleção de portfólios. O objetivo principal destes autores era maximizar o retorno esperado do portfólio e ao mesmo tempo minimizar sua

\footnotetext{
${ }^{4}$ A Entropia de Tsallis é uma adaptação da Entropia de Shannon para sistemas nos quais as hipóteses de ergodicidade e independência não são válidas. Esta medida não será aqui detalhada pois foge do escopo deste estudo.
} 
Entropia. Para isso, propuseram o conceito de Entropia individual de cada ativo, utilizando a Entropia de Shannon:

$$
H=-\sum_{i=1}^{n} p_{i} \ln p_{i}
$$

Assim, definem a entropia conjunta para cada par de ativos como:

$$
H\left(R_{1 i}, R_{2 j}\right)=-\sum_{i=1}^{n} \sum_{j=1}^{m} p\left(R_{1 i}, R_{2 j}\right) \log _{2}\left[p\left(R_{1 i}, R_{2 j}\right)\right]
$$

onde $p\left(R_{1 i}, R_{2 j}\right)$ é a probabilidade de o ativo $R_{1}$ estar no estado $i$ e $R_{2}$ estar no estado $j$; e a entropia condicional:

$$
H\left(R_{1 i} \mid R_{2 j}\right)=-\sum_{i=1}^{n} \sum_{j=1}^{m} p\left(R_{1 i} \mid R_{2 j}\right) \log _{2}\left[p\left(R_{1 i} \mid R_{2 j}\right)\right]
$$

onde $p\left(R_{1 i} \mid R_{2 j}\right)$ é a probabilidade de o ativo $R_{2}$ estar no estado $j$ dado que $R_{1}$ está no estado $i$.

Dadas as Entropias individuas, conjuntas e condicionais, a Entropia de um portfólio com um único índice de mercado pode ser definida como:

$$
H\left(R_{1}, R_{2}, R_{3}, R_{I}\right)=H\left(R_{i}\right)+X_{1} H\left(R_{1} \mid R_{I}\right)+X_{2} H\left(R_{2} \mid R_{I}\right)+X_{3} H\left(R_{3} \mid R_{I}\right)
$$

onde $R_{1}, R_{2}, R_{3}$ são os retornos de 3 ativos, $R_{I}$ é o retorno do índice de mercado e $X_{i}$ é a fração do portfólio investida no ativo $i$. Por fim, o risco do portfólio pode ser minimizado por meio da minimização da seguinte função:

$$
H\left(\text { Portfolio } \mid R_{I}\right)=\sum_{i=1}^{3} X_{i} H\left(R_{i} \mid R_{I}\right)
$$

Esta teoria também foi comprovada empiricamente pelos autores, selecionando de maneira aleatória cinquenta ativos da New York Stock Exchange e do Dow Jones Industrial Index, e foi posteriormente utilizada como base para os trabalhos de diversos outros autores.

Zhou, Cai e Tong (2013) também citam o uso da medida de Entropia para a precificação de ativos, especialmente quando há pouca informação disponível para a aferição das distribuições de probabilidades. A Entropia também pode ser muito útil para corrigir falhas de modelos de precificação, como o famoso modelo de precificação de opções de Black e Scholes, que erroneamente assume que a volatilidade dos ativos é constante no tempo. 
Ao contrário da Entropia, a literatura em termos de Complexidade e mercados financeiros ainda é escassa. Piqueira e Mortoza (2012) aplicam o conceito de Complexidade de LMC à série de câmbio dólar-real, de 1999 a 2010. Analisam a evolução temporal desta medida, especialmente diante de eventos de crises políticas e financeiras, nacionais e mundiais.

Para tal, dividem a amostra das taxas diárias de câmbio (de 1999 a 2010) em faixas (ou estados) equidistantes e, por meio da probabilidade de realização de cada estado, chegam às medidas de organização, desorganização e Complexidade do sistema.

Ao final, concluem que a medida é um indicador robusto para crises, tendo em vista os pontos de baixa complexidade coincidentes com eventos que influenciaram a economia brasileira: crise cambial (quando o câmbio brasileiro passou a flutuar, em 1999), ataques terroristas (às Torres Gêmeas em Nova lorque, em setembro de 2001), mudanças políticas (eleição do Presidente Lula, em 2002) e crise financeira (Crise Subprime, em 2008). Importante destacar que pontos de baixa complexidade estão associados a altos níveis de aleatoriedade dos dados. Esta metodologia também é aplicada aqui, e será detalhada mais à frente, na parte empírica deste estudo.

Com o intuito de testar a consistência da medida de Complexidade aplicada aos dados econômicos brasileiros, Mortoza e Piqueira (2017) novamente aplicam a metodologia descrita acima à série de dólar real expandida, testando também uma nova série de dados, o lbovespa - principal índice de ações da Bovespa, a bolsa de valores brasileira. Aqui, não só a Complexidade LMC é testada, a medida de Complexidade de SDL também é aplicada às mesmas séries de dados, e os resultados de ambas as medidas são comparados. Além disso, um novo evento de crise, a reeleição de Dilma Rousseff, é estudado junto aos demais.

Os autores novamente observam que as medidas de Complexidade apresentaram resultados robustos quando aplicadas aos dados macroeconômicos brasileiros, e, portanto, são adequadas para a interpretação dos eventos de crise analisados. Não foram encontradas grandes diferenças qualitativas entre as medidas de Complexidade de LMC e SDL, já que ambas levaram a resultados bastante semelhantes. Observam ainda que a série do Ibovespa aparentemente é mais 
sensível aos cálculos de Complexidade, já que seus resultados apresentaram maior evidencia nos eventos de crise. Concluem, por fim, que a medida de Complexidade pode ser uma importante ferramenta para o diagnóstico de crises em tempo real.

A construção de um indicador que possa diagnosticar crises em tempo real é o grande objetivo deste estudo. Para isso, são usadas as mesmas séries de dados dos estudos citados acima, num horizonte de tempo expandido; e a série de preços do CDS Brasil também é incluída, como proxy para o risco-país. A mesma metodologia é aplicada, acrescida, porém, de nova análise ex ante aos eventos de crises. Os dados utilizados e a metodologia aplicada são explicados no terceiro capítulo deste trabalho, após uma breve descrição do contexto histórico da economia brasileira e dos eventos de crise que aqui são estudados. 


\section{História Econômica do Brasil e Eventos de Crise}

A história econômica do Brasil é bastante rica, especialmente nos últimos 60 anos. O país passou por muitas mudanças políticas, indo da ditadura à democracia; e diversos planos econômicos: alguns ortodoxos, e muitos heterodoxos; e épocas de altíssima inflação. A primeira parte deste capítulo busca resumir os mais importantes acontecimentos políticos e econômicos da história do país, nas décadas precedentes ao período aqui estudado. É dada especial ênfase aos regimes de câmbio pelos quais o país passou, já que o sistema cambial atual é também resultado do desenvolvimento e experimentações do passado. Ibovespa e CDS Brasil têm histórico mais recente, especialmente esse último, e, apesar de não sofrerem grandes mudanças (metodológicas) ao longo do tempo, foram também influenciados por muitos destes eventos.

Em seguida, o pano de fundo do capítulo passa a ser a conjuntura econômica mundial, e são descritos os eventos de crise que abalaram as economias dos diversos continentes, e suas repercussões na economia brasileira. Alguns destes eventos ocorreram apenas em esfera nacional, mas como o Brasil tem uma economia aberta, estes afetaram também o nível de aversão ao risco do investidor estrangeiro.

\subsection{História Econômica do Brasil}

Grande parte da história econômica do Brasil é marcada por períodos de altíssima inflação, e severas crises no Balanço de Pagamentos. Neste cenário, as taxas de câmbio desempenham papel fundamental nas tentativas de estabilização econômica. De forma geral, pode-se dizer que, na maior parte das últimas seis décadas, adotou-se no país o regime cambial de crawling peg; com exceção dos primeiros anos do Governo Militar, marcados por grandes desvalorizações cambiais (BONOMO e TERRA, 1999) e das últimas décadas, quando o câmbio passou a flutuar.

O regime de crawling peg baseia-se em três aspectos essenciais: definição, por parte das autoridades monetárias, de um valor central de referência para a taxa 
de câmbio, com base no seu comportamento num determinado período de tempo anterior; definição de um intervalo (ou banda) de variação entre dois valores de suporte (um superior e outro inferior), centrado no valor central definido; e liberdade de flutuação da taxa de câmbio dentro do intervalo definido pelos valores de suporte.

Segundo constataram Bonomo e Terra (1999), os regimes cambiais apresentam íntima ligação aos ciclos eleitorais pelos quais o Brasil passou nas últimas décadas. Até 1964, ano que marca o início da Ditadura Militar, funcionava no país um sistema de múltiplas taxas de câmbio, implantado em 1953, pela SUMOC (Superintendência de Moeda e de Crédito, autoridade monetária anterior à criação do Banco Central), no contexto do Tratado de Bretton Woods. Naquele ano, as taxas de câmbio foram unificadas e a partir daí, e nos anos seguintes durante o Governo Militar, o regime cambial foi marcado por largas e infrequentes desvalorizações, causando grande variabilidade da taxa de câmbio.

No ano de 1968 teve início um período de mini-desvalorizações na taxa de câmbio nominal, com o objetivo de manter a taxa de câmbio real estável. Nesta época o país experimentou um período de crescimento econômico sem precedentes, que foi chamado de Milagre Econômico. Foi também neste ano que o lbovespa - Índice Bovespa começou a ser compilado.

A metodologia do Índice Bovespa foi criada com o primeiro índice da Bolsa de Valores do Rio de Janeiro, desenvolvido pelo Prof. Mário Henrique Simonsen e equipe em 1962. Em 1966, Luís Sérgio Coelho de Sampaio, Superintendente Técnico, concebeu e implantou várias alterações metodológicas no antigo índice. Em janeiro de 1967 iniciou-se o IBV - Índice da Bolsa de Valores do Rio de Janeiro, cuja metodologia foi adotada pela Bolsa de Valores de São Paulo na implantação do Índice Bovespa em janeiro de 1968. Seu maior objetivo era ser o indicador de desempenho médio das cotações dos ativos de maior negociabilidade e representatividade do mercado de ações brasileiro.

A primeira carteira para o lbovespa abrangia 18 blue chips ${ }^{5}$. Na segunda carteira houve a expansão para 27. Logo em maio de 1971, o índice registrou um pico de cotações com as ações se valorizando, no período de janeiro de 1968 a 1971, 12

\footnotetext{
${ }^{5}$ Ações de empresas de renome no mercado brasileiro.
} 
vezes em termos reais (descontada a inflação conforme IGP-DI da Fundação Getúlio Vargas). Essa época ficou conhecida como "milagre brasileiro". Após a alta, o mercado sofreria com o estouro da bolha especulativa nas Bolsas do Rio de Janeiro e São Paulo, conhecido como "Crash de 1971", com um longo período de declínio das cotações do IBOVESPA, que chegou ao nível mais baixo desse período em janeiro de 1973 (Ibovespa, WIKIPEDIA).

Já ao final deste mesmo ano começava a se delinear a Primeira Crise do Petróleo, na qual o preço do barril praticamente quadruplicou. Neste período, a taxa de câmbio foi mantida constante, e foram aplicadas apenas medidas de restrições às importações. Superada a Crise, o controle da inflação passou a ser prioridade do Governo.

Então, em 1979, tiveram início políticas heterodoxas de controle de preços e, ao final deste mesmo ano, a taxa de câmbio nominal havia sido desvalorizada em $30 \%$, causando também a depreciação da taxa de câmbio real. Para o ano de 1980, a desvalorização da moeda foi predeterminada em $40 \%$, frente a uma taxa de inflação de mais de $77 \%$, com o objetivo de influenciar as expectativas de inflação, cortando a inércia inflacionária.

Durante o ano de 1980 a política heterodoxa de combate à inflação foi sendo abandonada, após comprovada sua total ineficácia, e as políticas ortodoxas foram gradualmente restabelecidas. As antigas mini-desvalorizações foram retomadas, baseadas no diferencial da inflação, o que estabilizou a taxa de câmbio real. Neste período (de 1977 a 1982) o lbovespa flutuou em patamares bem baixos, mais baixos ainda que o "Crash de 1971". A recuperação viria, porém, no ano seguinte.

Em 1982, a recessão mundial somada à moratória do México agravou a situação deficitária do Brasil. As exportações caíram, os pagamentos de juros continuaram crescendo, e as reservas continuaram caindo: o país não teve alternativa senão buscar um acordo com o FMI (Fundo Monetário Internacional). Diante disto, em 1983 o governo foi obrigado a desvalorizar a moeda em 30\%. Após esta maxidesvalorização, o governo continuou seguindo a política de constantes pequenas desvalorizações aplicadas anteriormente. Infelizmente, o que se viu neste período foi mais um ano de acentuada recessão e alto crescimento da taxa de inflação, as taxas anuais ultrapassando as duas casas decimais (alcançando $211 \%$ em 1983). Por outro 
lado, provavelmente a moeda desvalorizada tornou a Bolsa de Valores atrativa, e o lbovespa atingiu um novo boom no ano de 1983, que perduraria por alguns anos mais.

O retorno à democracia, em 1985, foi acompanhado por um longo período de apreciação da taxa de câmbio real. Durante os sete primeiros anos do Governo Democrático o país sofreu cinco tentativas, frustradas, de estabilização econômica.

"Ao final do período havia um relativo consenso entre os economistas de que a indexação no Brasil consistia, sim, num problema a ser solucionado, mas que o congelamento [dos preços] definitivamente não era uma estratégia eficiente" (CASTRO, 2005).

Antes baseado em mini-desvalorizações que acompanhavam a inflação, o regime cambial passa a ser fixo com o lançamento do Plano Cruzado, em 1986. Nesta época, desenvolveu-se o mercado paralelo do dólar, também conhecido como "mercado negro", ou apenas "black". Quando os prêmios do "mercado negro" atingiram a cifra de 90\%, o governo teve que quebrar a regra da taxa de câmbio fixa, e foram retomadas as mini-desvalorizações. Após este, houveram outros planos malsucedidos de combate à inflação: Plano Bresser, Plano Verão, Planos Collor I e II. Nesta época, as desvalorizações cambiais pontuais persistiram.

No mesmo período, o lbovespa se manteve valorizado, seguindo a tendência mundial. Porém, em outubro de 1987, as Bolsas mundiais despencaram dramaticamente no evento que ficou conhecido como "Black Monday". As razões por detrás desta segunda feira negra não são extremamente claras. De acordo com 0 Federal Reserve6 (2006), naquela época, por diversos motivos, os mercados de ações se encontravam inflados, acumulando ganhos além dos fundamentos. Mas o cenário macroeconômico americano já dava sinais de fraqueza, como alto déficit na Balança Comercial, desvalorização do dólar, alta inflação e possíveis aumentos das taxas de juros. Naquela época, os tradings eletrônicos ${ }^{7}$ estavam tornando-se populares, e muitos autores acreditam que este também foi um dos motivos do aumento do pânico nos mercados (EXAME, 2013). Ao final da semana que precedeu ao crash o Índice Dow Jones já acumulava 9\% de queda. Na segunda feira seguinte,

\footnotetext{
${ }^{6}$ Banco Central dos Estados Unidos da América

7 Ordens de compra ou venda de ações ou derivativos executadas automaticamente por um computador
} 
quando o mercado americano abriu, as Bolsas asiáticas já haviam despencado, gerando pânico e forte movimento de venda na Bolsas do mundo inteiro, e este foi acentuado ainda mais com a presença dos trades eletrônicos. Ao final do dia o Dow Jones registrava queda de 22,6\%. A Bolsa Brasileira também sofreu com o crash, acumulando queda de $16,17 \%$ no dia seguinte. Este foi um dos grandes tombos registrados em toda a história do Ibovespa.

Mas a maior queda da história do lbovespa (no intervalo de um dia) aconteceria poucos anos depois, em 1990, durante o Governo Collor. Conforme descrito anteriormente, este foi um período marcado por altas taxas de inflação e tentativas heterodoxas de estabilização. Numa destas tentativas, o Governo já havia praticado o congelamento dos preços, provocando venda generalizada dos ativos financeiros. Ao final de março daquele ano o pessimismo já dominava o mercado, e o lbovespa acumulava queda de 20,95\%. Foi quando, em 21 de março, o Governo decretou o "confisco", ou bloqueio, das cadernetas de poupanças, numa tentativa de retirar liquidez do mercado monetário. Mais uma vez o pânico tomou conta do mercado financeiro, e o lbovespa despencou 22,27\% (EXAME, 2013).

Foi então que, em 1994, foi lançado o Plano Real, que introduziu uma nova moeda cuja cotação inicial estava indexada ao dólar. Porém, no período que se seguiu, o dólar é que estava indexado a esta nova moeda, a URV (Unidade Real de Valor), e o Governo deveria intervir sempre que o valor da primeira moeda ultrapassasse o da segunda; até que a URV se tornou a moeda oficial do país. Esta era uma moeda de transição, que logo deu lugar à nova moeda do país, o Real.

Em seus primeiros meses de vida, o Real acumulou apreciação de quase $20 \%$, o que fez com que, diante da grande pressão dos setores exportadores, o Governo alterasse a política cambial, introduzindo um sistema de bandas cambiais. A moeda sofreu desvalorização de $6 \%$, e poderia flutuar numa banda de $5 \%$ de intervalo, que seria mudada de tempos em tempos. As taxas de câmbio passaram a ficar bastante estáveis, devido principalmente à intervenção do Banco Central por meio de leilões periódicos.

Porém a sustentabilidade da política cambial passou a ser debatida, devido ao déficit em Conta Corrente, que crescia desde 1994. O financiamento deste déficit, que era feito principalmente pelo fluxo de capitais externo, que estava abalado devido à 
perda de confiança causada pela Crise do México, tornou-se cada vez mais escasso. A Crise Asiática de 1997 causou um segundo choque, sendo seguida, em 1998, pela crise da Rússia.

O lbovespa também sofreu choques durante estes anos de crises. Em outubro de 1997, devido à crise asiática, registrou queda de 14,98\% num único dia. Já em 1998, com a moratória da Rússia, o lbovespa sofreu queda de 15,83\% em um dos seus piores dias. Porém nesta época o circuit breaker já havia sido implantado. Este é um mecanismo que interrompe as negociações da Bolsa por 30 minutos diante de movimentos abruptos, impedindo quedas ainda maiores (EXAME, 2013).

O resultado destas crises foi uma depressão das reservas nacionais de moeda estrangeira de aproximadamente 30 bilhões de dólares, usadas para defender nossa moeda frente à desvalorização. A política cambial continuou sofrendo pressão até que, em janeiro de 1999, a situação tornou-se insustentável e a moeda teve que ser deixada livre para flutuar, sofrendo inicialmente grande desvalorização. É neste momento que a amostra de dados aqui utilizada tem início, quando as taxas de câmbio passaram a flutuar livremente - salvo intervenções do Banco Central por meio de leilões - regime que perdura até os dias atuais.

\subsection{Os Eventos de Crise}

Esta seção descreve os acontecimentos econômicos e políticos que causaram mudanças drásticas na taxa de câmbio dólar-real, Ibovespa e CDS Brasil. Pode ser que o título de Crises não seja o mais adequado para esta seção, já que, alguns destes eventos resultaram realmente em crises mundiais, porém muitos foram apenas choques temporários. 


\subsubsection{A Crise Cambial de 1999}

As séries temporais tratadas neste estudo têm início em janeiro de $1999^{8}$, quando acontece o primeiro choque dos que aqui são analisados. Como foi dito na seção anterior, até então o regime cambial do país era composto por bandas administradas. Pode-se dizer que a Crise Cambial Asiática, em 1997, e em seguida o default da Rússia, em 1998, desencadearam a crise brasileira, na medida em que abalaram a confiança do investidor estrangeiro e cessaram o fluxo de capital externo para os países emergentes (ou em desenvolvimento).

Nestas condições, defender a moeda nacional, isto quer dizer, manter a taxa de câmbio dentro das bandas estipuladas, estava cada vez mais difícil, e era feito ao custo da perda de reservas internacionais. Desta forma, e sem a entrada do capital estrangeiro, as contas nacionais externas simplesmente "não fechavam" (AVERBUG e GIAMBIAGI, 2000). As privatizações constituíram um fator mitigador, já que implicavam na entrada de capitais externos. E assim aconteceu em agosto de 1998, quando foi liquidada a primeira parcela de compra da Telebrás, quando as reservas internacionais atingiram a cifra de US $\$ 75$ bilhões. Porém, em apenas 50 dias, o país perdeu mais de US $\$ 30$ bilhões, fato que fez o mês de setembro ficar conhecido como "setembro negro". Neste contexto, a poucas semanas das eleições presidenciais, quando Fernando Henrique Cardoso veio a ser reeleito, foi anunciado novo acordo com o FMI, o que deu ao governo um pequeno tempo para respirar.

O ápice da crise aconteceu quando o Congresso votou contra uma das medidas de austeridade fiscal, exigida pelo FMI, e o Governo recém-eleito de Minas Gerais decretou um default temporário da sua dívida com o Governo Federal. Com isso, em meados de janeiro de 1999, a credibilidade brasileira atingiu níveis baixíssimos, e a depreciação da moeda era iminente.

Nesta época, a perda de reservas alcançara a média de US\$ 1 bilhão ao dia. Em 13 de Janeiro foi anunciada a substituição do presidente do Banco Central e novas bandas cambiais que, na prática, implicavam uma depreciação de aproximadamente $9 \%$. Como já era previsto, a perda de reservas se manteve e, no primeiro dia das

\footnotetext{
${ }^{8}$ Exceção para a série do CDS Brasil que é mais recente.
} 
novas bandas, a cotação chegou imediatamente ao teto. O novo regime durou 48 horas e, em 15 de janeiro, já sem alternativas, o Banco Central finalmente deixou o câmbio flutuar livremente:

"O Brasil assistiu então a um caso de overshooting digno de livro-texto. Antes da mudança cambial, a taxa era de R\$/US\$1,21. No dia 14 de janeiro, estava no teto da banda: $R \$ / U S \$ 1,32$. No final de janeiro, atingiu R\$/US\$1,985 e no início de março - auge da desvalorização chegou a R\$/US\$2,16" (AVERBUG e GIAMBIAGI, 2000).

Normalmente o lbovespa e o câmbio andam em direções contrárias, a correlação negativa entre as séries é facilmente detectada, e as razões para isso serão explicadas no capítulo seguinte, quando os dados deste estudo são descritos. Porém a Crise Cambial de 1999 foi uma exceção à regra: a desvalorização cambial incorrida neste período foi benéfica para o desempenho da bolsa brasileira. O Gráfico 1 abaixo mostra o desenvolvimento destes dois indicadores durante o mês de janeiro de 1999.

"Naquele momento, os agentes de mercado entenderam que a economia brasileira vinha apresentando um ritmo de crescimento aquém de seu potencial devido ao câmbio apreciado ${ }^{9}$ e aos elevados juros praticados para atrair recursos externos. Em apenas um mês (janeiro/99), o lbovespa avançou 20,4\%" (ROCHA, 2011).

9 O câmbio era mantido artificialmente apreciado até o momento que ficou livre para flutuar. 
Gráfico 1 - Série histórica do câmbio e lbovespa durante janeiro de 1999

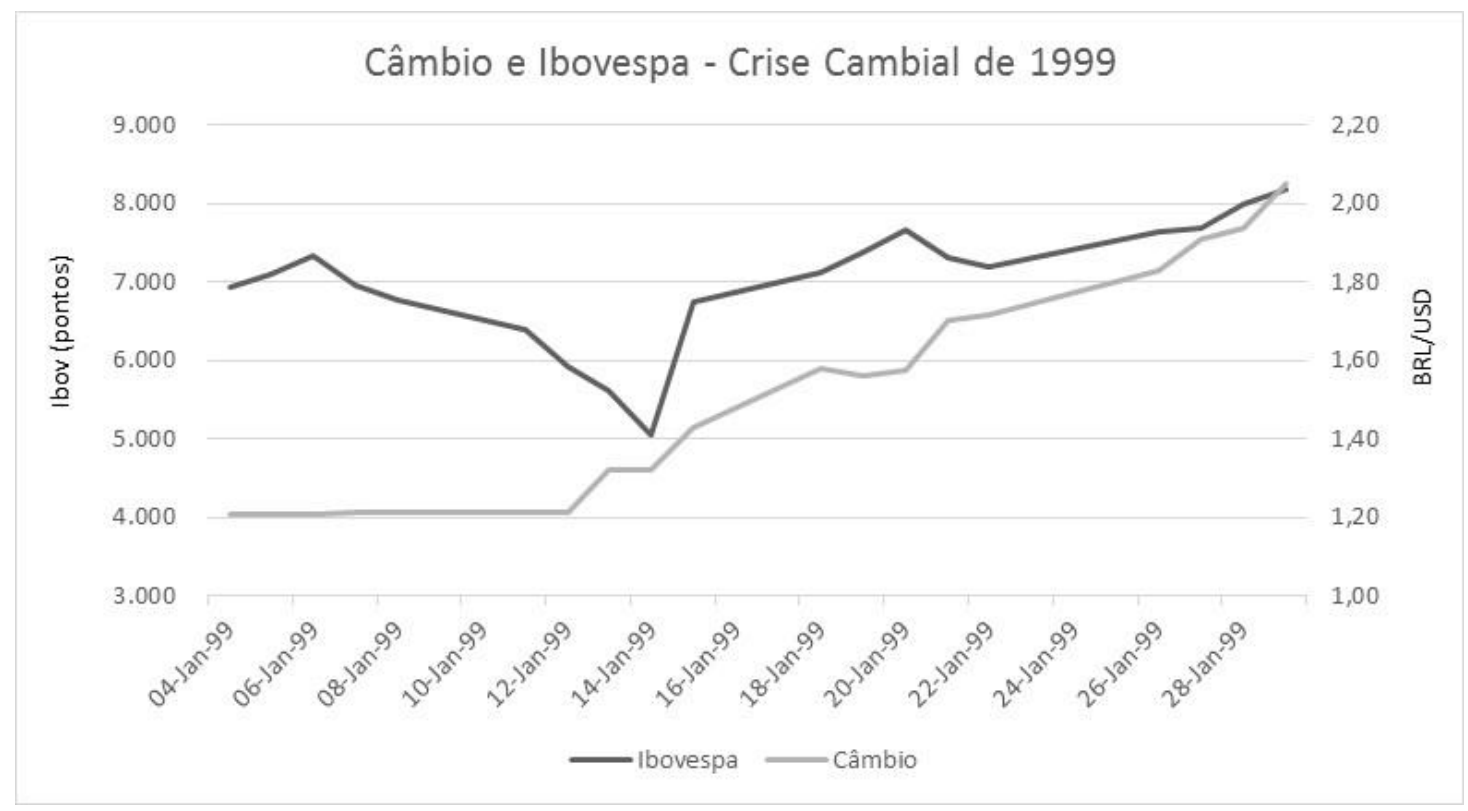

Fonte: elaborado pela autora.

\subsubsection{O Ataque Terrorista às Torres Gêmeas (2001)}

Em 11 de setembro de 2001 os Estados Unidos (EUA) sofreram uma série de ataques suicidas coordenados pela Al-Qaeda, grupo terrorista islâmico. Naquela manhã, 19 terroristas sequestraram e bateram intencionalmente 2 aviões comerciais contra as Torres Gêmeas do World Trade Center, centro comercial e financeiro de Nova lorque, e um terceiro contra o Pentágono, sede do Departamento de Defesa dos EUA, nos arredores de Washington D.C. Em menos de duas horas os prédios na Lower Manhattan foram ao chão, matando mais de três mil pessoas, destruindo construções vizinhas e causando outros danos, especialmente o fechamento de parte do mercado financeiro americano.

As bolsas americanas New York Stock Exchange, American Stock Exchange e NASDAQ não abriram em 11 de setembro, e permaneceram fechadas a semana inteira, até 17 de setembro. Quando finalmente os mercados reabriram, o Dow Jones, principal índice americano de ações, caiu 684 pontos, ou 7,1\%, acumulando queda de mais de $14 \%$ na semana (Chicago Tribune, 2001). Esta foi a segunda maior queda 
do índice em uma semana, superada apenas pelo evento da Crise Subprime, em 2008.

Como qualquer outro choque, os ataques de 11 de setembro causaram aumento da aversão ao risco dos investidores estrangeiros, que acabam sacando parte de seus recursos investidos em países emergentes. Este fato fez com que o dólar sofresse apreciação de mais de 8,6\% em 10 dias (indo de $R \$ 2,60$ em 10/09 a $\mathrm{R} \$ 2,83$ em 21/09).

O lbovespa, como se poderia esperar, também sofreu dramática depreciação, seguindo o movimento de queda geral nas Bolsas do mundo inteiro. Naquela terçafeira (11 de setembro de 2001), o lbovespa despencou 9,18\% (EXAME, 2013). No dia seguinte chegou a esboçar alguma reação, fechando em leve alta, porém despencou novamente nos dias seguintes, acumulando queda de $12,61 \%$ em pouco mais de 10 dias (valor de fechamento de 21/09 comparado ao valor de fechamento de 10/09). Os movimentos do câmbio e do Ibovespa são ilustrados no Gráfico 2 a seguir, no período de agosto a outubro de 2001.

Gráfico 2 - Série histórica do câmbio e lbovespa durante agosto, setembro e outubro de 2001

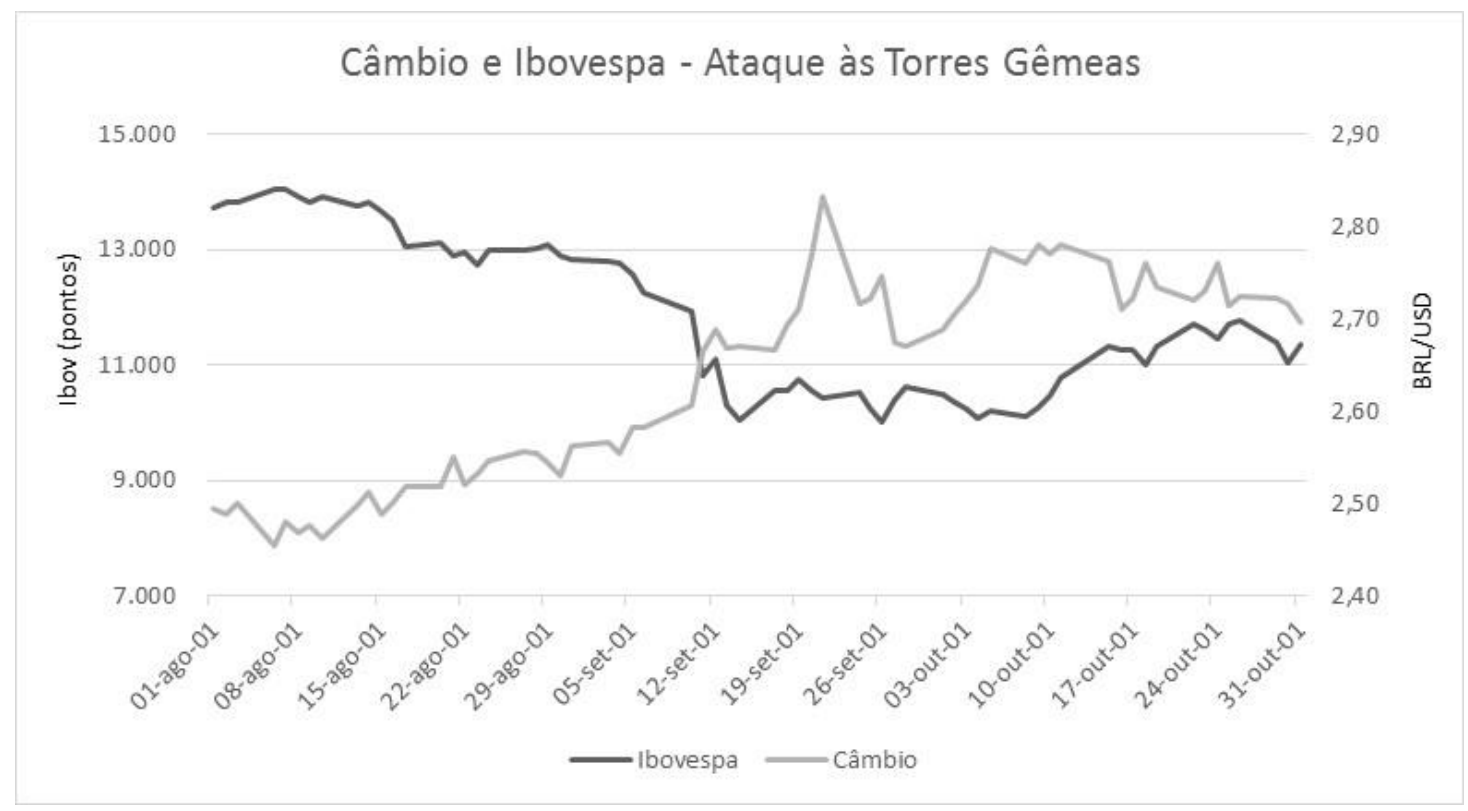

Fonte: elaborado pela autora. 
Porém, conforme constataram Cespedes e Dussold (2004), este terrível evento terrorista não acarretou efeitos de longo prazo aos mercados financeiros. Assim como observado na Bolsa Brasileira, as maiores quedas ocorreram no dia do evento, ou no dia seguinte, dependendo da localização geográfica dos mercados. Segundo os autores, o tempo de recuperação (volta aos patamares pré-ataque) do mercado mundial como um todo foi em média 30 dias. Em termos regionais, os mercados europeus apresentaram o menor período de recuperação, e a América Latina e Canadá apresentaram os períodos mais longos, revelando maior sensibilidade à economia norte-americana.

Um relatório do Congresso Americano a respeito das consequências econômicas dos ataques resume bem a situação:

"Thus far, it would appear that apart from an initial adverse reaction, the short run effects of 9/11 have not been great on foreign economies" (MAKINEN, 2002).

\subsubsection{A Crise Pré-Eleição do Lula (2002)}

Ao final de 2001, após as Crises da Ásia, do México e até do Brasil, quando a moeda começou a flutuar, a confiança do investidor estrangeiro nas economias emergentes estava abalada, e o grau mundial de aversão ao risco estava cada vez mais alto. A esta altura, no início do ano de 2002, a Argentina, que já vinha enfrentando uma recessão econômica desde 1998, além de instabilidade política, desvalorizou sua moeda, abandonando a paridade ao dólar norte-americano introduzida em 1991. Não sendo suficiente, diante do constante crescimento da relação Dívida Pública / Produto Interno Bruto (PIB), o país se viu obrigado a decretar o default de sua dívida. E este foi mais um fato que comprometeu seriamente a confiança do investidor.

Nesta época, o Brasil tinha atingido certa estabilidade, melhorando muito seu arcabouço institucional, especialmente com a criação do Plano de Estabilização Fiscal $^{10}$ em 1998, e da Lei de Responsabilidade Fiscal em 2000, que deram maior

\footnotetext{
10 Lei que governa os gastos dos Governos Estaduais, estabelecendo limites para a dívida pública, e gastos com folha de pagamentos, além de definir metas fiscais anuais para os três anos seguintes
} 
transparência à administração pública. Além disso, a macroeconomia do país já se beneficiava da Política de Metas de Inflação, que acarretou em taxas de inflação controladas, apesar da corrente desvalorização cambial. Porém, nada disso foi suficiente para evitar uma nova crise quando, próximo às eleições presidenciais, 0 candidato de esquerda, Luiz Inácio Lula da Silva, passou a liderar as pesquisas de intenção de voto.

O FMI ${ }^{11}$ e vários economistas de renome da época apontaram que as eleições de outubro de 2002 eram a principal fonte da instabilidade econômica:

\begin{abstract}
"Brazil has implemented strong and consistent macroeconomic policies in recent years that have improved fundamentals. Increases in the public sector primary surplus and the strengthening of fiscal institutions, along with the successful transition to a floating exchange rate regime and inflation targeting have laid the foundation for sustainable growth with price stability. Despite these achievements, the uncertain international economic environment and some concerns about the course of economic policies following the upcoming presidential elections have put substantial pressure on financial variables, including the exchange rate and interest rates, and economic growth has slowed in recent months" (INTERNATIONAL MONETARY FUND, 2002).
\end{abstract}

Desta forma, a grande fuga do capital estrangeiro do país na época é explicada especialmente como resultado, entre outros fatores, da preocupação do investidor estrangeiro quanto a uma mudança radical nas políticas econômicas do país, dada a provável vitória de Lula nas eleições presidenciais que se aproximavam. Lula, além de ser o candidato de um partido de esquerda, tinha dado declarações, em um passado não muito longínquo, de repúdio ao débito externo, especialmente aos financiamentos do FMI, que haviam "socorrido" o país em crises anteriores.

Neste cenário, o risco-Brasil disparou. De acordo com o Banco Central do Brasil (2016), o risco-Brasil é um conceito que busca expressar de forma objetiva o risco de crédito a que os investidores estão submetidos quando investem no país. No mercado, os indicadores diários mais utilizados para esta finalidade são o $E M B I+{ }^{12}$ BR e o $C^{13}$ do Brasil (BANCO CENTRAL DO BRASIL, 2016).

\footnotetext{
${ }^{11}$ Fundo Monetário Internacional (International Monetary Fund)

12 Emerging Markets Bond Index Plus

${ }^{13}$ Credit Default Swap
} 
O $E M B I+$ é um índice compilado diariamente pelo Banco de Investimentos JP Morgan Chase por meio da média ponderada ${ }^{14}$ de instrumentos de dívida externa (normalmente títulos públicos) de países emergentes ativamente negociados e denominados em dólares. Seu cálculo reflete o movimento dos preços dos títulos que o compõem e é dado pela média ponderada dos retornos diários pagos por estes títulos aplicada ao índice do dia anterior. A variação do índice entre duas datas equivale ao rendimento da carteira no período. Para a maioria das carteiras a data base (número índice igual a 100) é 31/12/1993, quando foi iniciado o cálculo deste índice.

O JP Morgan Chase também calcula o EMBI+ separadamente para cada país integrante do índice. Desta forma, o $E M B I+$ para o Brasil recebe o nome de EMBI+ $B R$ e corresponde à média ponderada dos prêmios (spreads) pagos pelos títulos da dívida externa brasileira em relação aos papéis de mesmo prazo do Tesouro dos Estados Unidos. O mercado usa o spread do $E M B I+B R$ para medir a capacidade do país de honrar os seus compromissos financeiros com o exterior, ou seja, quanto maior a pontuação do indicador de risco, maior é o risco de crédito do país ao que se refere. Muitas vezes estes spreads por si só também são usados como medida de risco. As Figuras 5 e 6 abaixo ilustram os spreads dos títulos brasileiros e o EMBI BR durante os anos que precederam e sucederam a crise pré-eleição do Lula.

\footnotetext{
$14 \mathrm{O}$ peso de cada instrumento de dívida no $E M B I+$ é dado pelo peso de sua emissão como percentagem do total dos instrumentos no índice e o peso por país é calculado pela agregação dos pesos dos instrumentos para cada país
} 
Figura 5 - Spread dos títulos brasileiros comparado aos títulos de países desenvolvidos

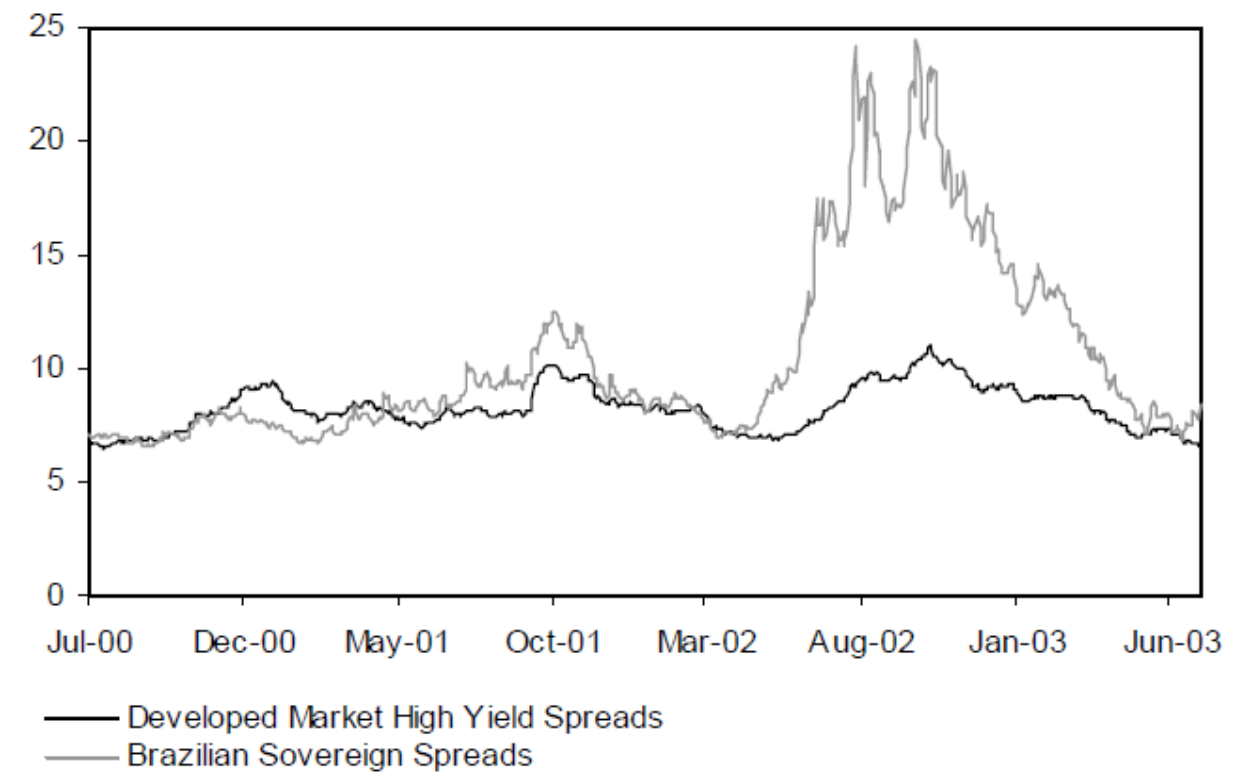

Fonte: GORETTI, 2005.

Figura 6 - Risco Brasil: EMBI (final de período)

\section{RISCO BRASIL - EMBI}

(Final de período)

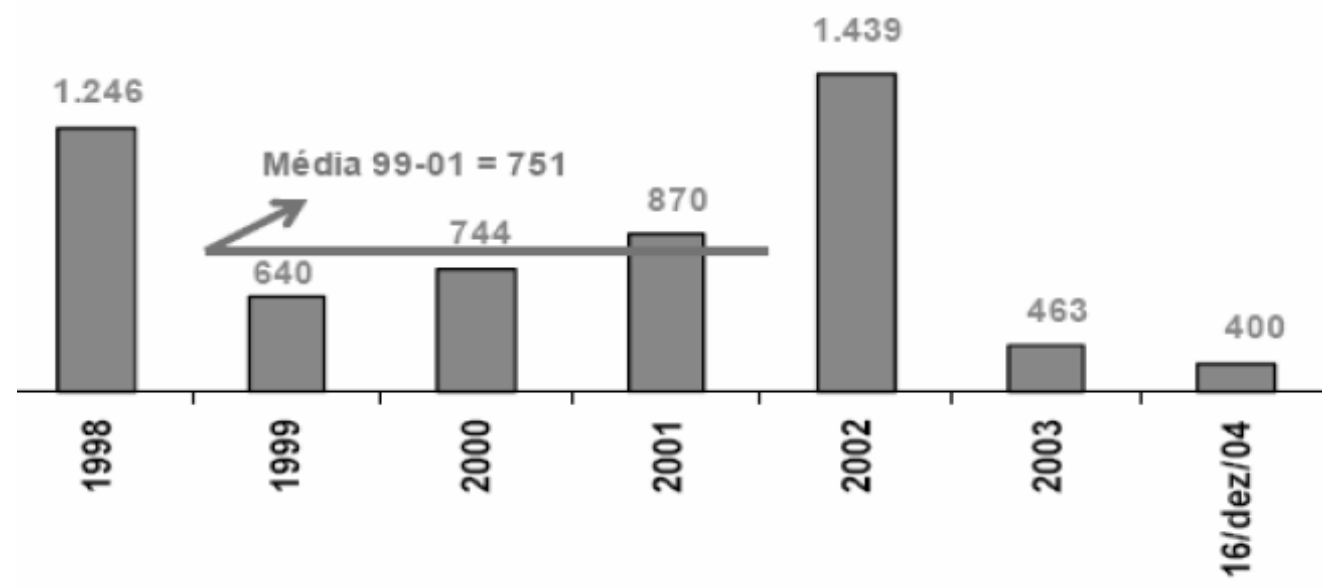

Fonte: TEIXEIRA, 2006. 
Ainda segundo o BACEN ${ }^{15}$ (2016), o prêmio do CDS soberano de um país também pode ser usado como medida do risco-país, já que quanto maior a probabilidade de default maior será o prêmio pago pelo comprador ${ }^{16}$ do $C D S$. Esse é um contrato bilateral que permite ao investidor comprar proteção para crédito específico contra eventos de crédito do emissor de determinado ativo (BANCO CENTRAL DO BRASIL, 2016). A série histórica do CDS Brasil também é foco deste estudo, e certamente o evento nesta seção descrito foi a crise de maior impacto em toda a história deste indicador. O Gráfico 3 abaixo mostra o desenvolvimento do prêmio histórico do CDS Brasil do início de 2002 ao final de 2003.

Gráfico 3 - Série histórica do CDS Brasil durante 2002 e 2003

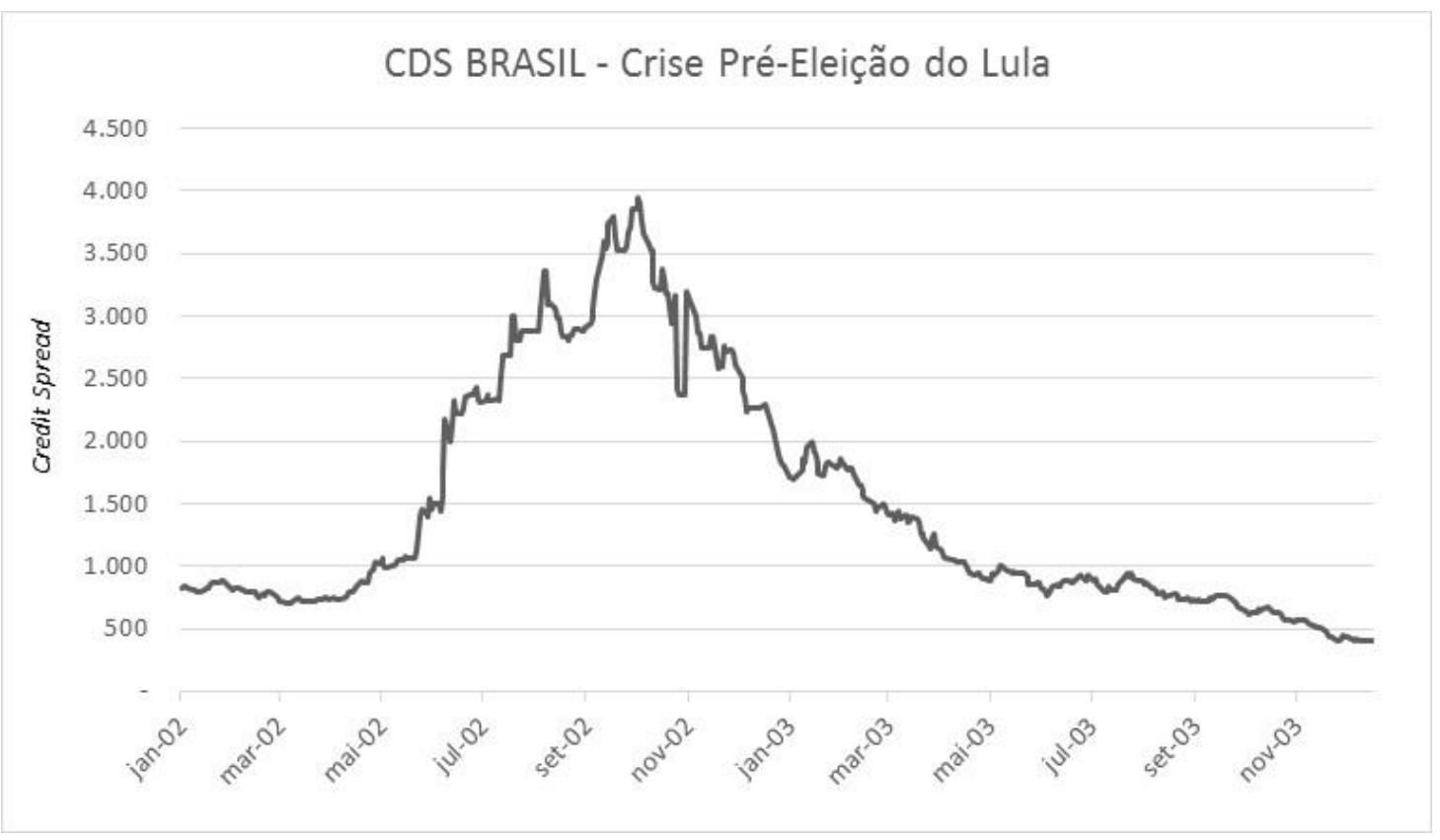

Fonte: elaborado pela autora.

Em meio a tantas incertezas, o dólar atingiu sua máxima histórica da época ${ }^{17}$, saindo de um patamar de 2,26 BRL/USD em abril de 2002 e ultrapassando os 3,95 BRL/USD em 22 de outubro, o que representa uma desvalorização de $74 \%$ em seis meses. O lbovespa também sofreu com a saída massiva do capital estrangeiro do

\footnotetext{
15 Banco Central do Brasil

16 Comprador de proteção

17 A cotação do dólar voltou a bater recorde de alta anos depois, durante o Governo Dilma Rousseff
} 
país, acumulando desvalorização de 34\% no mesmo período. As cotações históricas do câmbio e do Ibovespa durante os anos de 2002 e 2003 estão ilustradas no Gráfico 4 a seguir.

Gráfico 4 - Série histórica do câmbio e Ibovespa durante 2002 e 2003

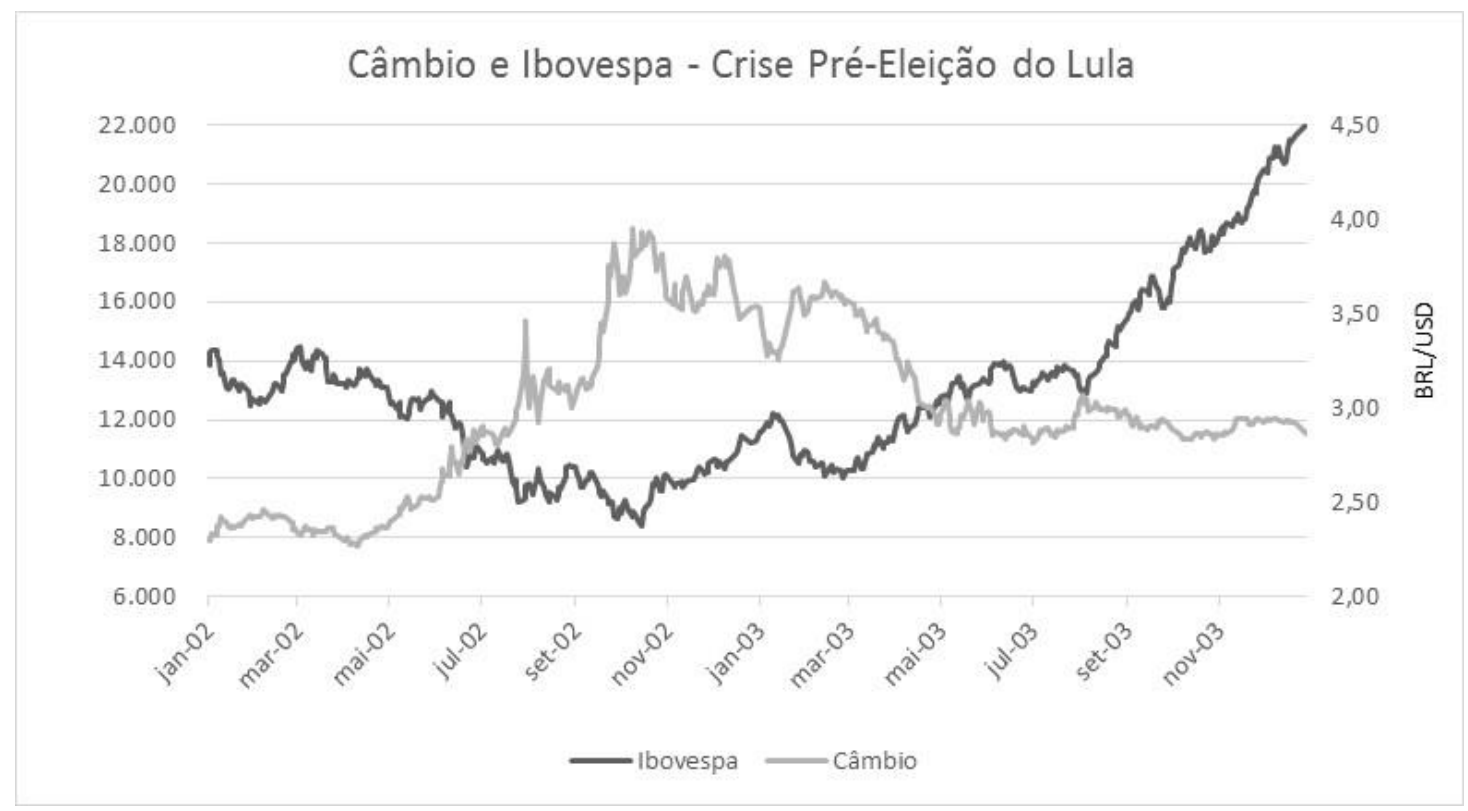

Fonte: elaborado pela autora.

Porém, diante do pânico gerado nos mercados, o candidato, junto ao seu partido (Partido dos Trabalhadores - PT), tratou de tranquilizar a população, publicando a "Carta ao Povo Brasileiro", em junho de 2002, em que se comprometiam a seguir as políticas econômicas já existentes no país. Esta tranquilidade ocorreu apenas após as eleições, quando se viu que mudanças radicais não ocorreriam. Desta forma, o investidor estrangeiro resolveu "dar mais uma chance" ao país, como bem nota a citação do jornal Folha de São Paulo, na época:

"Foi o receio de que uma administração petista conduza o país à moratória que levou os preços dos ativos brasileiros a desabarem. $\mathrm{Na}$ última semana, entretanto, o coração financeiro do mundo decidiu conceder ao Brasil o benefício da dúvida, as cotações experimentaram uma ligeira melhora. Wall Street espera para ver se o Lula que vai tomar posse é a pessoa moderada e com visão que apareceu na campanha, ou se ele voltará à sua essência esquerdista - diz David Roberts, economista internacional do Bank of America Securities" (Folha OnLine, 2002). 


\subsubsection{A Crise Subprime (2007-2009)}

A crise que assolou o mundo em 2007 e 2008 é considerada por muitos economistas como uma das piores crises financeiras da história, sendo superada apenas pela Grande Depressão de 1930. Teve início com o default de hipotecas americanas Subprime (de alto risco) - daí o nome de Crise Subprime - e resultou em queda abrupta da liquidez interbancária, acarretando a falência de várias instituições financeiras, especialmente Bancos de Investimentos, e o encolhimento do mercado imobiliário americano.

De acordo com Bordo e Lane (2010), a crise estava centrada no mercado interbancário de operações compromissadas, que tinham como garantia ativos atrelados a letras hipotecárias de qualidade inferior (Subprime), por meio das quais muitos Bancos de Investimentos e alguns Bancos Múltiplos obtinham seu funding. Com o estouro da "bolha hipotecária" americana, a liquidez deste mercado foi fatalmente reduzida, situação que continuou durante o ano de 2008 e resultou em uma crise bancária sem precedentes, marcada pela quebra do Lehman Brothers, um dos mais tradicionais Bancos de Investimentos do mundo, em setembro de 2008 (que, devido a este fato, ficou conhecido como "Setembro Negro"). Todos estes acontecimentos levaram a uma séria redução na oferta de crédito, e consequente recessão na economia global. A recessão foi atenuada apenas em 2009, por meio de políticas fiscais e monetárias expansionistas postas em prática por grande parte dos Governos europeus e norte americano, além de algumas economias emergentes.

Prates e Cunha (2001) dividem a crise em cinco etapas, seguindo a metodologia proposta pelo BIS ${ }^{18}$. A primeira etapa, de julho de 2007 a março de 2008 , nomeada de "prelúdio", é quando acontece a Crise Subprime propriamente dita, ou seja, nesse momento as turbulências estavam restritas a este mercado, e geograficamente localizadas nos Estados Unidos e algumas economias avançadas que tinham aplicações relacionadas às hipotecas norte americanas. A maioria das economias emergentes, naquela época, não estavam integradas a este mercado, e, portanto, permaneceram incólumes neste primeiro momento. Ao contrário, algumas

${ }^{18}$ Bank of International Settlements 
Bolsas de Valores, como a Bovespa, apresentaram recordes de alta em suas cotações nesta época. Daí foi formada a teoria do "descolamento" (decoupling), segundo a qual as economias emergentes, que vinham apresentando melhor desempenho neste primeiro momento da crise, não seriam contaminas pela turbulência financeira.

Porém, entre março e setembro de 2008, a crise começou a se espalhar para outros segmentos do mercado financeiro, devido principalmente à diminuição da liquidez do mercado interbancário. Esta segunda fase ficou marcada pelos resgates e aquisições de importantes instituições financeiras, e culminou na falência do Lehman Brothers. Neste momento muitas economias emergentes foram atingidas por meio da retração das linhas de crédito bancárias, especialmente aquelas com elevados déficits em conta corrente (como Turquia e África do Sul) ou alto endividamento de curto prazo (caso da Coréia do Sul) (PRATES e CUNHA, 2011).

A terceira fase, de setembro a outubro de 2008 , foi quando a crise se tornou um evento sistêmico e, segundo os autores, uma "crise de confiança global". Esta foi a fase mais curta, porém mais aguda da crise, e resultou na paralisia do sistema financeiro mundial, contagiando também os mercados emergentes.

"O efeito-contágio da crise sobre as regiões emergentes ocorreu
mediante vários canais de transmissão, envolvendo, seja a conta
corrente (queda dos preços das commodities e da demanda mundial e
aumento das remessas de lucros pelas empresas e bancos), seja a
conta financeira (menor ingresso de investimento direto, saída dos
investimentos de portfólio, interrupção das linhas de crédito comercial
e forte contração dos empréstimos bancários)" (PRATES e CUNHA,
2011).

Desta forma, a teoria do decoupling ia por água abaixo. Conforme constataram Frank e Hesse (2009), ao contrário do que era previsto por esta teoria, as correlações entre os U.S. Libor-OIS ${ }^{19}$ spreads, usados como proxy para a liquidez interbancária, e os spreads de títulos soberanos do EMBI+ para economias emergentes da Europa, Ásia e América Latina aumentaram significativamente durante a crise. Em termos dos países individualmente, os autores encontraram íntima ligação entre os U.S. Libor-

\footnotetext{
${ }^{19}$ United States (U.S.) London Interbank Offered Rate (LIBOR) Overnight Indexed Swap (OIS)
} 
OIS spreads e os CDS spreads soberanos do Brasil, Rússia, Turquia, México e África do Sul.

A Figura 7 abaixo mostra o desenvolvimento do spread e retorno do EMBI+ durante a crise Subprime e os anos anteriores e posteriores a ela. Os aumentos dos spreads durante o período de crise são facilmente notados, assim como a diminuição dos retornos dos títulos soberanos ${ }^{20}$. Interessante notar também os picos dos spreads nos anos anteriores a 2008, provavelmente correspondentes à aversão ao risco causada pelo Ataque Terrorista às Torres Gêmeas (2001) e a Crise Pré-Eleição do Lula (2002), eventos que também são objeto deste estudo, conforme visto nas seções anteriores.

Figura 7 - Spread e retorno do EMBI+ (2000 a 2006)

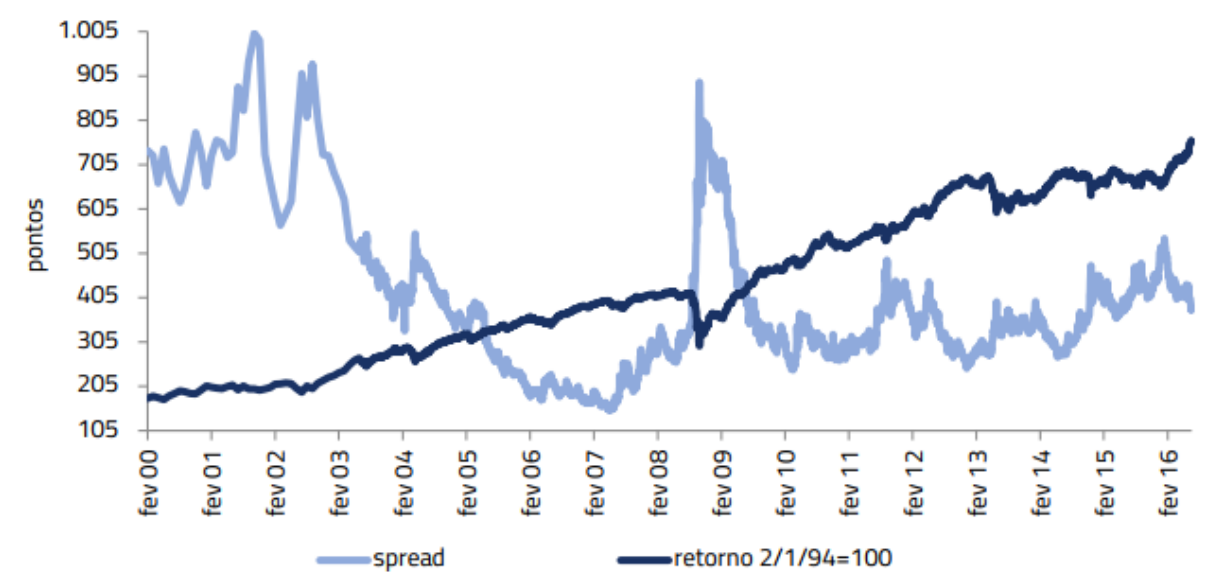

Fonte: BANCO CENTRAL DO BRASIL (2002).

Por fim, a quarta fase da crise, de outubro de 2008 a março de 2009, englobou as políticas monetárias e reações dos diversos Bancos Centrais do mundo inteiro, injetando liquidez nas economias, cortando taxas de juros e comprando títulos e, principalmente, garantindo as operações interbancárias. A quinta fase aconteceu então quando surgiram os primeiros sinais de estabilização dos mercados financeiros, em março de 2009.

20 Os spreads e preços dos títulos são inversamente proporcionais após sua emissão 
Durante estes anos, o Brasil colhia os frutos da consolidação de sua estabilidade econômica, processo que teve início na década 1990. Além disso, se beneficiava de alta expressiva nos preços das commodities agrícolas e minerais, devido ao grande aumento de demanda causado pelo crescimento desenfreado da China e Índia. Todo este contexto permitiu que o país implantasse um programa de distribuição de renda, que contribuiu em muito para o aumento do poder de compra de milhões de brasileiros, aquecendo também o mercado interno do país.

Porém, segundo notou RIBEIRO (2010):

\begin{abstract}
"A bonança econômica, no entanto, não pareceu imunizar nosso país dos ventos da crise internacional que estaria por vir. Com sua eclosão, o Brasil foi forçado a adotar um leque de políticas macroeconômicas com objetivo de minorar os efeitos negativos dela decorrentes. [...] a crise foi mais intensa nas economias do centro do capitalismo global contemporâneo, pois as mesmas são mais dependentes do sistema global de comércio e financiamento. Por serem mais globalizadas e possuírem sistemas financeiros sofisticados, robustos, complexos e profundamente interligados, estas nações sofreram mais do que algumas nações menos desenvolvidas, como o Brasil, por exemplo, as quais prescindem dos mecanismos financeiros com mais intensidade do que as nações centrais".
\end{abstract}

Ainda assim, os indicadores econômicos do Brasil na época revelam que a economia do país sofreu, sim, com a crise. O Ibovespa, que havia alcançado o recorde histórico de 73.516,81 pontos em maio de 2008, rapidamente despencou para 29.435,11 pontos no mês de outubro seguinte, acumulando desvalorização de praticamente $60 \%$ num intervalo de pouco mais de cinco meses. O câmbio também sofreu desvalorização da mesma ordem, indo do mínimo de 1,562 BRL/USD em abril de 2008 até o máximo local de 2,513 BRL/USD em dezembro do mesmo ano, o que significa $61 \%$ de desvalorização neste período. Por fim, o efeito da crise foi ainda mais radical sobre o CDS soberano do Brasil. Houve um aumento de mais $854 \%$ do prêmio do CDS Brasil de 5 anos comparando-se o nível de risco de outubro de 2008 com maio do mesmo ano. Os Gráficos 5 e 6 ilustram estes dados. 
Gráfico 5 - Série histórica do câmbio e lbovespa, no período de 2007 a 2010

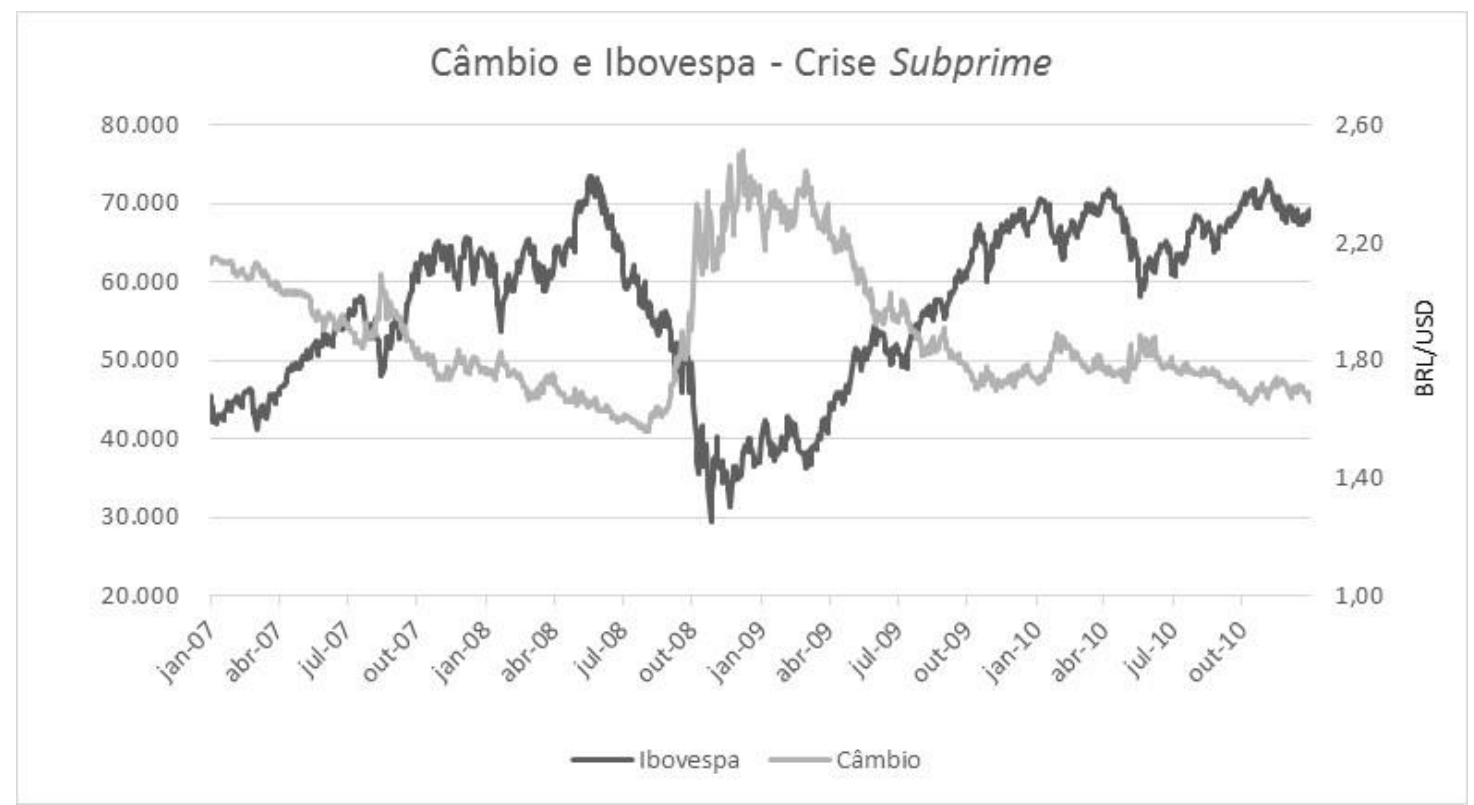

Fonte: elaborado pela autora.

Gráfico 6 - Série histórica do CDS Brasil, no período de 2007 a 2010

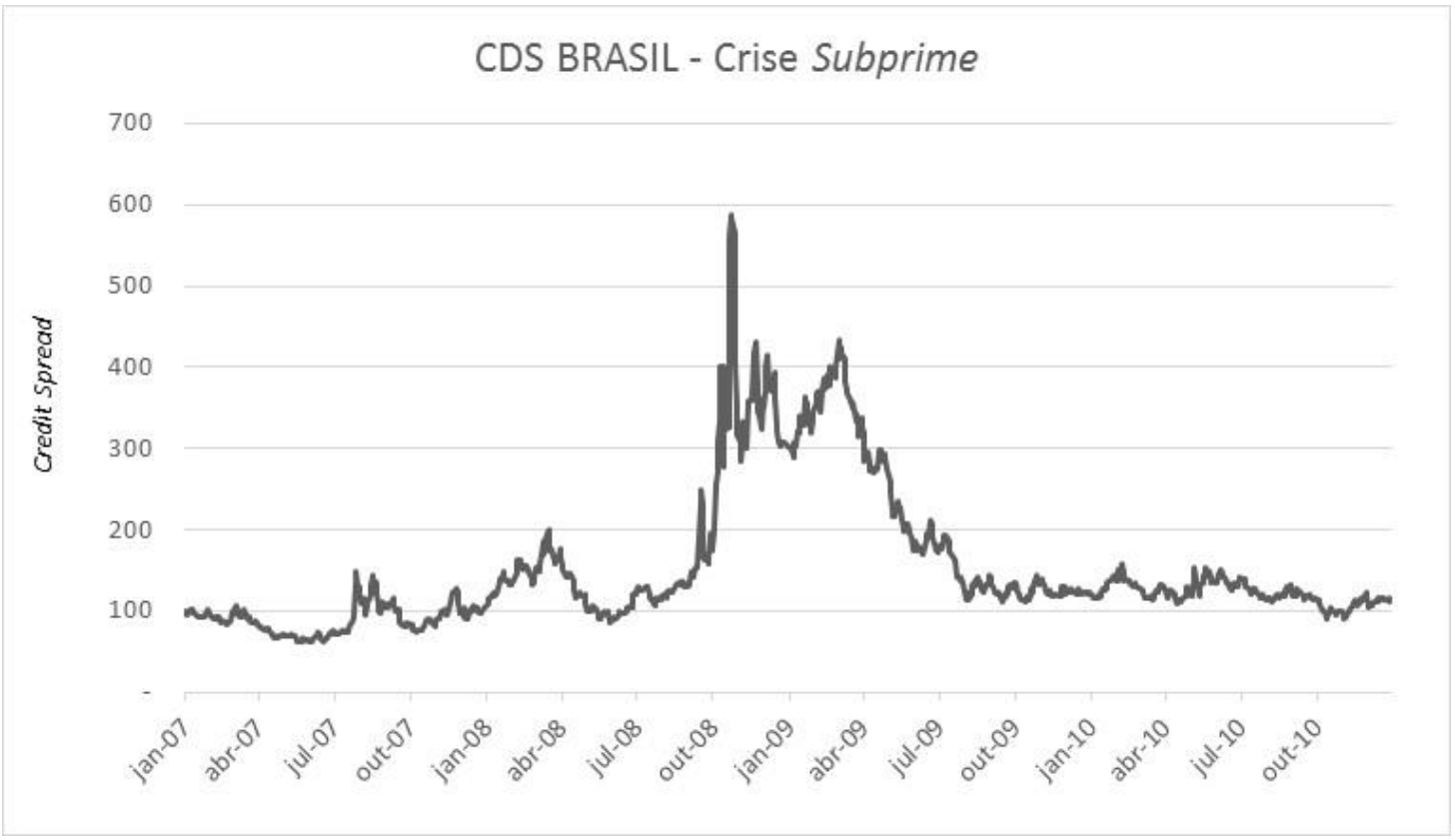

Fonte: elaborado pela autora. 


\subsubsection{A Crise do Governo Dilma Rousseff $(2015,2016)$}

Até 2010, O Brasil nutria auto percepção e exibia no exterior uma imagem de país emergente promissor e dinâmico. Percepção interna e imagem externa estavam baseados em sólidos fundamentos como a estabilidade econômica e política, a recente inclusão de parte da camada mais pobre à sociedade de bem-estar mínimo e uma política exterior assertiva que posicionava a nação no mundo, além de dinâmica internacionalização de empresas brasileiras (CERVO e LESSA, 2014). Porém, este quadro se reverteu quando Dilma Rousseff tomou posse como presidente do país, em 2011.

Segundo os autores, a presidente não formulou uma política de comércio exterior e não programou junto ao empresariado uma estratégia de inovação exigida pela competitividade sistêmica de economias internacionalizadas. O Governo de Dilma não apenas falhou em enfrentar os entraves ao crescimento preexistentes, como a insuficiente infraestrutura e a elevada carga tributária, como ainda agregou novos entraves: inchou a máquina do Estado, sustou o diálogo com o empresariado e não supriu, enfim, a baixa propensão das empresas em inovar com política de Estado de inovação tecnológica. Assim, de acordo com os autores:

"Os resultados da queda de eficiência do paradigma logístico de aliança Estado-sociedade são concretos e incidem sobre os fundamentos internos da emergência no cenário internacional: queda do percentual da indústria no PIB, reprimarização econômica, queda das exportações, especialmente de manufaturados, queda do crescimento econômico e, mais grave, quebra da confiança no país do empresariado nacional e estrangeiro" (CERVO e LESSA, 2014).

Toda esta situação, somada ao cenário externo de desaceleração do crescimento econômico liderado pela China, e consequente baixa dos preços das commodities, levaram o Brasil à sua pior crise desde a recessão de 1931 (2014-217 Brazilian Economic Crisis, WIKIPEDIA). E, como se tudo isso não fosse suficiente, o país ainda afundou numa crise política sem precedentes, que destituiu a presidente de seu cargo, e trouxe à tona diversos escândalos de corrupção envolvendo relações criminosas entre grandes empresas nacionais e políticos de diversos partidos, comprometendo ainda mais a confiança do investidor estrangeiro. 
Durante o primeiro mandato de Dilma Rousseff, de 2011 a 2014, o Brasil cresceu em média 2,2\% ao ano, taxa inferior ao crescimento da maioria dos vizinhos latino-americanos (THE ECONOMIST, abril 2016). O segundo mandato foi ainda mais desastroso, com dois anos de retração consecutivos: -3,8\% em 2015 e -3,6\% em 2016. Situação igual a esta, dois anos consecutivos de retração, foi vista apenas na ocasião da Grande Depressão em 1930. A Figura 8 a seguir mostra a variação do Produto Interno Bruto (PIB) do país nos últimos 10 anos.

No que pese que parte da desaceleração econômica da época foi comum aos mercados emergentes, causada principalmente pela queda dos preços das commodities, O Governo Dilma tornou a situação ruim ainda pior. Durante seu primeiro mandato, Dilma e seu partido (Partido dos Trabalhadores - PT) fizeram gastos extravagantes e pouco inteligentes, como aumento de pensões e improdutivos cortes de impostos para certas indústrias favorecidas. Como resultado, o déficit fiscal do país, que representava $2 \%$ do PIB em 2010, alcançou inacreditáveis 10\% em 2015 (THE ECONOMIST, janeiro 2016).

Figura 8 - Variação anual do Produto Interno Bruto do Brasil

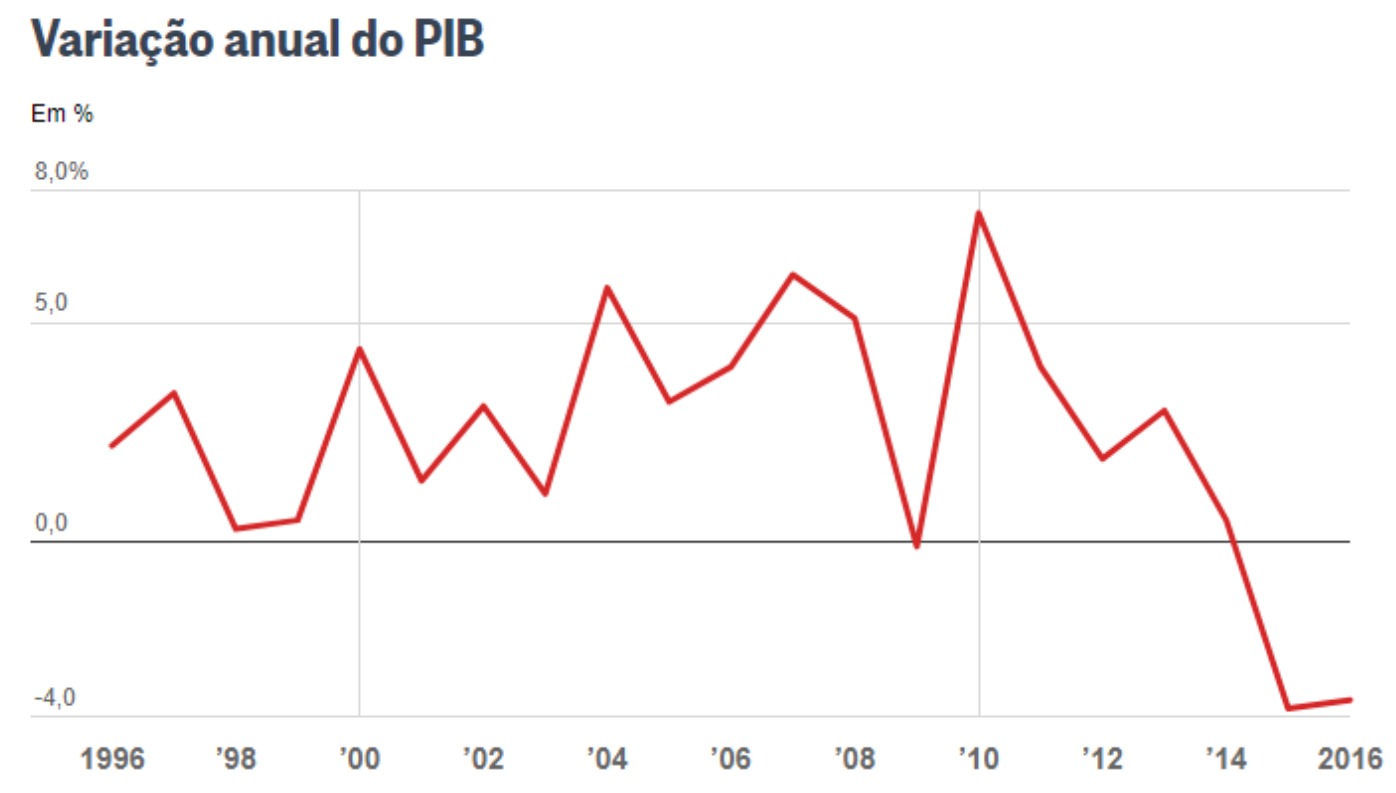

Fonte: O GLOBO (2017). 
Quando a política fiscal é dominante, qualquer aumento nas taxas de juros acarreta aumento também dos juros da dívida do Governo, comprometendo sua saúde fiscal, desvalorizando a moeda local, e consequentemente gerando inflação (DELOITTE, 2016). Adicionalmente, o Banco Central cortou as taxas de juros prematuramente em 2011 e 2012. O resultado foi uma taxa inflação no período muito longe da meta de 4,5\% ao ano e bem acima da banda superior de 6,5\% (THE ECONOMIST, abril 2016).

Conforme mencionado no início desta seção, a alta burocracia, falta de infraestrutura e o câmbio apreciado (no passado) tornaram a indústria brasileira pouco competitiva. A alta das commodities também contribuiu para esta situação, de forma que os investimentos do país foram voltados mais para o agronegócio e menos para a indústria. Desta forma, o consumo interno têm sido a maior fonte de demanda do país. Porém, com a crise econômica, os salários reais (descontada a inflação) começaram a decrescer, especialmente a partir de março de 2015. O desemprego também aumentou significativamente, saindo de um patamar de $5 \%$ em 2014, alcançando $9,5 \%$ no início de 2016 e com previsão de exceder os $10 \%$ no mesmo ano. Diante de toda esta situação, a confiança do consumidor caiu ao menor nível desde que passou a ser monitorada pela Fundação Getúlio Vargas, em 2005 (THE ECONOMIST, abril 2016).

O Governo brasileiro se viu então numa situação sem saída. Retração econômica somada à alta inflação, o que impossibilita o corte de juros como incentivo ao crescimento; Estados falidos e sem recursos para investimentos, consumo interno baixo devido à falta de confiança e de emprego. O único setor que conseguiu apresentar leve crescimento na época foram as exportações, que se beneficiaram do câmbio desvalorizado (DELOITTE, 2016). E, em meio a toda esta crise, como era de se esperar, o Brasil ainda perdeu o grau de investimento concedido pelas maiores agências mundiais de ratings, sendo rebaixado a junk investment ${ }^{21}$.

Não bastasse o desastre econômico, uma crise política histórica assolou o país na mesma época. A Operação Lava Jato, conforme denominada pela Polícia Federal,

\footnotetext{
${ }^{21}$ Investimentos ou títulos classificados com alto risco de default
} 
foi iniciada em março de 2014, com o intuito de investigar o sistema de corrupção entre empresas de construção civil, políticos de alto escalão e a Petrobrás, maior indústria petroleira do país. Investigadores acusaram os diretores da empresa petroleira de receber altas propinas em troca dos contratos de obras para as empresas de construção (BBC News, 2017).

Como a Petrobrás é uma empresa controlada pelo Governo, logo o Partido dos Trabalhadores se viu envolvido em denúncias contra dezenas de seus integrantes, que supostamente usaram os recursos recebidos por meio do esquema de propinas para financiar suas campanhas. Entre eles estavam o ex-presidente Lula, a expresidente Dilma (que foi desposta do cargo por motivo diferente) e o atual presidente, Michel Temer (que assumiu a presidência após o impeachment de Dilma).

Em meio a todos estes escândalos de corrupção, Dilma Rousseff foi também acusada de manipular o orçamento do país, de forma a esconder "rombos" nas contas públicas, tendo em vista principalmente sua candidatura à reeleição em 2014. A presidente for reeleita em 2014, porém seu segundo mandato não se estendeu muito, já que ela foi afastada do cargo em maio de 2016. Após as investigações e votações na Câmara dos Deputados e no Senado Federal, Dilma sofreu impeachment em agosto de 2016, sob alegação de, entre outros, crime contra a Lei de Responsabilidade Fiscal.

Apesar de o Partido dos Trabalhadores como um todo alegar inocência em todas estas acusações e argumentar que seus integrantes têm sido vítimas de perseguição política, a confiança do investidor, já abalada pela crise econômica, foi seriamente comprometida. A saída massiva de capital do país provocou a maior alta da cotação dólar-real de toda a história do câmbio flutuante. Em 28 de setembro de 2015 o dólar atingiu a cifra de 4,178 reais, após o presidente do Banco Central Europeu, Mario Draghi, expressar preocupação com o crescimento global e a situação do Brasil em particular. Comparando este máximo ao mínimo local de 2,19 reais ocorrido em abril de 2014, a depreciação do câmbio foi de $91 \%$.

O impacto no lbovespa, por sua vez, não foi tão radical. A Bolsa sofreu queda de quase $40 \%$ entre o ponto de máximo de $61.895,98$ pontos, em setembro de 2014 , e o mínimo local de 37.497 pontos, ocorrido em janeiro de 2016. 
Por fim, o CDS Brasil, como havia de ser esperar, também apresentou alta abrupta, alcançando o topo junto ao dólar, em setembro de 2015. Foram mais de $330 \%$ de aumento no risco país, no período de um ano (setembro de 2014 a setembro de 2015). Os Gráficos 7 e 8 a seguir mostram estes dados.

Gráfico 7 - Série histórica do câmbio e do lbovespa, no período de janeiro de 2014 a setembro de 2016

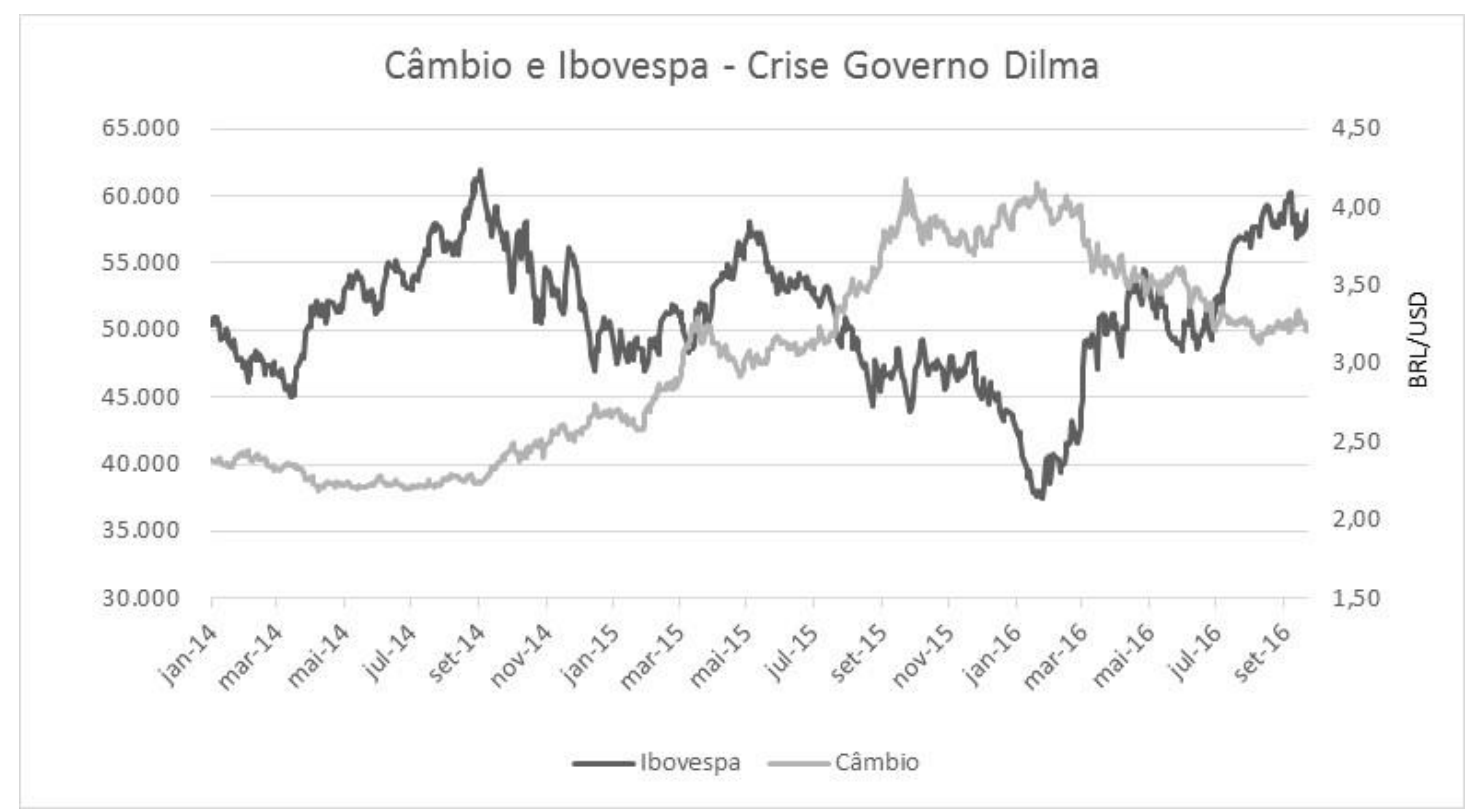

Fonte: elaborado pela autora. 
Gráfico 8 - Série histórica do CDS Brasil, no período de janeiro de 2014 a setembro de 2016

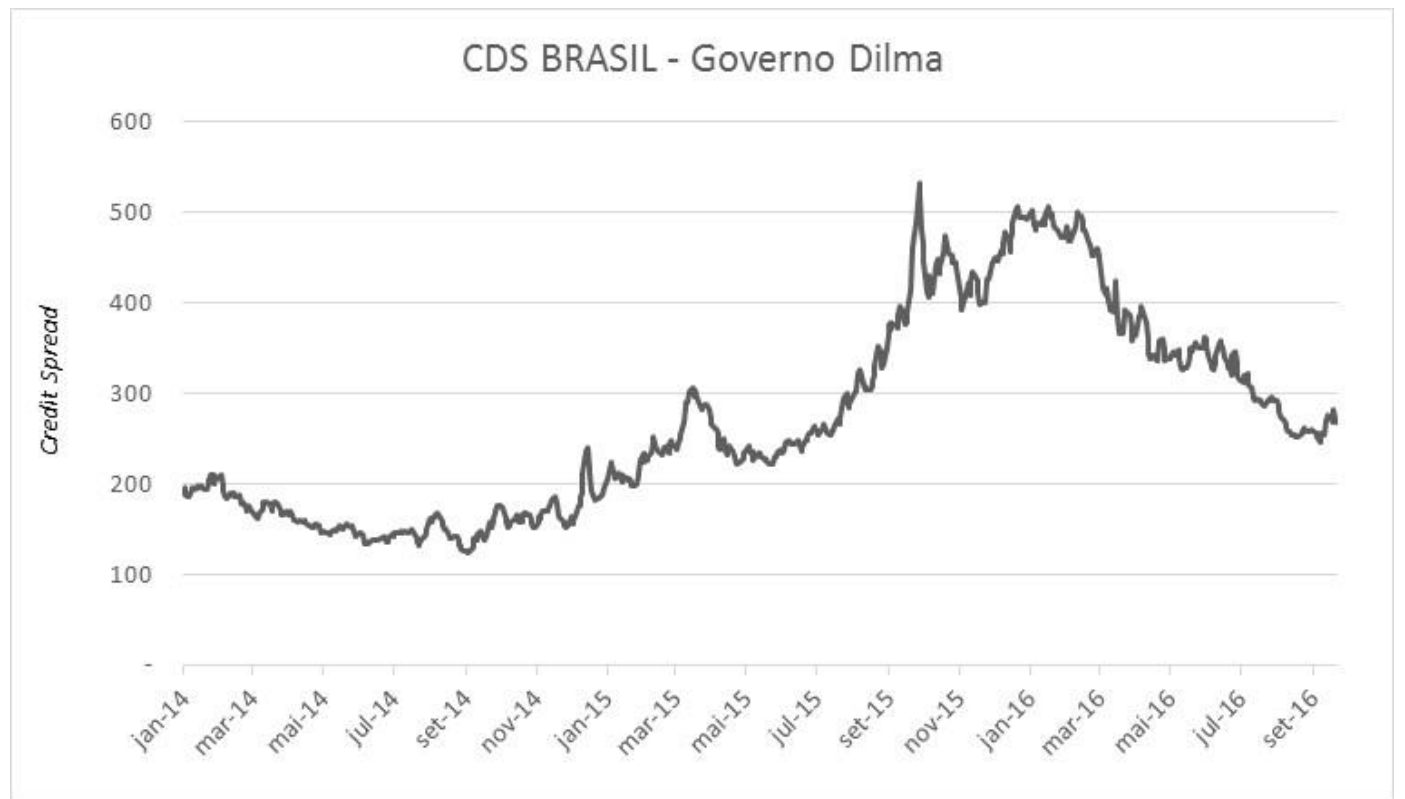

Fonte: elaborado pela autora. 


\section{Estudo Empírico}

Este capítulo cuida da parte empírica deste estudo, descreve os dados e a metodologia aqui aplicados. Os eventos de crise são facilmente identificados por meio da análise visual dos dados, e confirmados com a aplicação das medidas de Complexidade. Analisar o passado é de certa forma simples, porém o objetivo maior deste estudo é "voltar no tempo" e testar se seria possível identificar os eventos de crise logo em seu início, de posse da pouca informação disponível no momento. A metodologia para tal é então descrita na seção seguinte. Ao final do capítulo são descritos os resultados encontrados.

\subsection{Dados}

Este trabalho busca analisar as mudanças na complexidade da taxa de câmbio dólar-real, do lbovespa e do CDS soberano do Brasil frente a crises financeiras. Para tal faz-se uso das séries financeiras da taxa de câmbio reais/dólares, a cotação diária de fechamento do lbovespa e o spread de crédito do CDS (Credit Default Swap) Brasil, num horizonte de tempo que se inicia em janeiro de 1999 e tem fim em setembro de 2016.

A taxa de câmbio aqui utilizada é o BRL (Brazilian Real) spot. O que define uma taxa de câmbio spot é a entrega imediata (normalmente com liquidação em 2 dias úteis), diferentemente de um forward ou contrato futuro, que tem vencimento em um tempo futuro. Esta é a taxa da moeda nacional (BRL) frente ao dólar americano (USD), e é expressa em termos da quantidade de reais para cada dólar (BRL/USD). Todas as séries deste estudo foram capturadas via terminal da Bloomberg'22, e expressam cotações de fechamento do dia (no caso da taxa de câmbio o ponto de corte acontece às $19 \mathrm{hs}$, horário oficial de Brasília).

\footnotetext{
22 A Bloomberg L.P. é uma empresa de tecnologia e dados para o mercado financeiro e agência de notícias em todo o mundo, com sede em Nova York. Terminal Bloomberg é um computador customizado para a base dados Bloomberg, da qual se pode extrair todas as séries financeiras compiladas pela empresa.
} 
A amostra da série de câmbio é constituída de 4.362 observações, com valor mínimo de BRL/USD 1,2071, em janeiro de 1999, quando o câmbio começou a flutuar; e máximo de BRL/USD 4,1780, em setembro de 2015, em meio à recente crise econômica e política da qual o País ainda se recupera. A média da amostra é de BRL/USD 2,3185 com desvio-padrão de BRL/USD 0,5949.

Analisando visualmente o gráfico da série destacam-se cinco pontos de máximo locais, estando o primeiro logo no início da série, em janeiro de 1999; seguido por outro por volta de setembro de 2001; outubro de 2002; outubro de 2008 e ao final da amostra, em setembro de 2015 (máximo global da série) e janeiro de 2016. Estes pontos coincidem com os eventos de crise que são aqui estudados: Crise Cambial de 1999, Crise do Ataque às Torres Gêmeas, Crise Pré-Eleição do Lula, Crise Subprime e Crise do Governo Dilma, respectivamente.

O lbovespa - Índice Bovespa é o principal índice de ações da Bolsa Brasileira (BM\&F Bovespa) e é o resultado de uma carteira teórica de ativos, elaborada de acordo com os critérios estabelecidos em sua metodologia ${ }^{23}$. Seu objetivo é ser o indicador de desempenho médio das cotações dos ativos de maior negociabilidade e representatividade do mercado de ações brasileiro. O Ibovespa é um índice de retorno total e é expresso em número de pontos, partindo de 100 pontos, em janeiro de 1968, quando começou a ser compilado. Os dados do lbovespa são divulgados diariamente no site da Bovespa na internet ${ }^{2}$.

Esta amostra também é constituída de 4.362 observações, com mínimo de 5.057 pontos no início da série (janeiro de 1999) e máximo de 73.516 pontos em maio de 2008, poucos meses antes do início da Crise Subprime. Aqui pode-se novamente observar os mesmos eventos de crises citados anteriormente, porém, para o índice da Bolsa de Valores, estes são pontos de mínimos ${ }^{24}$, já que os eventos de crise normalmente desencadeiam o movimento de vendas das ações, causando diminuição de seus preços, e consequente decréscimo do Índice.

O Gráfico 9 a seguir plota as duas séries descritas acima. Por meio de sua observação não é difícil notar que existe uma correlação negativa entre ambas (da

\footnotetext{
${ }^{23}$ Disponível em www.bmfbovespa.com.br

${ }^{24}$ Exceto na Crise Cambial de 1999, quando o Ibovespa subiu, alcançando ponto de máximo local
} 
ordem de $-33 \%$ na amostra utilizada). Este é um fato amplamente conhecido no Mercado Financeiro brasileiro e dá suporte à teoria conhecida como Portfolio Approach, de acordo com a qual o preço das ações influencia (negativamente) as taxas de câmbio por meio de fluxos de capitais estrangeiros para dentro e para fora do País. Desta forma, se há uma tendência positiva no preço das ações, espera-se que a entrada de capitais estrangeiros no país aumente, valorizando o câmbio (diminuindo a taxa BRL/USD). Ao contrário, se a tendência dos preços é de baixa, há uma redução na renda do investidor doméstico, diminuindo a demanda por moeda e as taxas de juros, tornando o país menos atrativo ao investidor estrangeiro (TABAK, 2006). Em épocas de crise, porém, o fluxo de capitais para fora do país está mais ligado ao maior grau de aversão ao risco do investidor estrangeiro, que prefere mover seu capital para investimentos mais seguros, nos países desenvolvidos, causando larga depreciação da moeda nacional (aumento da taxa BRL/USD).

Gráfico 9 - Série histórica do câmbio e lbovespa e os eventos de crise

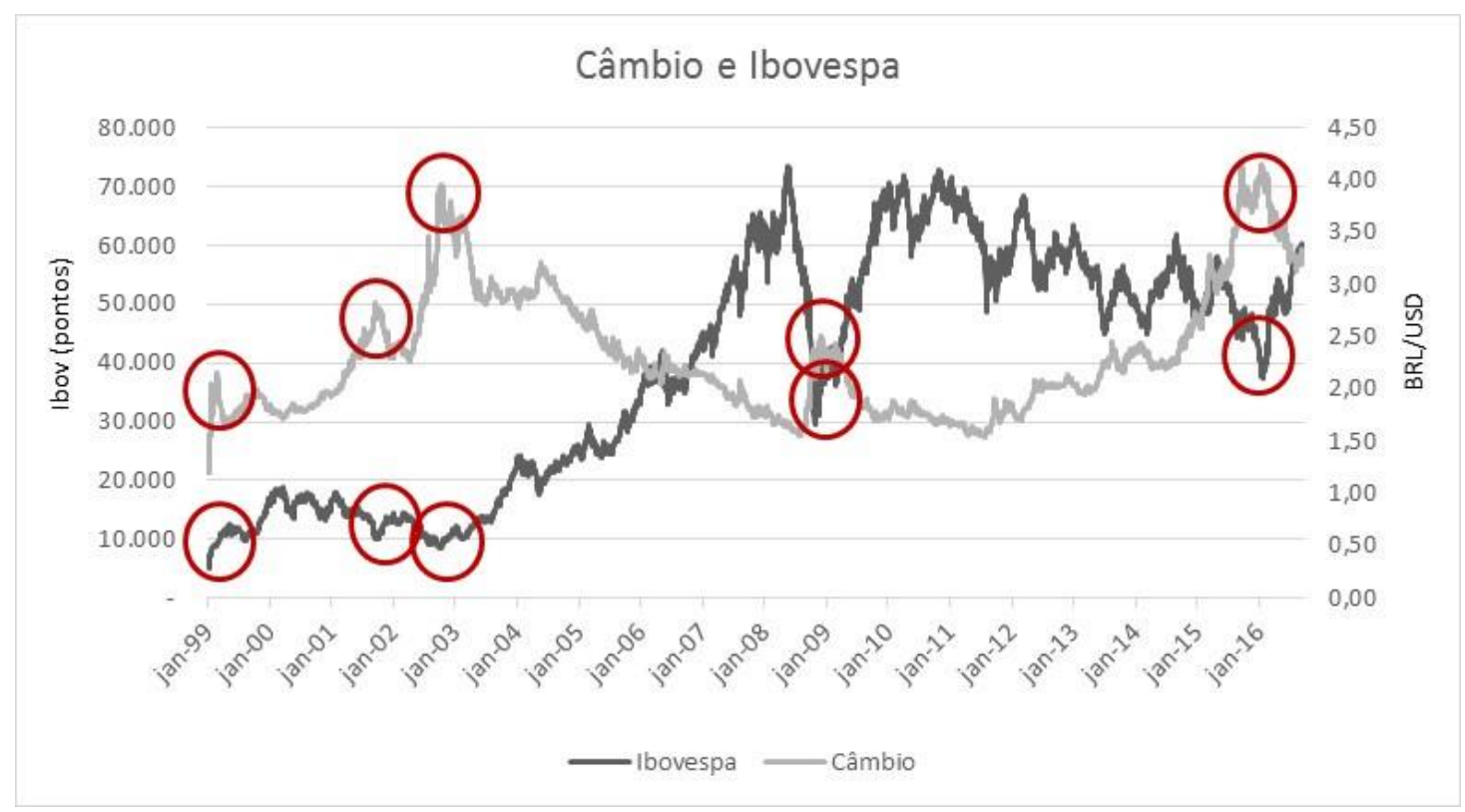

Fonte: elaborado pela autora.

Por fim, a terceira série financeira aqui analisada é constituída pelo spread do Credit Default Swap (CDS) soberano do Brasil. Um CDS é um derivativo de crédito expresso por meio de um contrato bilateral no qual uma contraparte, chamada de 
comprador da proteção, paga uma taxa periódica ou prêmio (spread) sobre um valor nocional (ou principal) em troca de um pagamento contingencial, efetuado pela outra contraparte, o vendedor da proteção, no caso de ocorrência de um evento de crédito de uma entidade de referência (JP MORGAN, 1999). No caso do CDS soberano do Brasil, o comprador adquire proteção contra um possível default do Governo Brasileiro. Desta forma, o $C D S^{25}$ Brasil mede o chamado risco-país.

A Figura 9 abaixo ilustra o funcionamento do $C D S$ no caso dos títulos da dívida soberana do Brasil. O Governo Brasileiro emite títulos da dívida, remunerados por meio da taxa de juros mais um spread, que são comprados pelos investidores (comprador da proteção). Para se proteger de um possível default, o investidor compra proteção $(C D S$ ), pagando um prêmio (ou CDS spread) para o vendedor da proteção. Se não ocorrer o default, ao final do contrato o Governo Brasileiro devolve o valor do principal ao investidor, e o CDS expira. Caso ocorra default, O Governo Brasileiro paga ao investidor a recovery rate (taxa de recuperação), e o vendedor da proteção paga a diferença entre o principal e a recovery rate.

Figura 9 - Como funciona o CDS soberano do Brasil

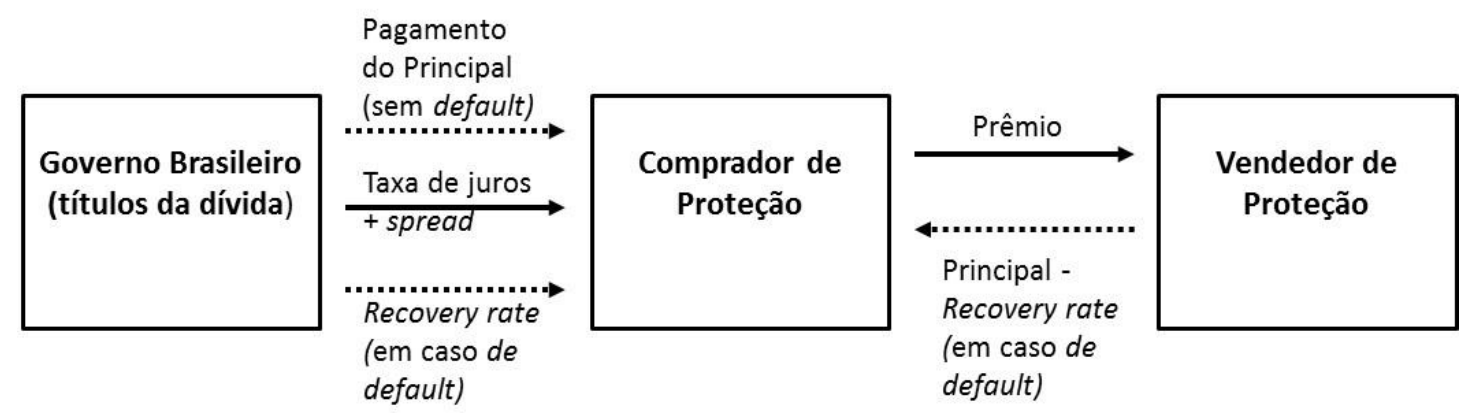

Fonte: adaptado de Deutsche Bank Research

Esta é uma série mais curta que as demais, já que, como nota ARCOVERDE (2002), este é um mercado tardiamente desenvolvido no Brasil, principalmente devido ao passado de altas taxas de inflação. Assim, a série estudada tem início em janeiro

\footnotetext{
${ }^{25}$ Os CDS são emitidos com diferentes maturidades, de acordo com os prazos dos ativos aos quais esses oferecem proteção. Os dados aqui utilizados são do CDS Brasil de 5 anos, o mais líquido da série
} 
de $2002^{26}$ e termina em setembro de 2016, e está ilustrada no gráfico a seguir. É constituída de 3,614 observações diárias, variando entre o mínimo de 61,50 basis points ${ }^{27}$, em maio de 2007, até o máximo de 3.951,50, em outubro de 2002. A média é de 387,11 e o desvio-padrão 568,46. Nesta série pode-se também notar a presença dos eventos de crise já citados, neste caso a Eleição do Lula (Outubro de 2002), a Crise Subprime (outubro de 2008) e Crise do Governo Dilma (setembro de 2015 e janeiro de 2016). Há ainda um ponto de máximo local por volta de meados do ano de 2004, provavelmente causado pelo anúncio da possível alta das taxas de juros nos Estados Unidos (DEUTSCHE BANK RESEARCH), porém este evento não faz parte do escopo deste trabalho.

Gráfico 10 - Série histórica do CDS Brasil e os eventos de crise

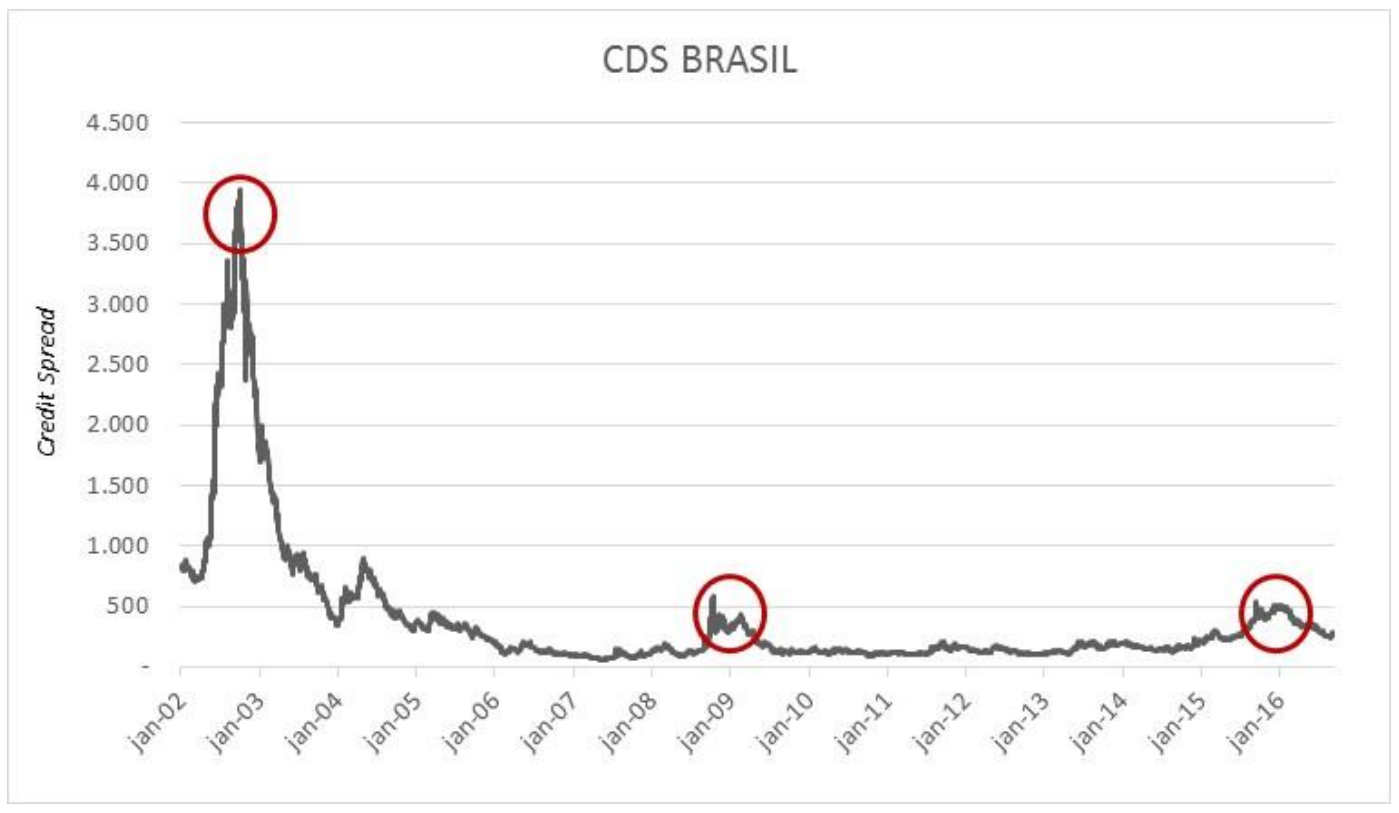

Fonte: elaborado pela autora.

De acordo com o Banco Central do Brasil (2016), o risco-país, aqui representado pelo CDS Brasil, é altamente (positivamente) correlacionado à taxa de câmbio dólar-real. Isto acontece porque, em economias abertas com câmbio

26 Existem dados disponíveis para os anos anteriores, porém as observações são escassas, comprometendo a qualidade da série

271 basis point equivale a $0,1 \%$ ou 0,001 
flutuante, geralmente as variações da percepção de risco soberano são acompanhadas por variações nas entradas líquidas de capitais, com impacto na taxa de câmbio. O Gráfico 11 a seguir exibe as duas séries juntas, onde a correlação positiva é facilmente observada. Para estas séries, neste intervalo de tempo (janeiro de 2002 a setembro de 2016), a correlação calculada foi de 56\%.

Gráfico 11 - CDS Brasil e o câmbio dólar-real

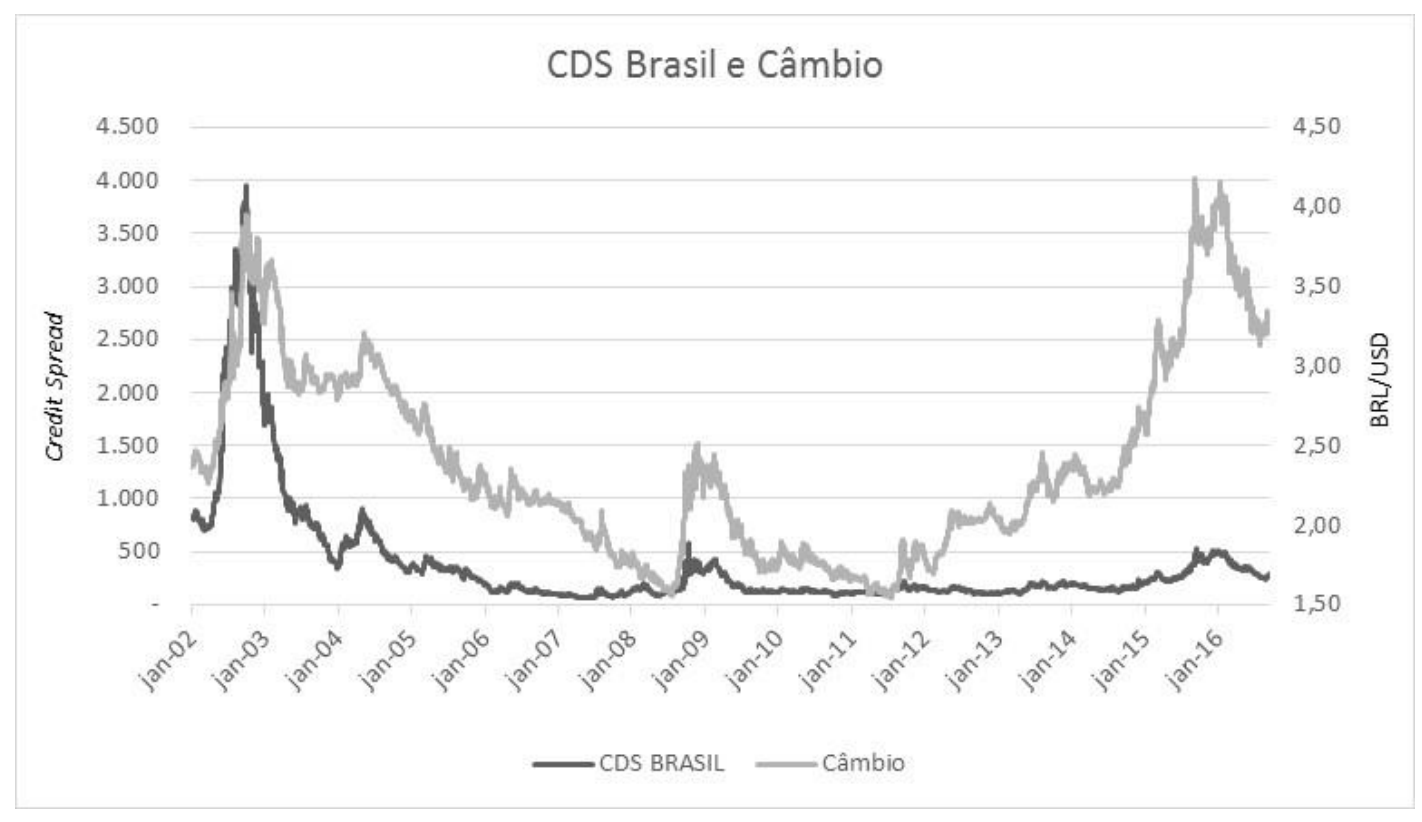

Fonte: elaborado pela autora.

\subsection{Metodologia}

O cálculo da Complexidade começa com a construção de um conjunto finito de estados mensuráveis, de acordo com Piqueira, Serboncini e Monteiro (2006). Analisando a amostra coletada, cada estado pode ser associado à sua frequência de ocorrência relativa no sistema, interpretada como um vetor de probabilidades. $\mathrm{Na}$ prática, isso significa a divisão dos dados em intervalos de tamanhos iguais. Não há um cálculo do número ótimo de intervalos, de forma que esta definição é feita por meio de experimentação. 
Feita a divisão da amostra, pode-se observar quantas realizações ocorrem em cada intervalo e, a partir deste número, obtém-se a probabilidade $\left(p_{i}\right)$ de ocorrência de cada um deles:

$$
p_{i}=\frac{\text { número de ocorrências em } i}{\text { número total de observações }}
$$

Dadas as probabilidades de cada intervalo, calcula-se então a entropia $\left(H_{i}\right)$, ou quantidade de informação, de cada intervalo:

$$
H_{i}=p_{i} * \ln \left(p_{i}\right)^{-1}
$$

E a entropia máxima do sistema:

$$
H^{\max }=\ln N
$$

onde $\mathrm{N}$ é o número de intervalos no qual a amostra está dividida.

Comparando-se a entropia de cada intervalo à entropia máxima do sistema, facilmente se obtém o grau de desorganização do sistema $\left(H / H^{\max }\right)$, e consequentemente a organização $\left(1-H / H^{\max }\right)$. Por fim, a combinação de ambos gera a Complexidade SDL:

$$
\mathrm{C}_{S D L}=\left(1-H / H^{\max }\right)^{\alpha}\left(H / H^{\max }\right)^{\beta}
$$

onde $\alpha$ e $\beta$ são parâmetros arbitrários, também definidos por meio de experimentação (na maioria dos casos se usa $\alpha=\beta=0,5$, ou $\alpha=\beta=1)^{28}$.

Para a Complexidade LMC, o grau de desorganização do sistema citado anteriormente é substituído pelo desequilíbrio:

$$
D=\sum_{i=1}^{N}\left(p_{i}-1 / N\right)^{2}
$$

Combinando-se a mesma entropia medida anteriormente com a desorganização obtém-se a medida de Complexidade LMC:

$$
C_{L M C}=H * D=-\left(K \sum_{i=1}^{N} p_{i} \ln p_{i}\right)\left(\sum_{i=1}^{N}\left(p_{i}-1 / N\right)^{2}\right)
$$

\footnotetext{
${ }^{28}$ Aqui optou-se por $\alpha=\beta=1$, dando pesos iguais à organização e desorganização do sistema
} 
Calculadas as entropias para cada faixa de dados, esses são reorganizados em ordem temporal e plotados em gráficos, o que permite a análise visual da série como um todo. Desta forma, os eventos de crises são facilmente identificados.

\subsubsection{Análise Ex-Ante}

A segunda fase da análise consiste em separar os principais eventos de crise de cada série e "voltar no tempo" para o início de cada evento. Pergunta-se: com a informação disponível até aquele momento seria possível identificar que uma crise estava se formando?

Aqui, o início de cada evento de crise é definido como o primeiro quarto entre o mínimo e o máximo ${ }^{29}$ local. Em termos práticos, calcula-se a distância entre mínimo e máximo e divide-se por quatro, tomando-se a primeira parte. Assim, a amostra é cortada no início da crise, e todos os cálculos são refeitos, utilizando-se os dados do início da série até o ponto de corte. Se o nível da Complexidade, ao final da amostra, está localizado abaixo do mínimo previamente definido, quer dizer que o evento de crise seria identificado logo em seu início, permitindo que providências para redução do risco fossem tomadas a tempo de evitar-se maiores perdas financeiras.

O Gráfico 12 a seguir ilustra a análise ex-ante para a crise Subprime na série do Ibovespa. A série plotada em cinza (localizada embaixo da série em preto) é constituída pela amostra inteira até o auge da crise, já a série plotada em preto tem fim no ponto de corte no início da crise, conforme descrito acima.

\footnotetext{
${ }^{29}$ Ou entre o máximo e o mínimo, no caso do lbovespa
} 
Gráfico 12 - Ibovespa - Crise Subprime

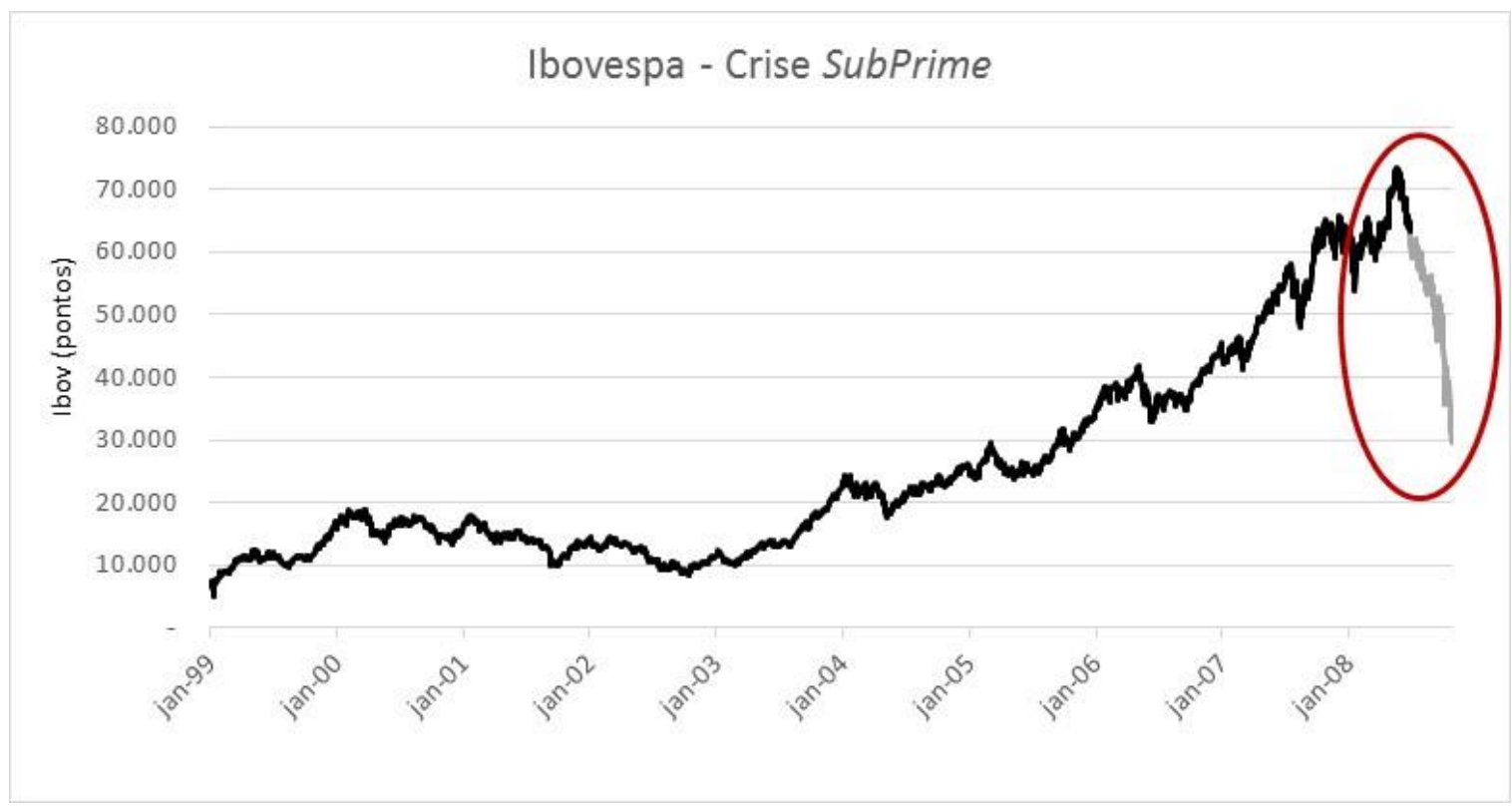

Fonte: elaborado pela autora

\subsection{Resultados}

\subsubsection{Câmbio}

Conforme descrito na seção de metodologia, o cálculo da Complexidade se inicia com a divisão da série de dados em intervalos equidistantes. O número de intervalos é decidido por meio de experimentação. Neste estudo foram testadas a divisão da amostra em 8, 16, 32 e 64 intervalos $^{30}$. Os gráficos abaixo mostram os resultados de cada divisão. 
Gráfico 13 - Complexidade da Taxa de Câmbio, 8 intervalos

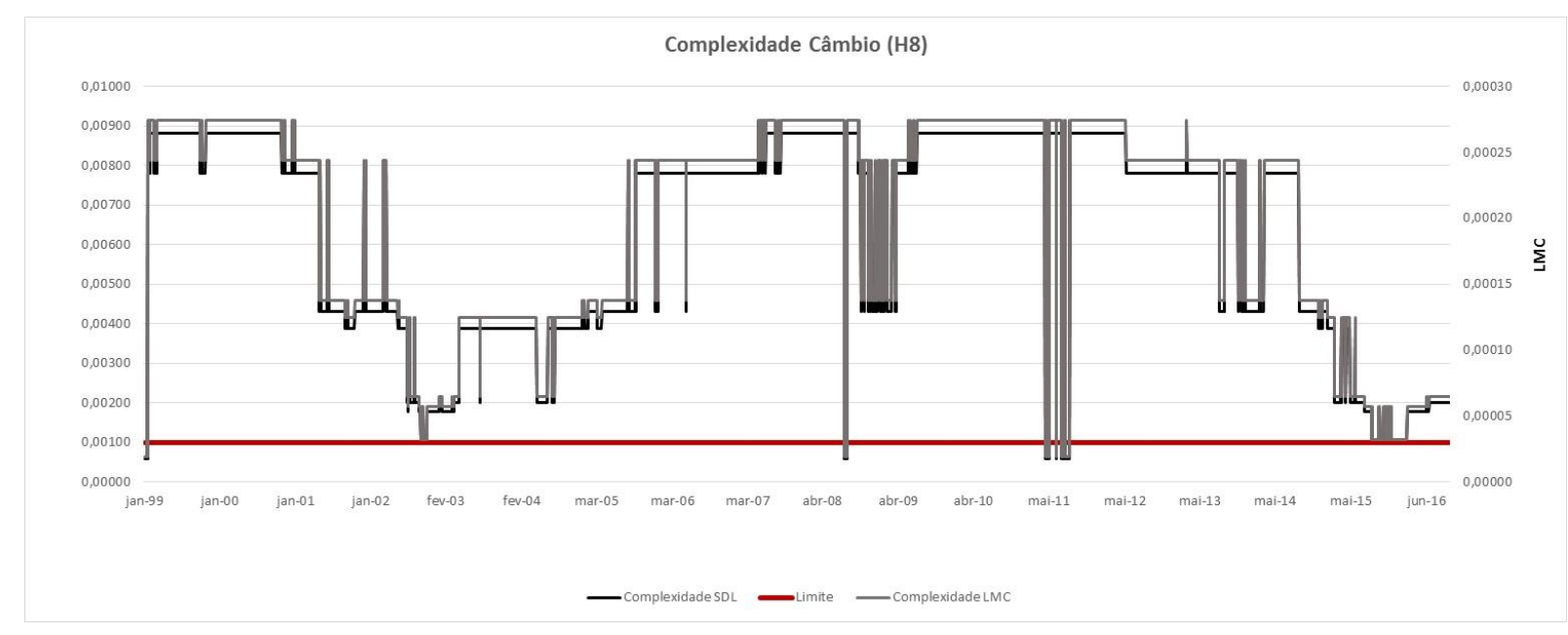

Fonte: elaborado pela autora

Gráfico 14 - Complexidade da Taxa de Câmbio, 16 intervalos

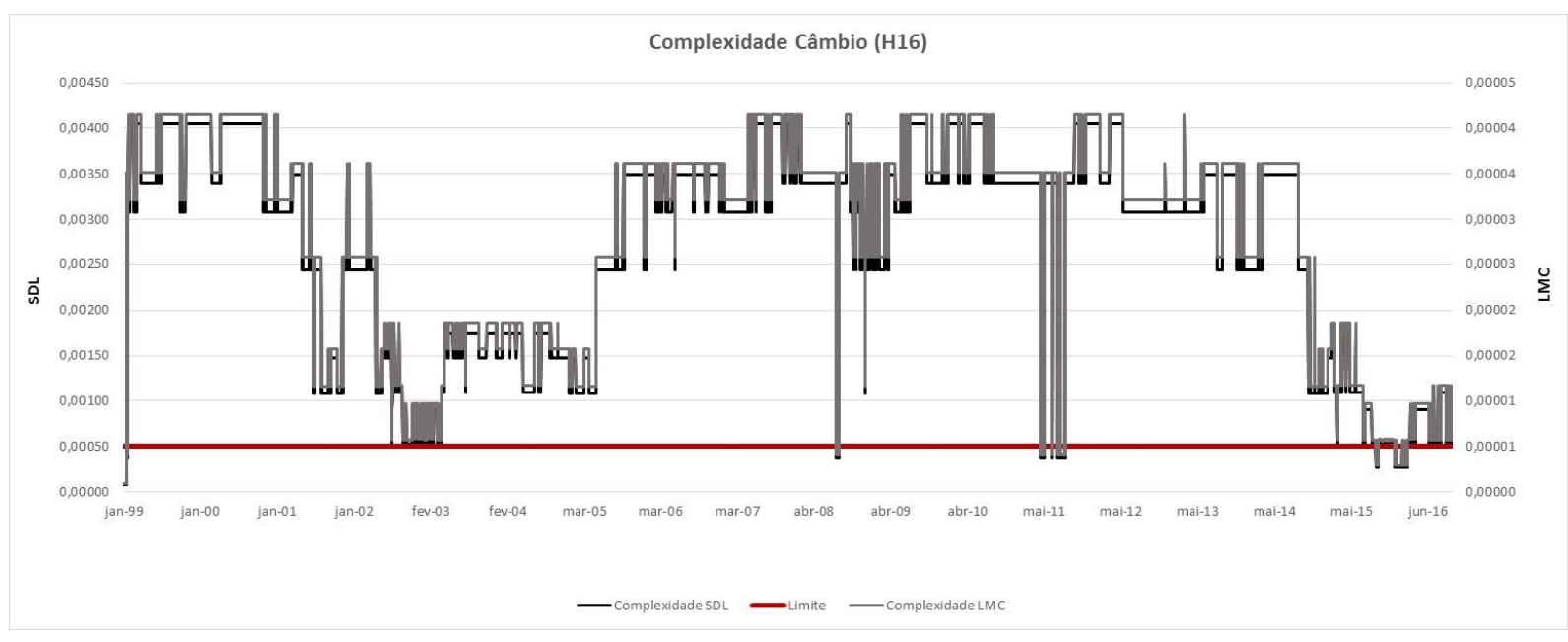

Fonte: elaborado pela autora 
Gráfico 15 - Complexidade da Taxa de Câmbio, 32 intervalos

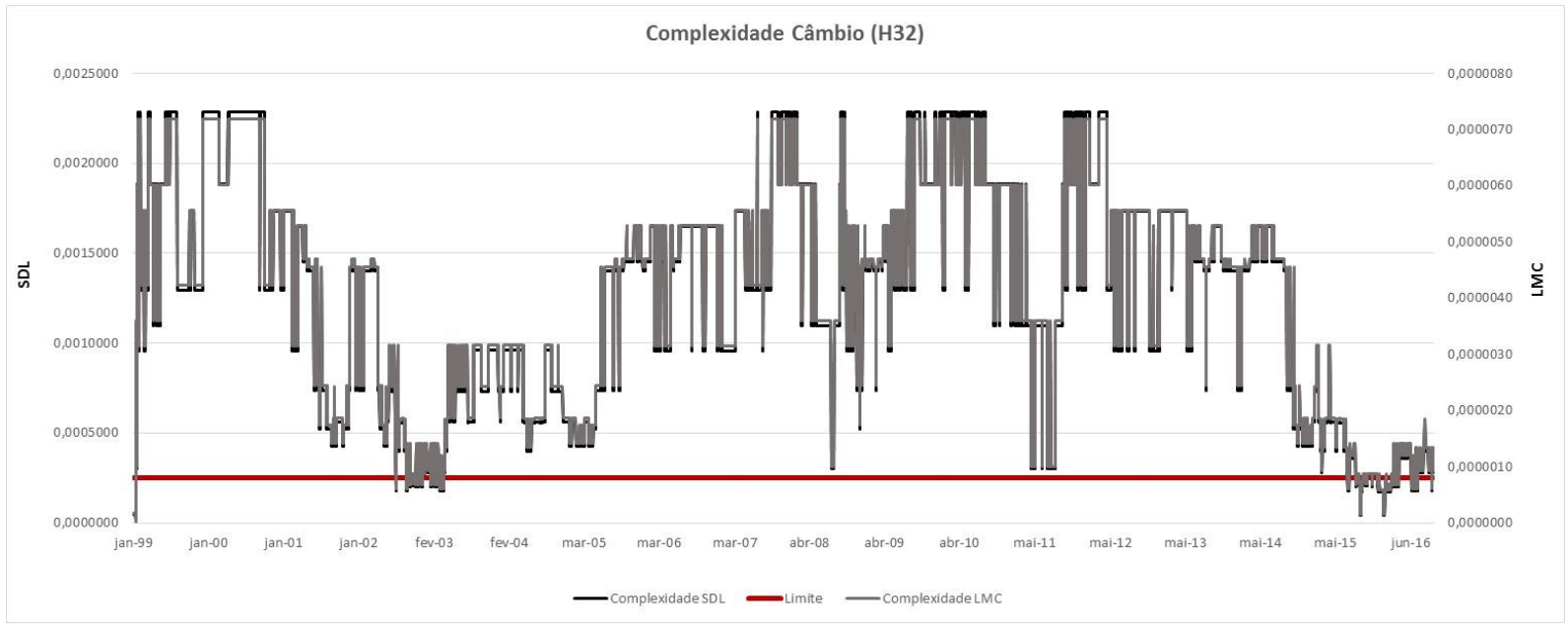

Fonte: elaborado pela autora

Gráfico 16 - Complexidade da Taxa de Câmbio, 64 intervalos

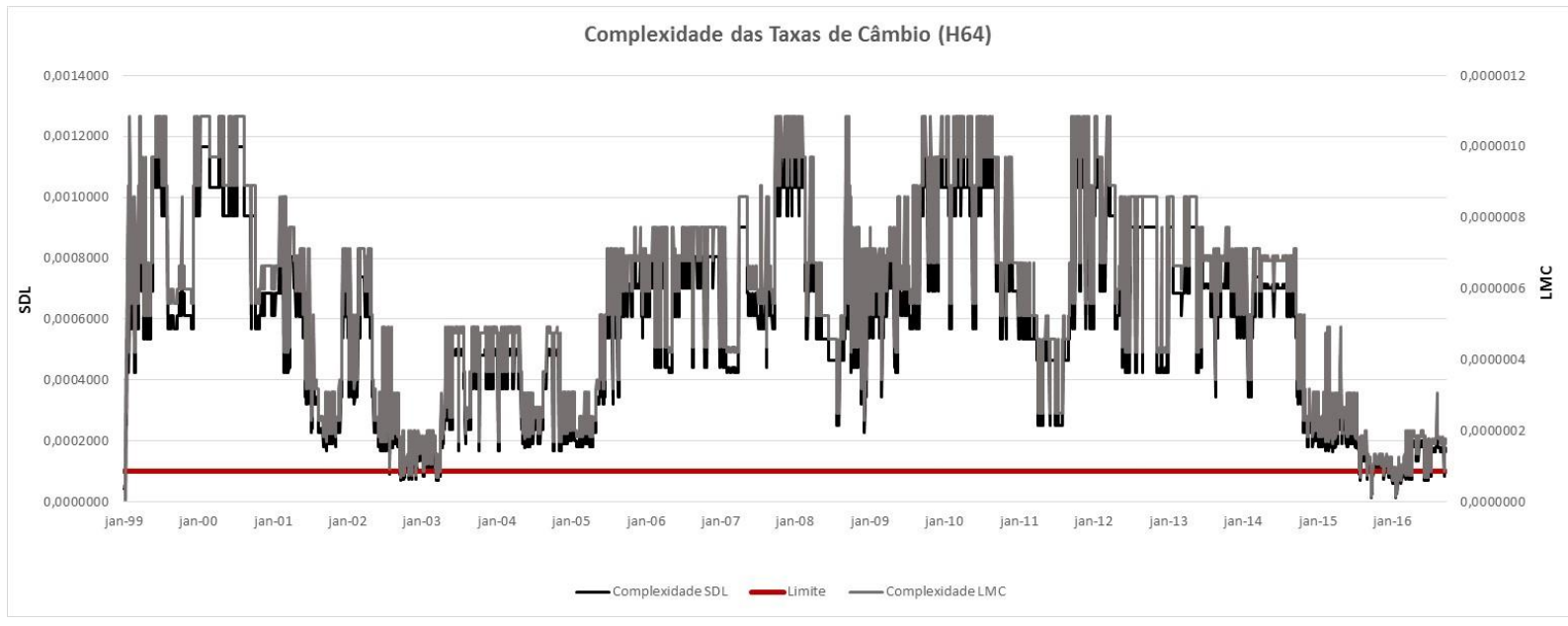

Fonte: elaborado pela autora

Comparando-se os gráficos, é possível observar que quanto maior o número de intervalos, maior a granularidade dos resultados, como se poderia esperar. $O$ limite inferior estabelecido para a detecção de crises também fica menor à medida que o número de intervalos aumenta. Porém, também existe um limite máximo para o número de intervalos. Quanto maior for este número, menor a amplitude de cada 
intervalo, acarretando em poucas ou nenhuma observação, e zero probabilidade de ocorrência. Para a série do câmbio, por exemplo, na divisão em 64 intervalos não foram observados dados para 4 intervalos. Ainda assim, os 64 intervalos apresentam a melhor granularidade, e por isso foram escolhidos para a segunda etapa dos cálculos, aqui definida como análise ex-ante.

Primeiramente, é necessário analisar os resultados encontrados na aplicação das medidas de Complexidade LMC e SDL para a série como um todo. Desta forma, pode-se estabelecer o limite inferior que define um evento como crise ou não: eventos nos quais a medida de Complexidade localiza-se abaixo do limite são classificados como crise. Detectados os eventos de crise, as amostras pré-crise são separadas e os cálculos são refeitos.

A Tabela 1 a seguir resume os resultados encontrados para os 64 intervalos aplicados à amostra das taxas de câmbio como um todo. Após calculadas as medidas de Complexidade para cada intervalo, os dados são organizados novamente em ordem temporal, e podem ser observados no Gráfico 16 acima. O menor valor encontrado tanto para Complexidade LMC quanto para a SDL localiza-se no intervalo número 5 - H5, seguido por H3, H64, H63, H1 e H62. Todos estes valores estão abaixo do limite estabelecido de 0,0001 para a Complexidade SDL e 0,0000001 para a Complexidade LMC, e coincidem com os eventos em janeiro de 1999, setembro de 2015, e janeiro de 2016, correspondentes à Crise Cambial e à Crise do Governo Dilma, respectivamente. Num nível um pouco acima estão os intervalos $\mathrm{H} 48, \mathrm{H} 54$, $\mathrm{H} 60, \mathrm{H} 46, \mathrm{H} 47$ e H61. Estes ainda estão abaixo do limite e coincidem com os eventos que aconteceram ao final do ano de 2002 e início de 2003 (Crise da Eleição do Lula), e final de 2015 e início de 2016 (Crise do Governo Dilma, novamente). Estes eventos estão destacados no Gráfico 17, exibido após a tabela de resultados.

Desta forma, fica claro que os eventos com maior impacto na série das taxas de câmbio dólar-real foram a Crise Cambial de 1999, A Crise da Eleição do Lula em 2002 e a Crise do Governo Dilma em 2015 e 2016. O primeiro evento não permite a análise ex-ante, já que não há informação disponível nos meses que antecederam a crise, pois nesta época o câmbio ainda não era flutuante. Cabe aqui então a análise ex-ante dos outros dois eventos. 
Tabela 1 - Complexidade da Taxa de Câmbio, 64 intervalos

\begin{tabular}{|c|c|c|c|c|c|c|}
\hline Intervalo & Min. & Max. & Num. Ocorrências & Probabilidade & Complexidade LMC & Complexidade SDL \\
\hline H1 & 1,2070 & 1,2534 & 7 & $0,16 \%$ & 0,0000000432 & 0,0000425975 \\
\hline $\mathrm{H} 2$ & 1,2534 & 1,2998 & 0 & $0,00 \%$ & NA & NA \\
\hline H3 & 1,2998 & 1,3463 & 2 & $0,05 \%$ & 0,0000000138 & 0,0000135522 \\
\hline $\mathrm{H} 4$ & 1,3463 & 1,3927 & 0 & $0,00 \%$ & NA & NA \\
\hline H5 & 1,3927 & 1,4391 & 1 & $0,02 \%$ & 0,0000000073 & 0,0000071582 \\
\hline $\mathrm{H} 6$ & 1,4391 & 1,4855 & 0 & $0,00 \%$ & NA & NA \\
\hline $\mathrm{H} 7$ & 1,4855 & 1,5320 & 0 & $0,00 \%$ & NA & NA \\
\hline H8 & 1,5320 & 1,5784 & 50 & $1,15 \%$ & 0,0000002502 & 0,0002500287 \\
\hline $\mathrm{H} 9$ & 1,5784 & 1,6248 & 101 & $2,32 \%$ & 0,0000004593 & 0,0004658222 \\
\hline H10 & 1,6248 & 1,6712 & 118 & $2,71 \%$ & 0,0000005239 & 0,0005340773 \\
\hline $\mathrm{H} 11$ & 1,6712 & 1,7176 & 159 & $3,65 \%$ & 0,0000006721 & 0,0006934119 \\
\hline H12 & 1,7176 & 1,7641 & 251 & $5,75 \%$ & 0,0000009723 & 0,0010311578 \\
\hline $\mathrm{H} 13$ & 1,7641 & 1,8105 & 289 & $6,63 \%$ & 0,0000010857 & 0,0011646783 \\
\hline H14 & 1,8105 & 1,8569 & 225 & $5,16 \%$ & 0,0000008914 & 0,0009379811 \\
\hline H15 & 1,8569 & 1,9033 & 127 & $2,91 \%$ & 0,0000005574 & 0,0005696488 \\
\hline H16 & 1,9033 & 1,9498 & 138 & $3,16 \%$ & 0,0000005975 & 0,0006126467 \\
\hline H17 & 1,9498 & 1,9962 & 157 & $3,60 \%$ & 0,0000006651 & 0,0006857897 \\
\hline $\mathrm{H} 18$ & 1,9962 & 2,0426 & 215 & $4,93 \%$ & 0,0000008595 & 0,0009017088 \\
\hline H19 & 2,0426 & 2,0890 & 91 & $2,09 \%$ & 0,0000004202 & 0,0004249461 \\
\hline $\mathrm{H} 2 \mathrm{O}$ & 2,0890 & 2,1354 & 95 & $2,18 \%$ & 0,0000004359 & 0,0004413661 \\
\hline H21 & 2,1354 & 2,1819 & 189 & $4,33 \%$ & 0,0000007744 & 0,0008061584 \\
\hline $\mathrm{H} 22$ & 2,1819 & 2,2283 & 161 & $3,69 \%$ & 0,0000006790 & 0,0007010201 \\
\hline $\mathrm{H} 23$ & 2,2283 & 2,2747 & 165 & $3,78 \%$ & 0,0000006929 & 0,0007161953 \\
\hline $\mathrm{H} 24$ & 2,2747 & 2,3211 & 137 & $3,14 \%$ & 0,0000005939 & 0,0006087585 \\
\hline $\mathrm{H} 25$ & 2,3211 & 2,3675 & 171 & $3,92 \%$ & 0,0000007136 & 0,0007388576 \\
\hline $\mathrm{H} 26$ & 2,3675 & 2,4140 & 119 & $2,73 \%$ & 0,0000005277 & 0,0005380480 \\
\hline $\mathrm{H} 27$ & 2,4140 & 2,4604 & 72 & $1,65 \%$ & 0,0000003436 & 0,0003455395 \\
\hline $\mathrm{H} 28$ & 2,4604 & 2,5068 & 66 & $1,51 \%$ & 0,0000003187 & 0,0003199173 \\
\hline $\mathrm{H} 29$ & 2,5068 & 2,5532 & 45 & $1,03 \%$ & 0,0000002281 & 0,0002276438 \\
\hline H30 & 2,5532 & 2,5997 & 48 & $1,10 \%$ & 0,0000002414 & 0,0002411095 \\
\hline H31 & 2,5997 & 2,6461 & 35 & $0,80 \%$ & 0,0000001828 & 0,0001819122 \\
\hline H32 & 2,6461 & 2,6925 & 39 & $0,89 \%$ & 0,0000002012 & 0,0002003724 \\
\hline H33 & 2,6925 & 2,7389 & 64 & $1,47 \%$ & 0,0000003103 & 0,0003113108 \\
\hline H34 & 2,7389 & 2,7853 & 37 & $0,85 \%$ & 0,0000001920 & 0,0001911722 \\
\hline H35 & 2,7853 & 2,8318 & 32 & $0,73 \%$ & 0,0000001689 & 0,0001679025 \\
\hline H36 & 2,8318 & 2,8782 & 105 & $2,41 \%$ & 0,0000004747 & 0,0004820158 \\
\hline H37 & 2,8782 & 2,9246 & 110 & $2,52 \%$ & 0,0000004938 & 0,0005021394 \\
\hline H38 & 2,9246 & 2,9710 & 78 & $1,79 \%$ & 0,0000003681 & 0,0003708847 \\
\hline H39 & 2,9710 & 3,0175 & 47 & $1,08 \%$ & 0,0000002370 & 0,0002366328 \\
\hline $\mathrm{H} 40$ & 3,0175 & 3,0639 & 54 & $1,24 \%$ & 0,0000002676 & 0,0002677359 \\
\hline H41 & 3,0639 & 3,1103 & 37 & $0,85 \%$ & 0,0000001920 & 0,0001911722 \\
\hline H42 & 3,1103 & 3,1567 & 63 & $1,44 \%$ & 0,0000003061 & 0,0003069946 \\
\hline $\mathrm{H} 43$ & 3,1567 & 3,2031 & 35 & $0,80 \%$ & 0,0000001828 & 0,0001819122 \\
\hline H44 & 3,2031 & 3,2496 & 34 & $0,78 \%$ & 0,0000001782 & 0,0001772587 \\
\hline H45 & 3,2496 & 3,2960 & 31 & $0,71 \%$ & 0,0000001642 & 0,0001631987 \\
\hline H46 & 3,2960 & 3,3424 & 15 & $0,34 \%$ & 0,0000000859 & 0,0000849752 \\
\hline H47 & 3,3424 & 3,3888 & 16 & $0,37 \%$ & 0,0000000910 & 0,0000900706 \\
\hline H48 & 3,3888 & 3,4353 & 12 & $0,28 \%$ & 0,0000000703 & 0,0000694572 \\
\hline H49 & 3,4353 & 3,4817 & 25 & $0,57 \%$ & 0,0000001357 & 0,0001345797 \\
\hline H50 & 3,4817 & 3,5281 & 36 & $0,83 \%$ & 0,0000001875 & 0,0001865499 \\
\hline H51 & 3,5281 & 3,5745 & 35 & $0,80 \%$ & 0,0000001828 & 0,0001819122 \\
\hline H52 & 3,5745 & 3,6209 & 39 & $0,89 \%$ & 0,0000002012 & 0,0002003724 \\
\hline H53 & 3,6209 & 3,6674 & 19 & $0,44 \%$ & 0,0000001062 & 0,0001051576 \\
\hline H54 & 3,6674 & 3,7138 & 13 & $0,30 \%$ & 0,0000000755 & 0,0000746714 \\
\hline H55 & 3,7138 & 3,7602 & 18 & $0,41 \%$ & 0,0000001012 & 0,0001001599 \\
\hline H56 & 3,7602 & 3,8066 & 25 & $0,57 \%$ & 0,0000001357 & 0,0001345797 \\
\hline H57 & 3,8066 & 3,8530 & 20 & $0,46 \%$ & 0,0000001112 & 0,0001101262 \\
\hline H58 & 3,8530 & 3,8995 & 23 & $0,53 \%$ & 0,0000001260 & 0,0001248715 \\
\hline H59 & 3,8995 & 3,9459 & 19 & $0,44 \%$ & 0,0000001062 & 0,0001051576 \\
\hline $\mathrm{H} 60$ & 3,9459 & 3,9923 & 14 & $0,32 \%$ & 0,0000000807 & 0,0000798430 \\
\hline H61 & 3,9923 & 4,0387 & 17 & $0,39 \%$ & 0,0000000961 & 0,0000951315 \\
\hline $\mathrm{H} 62$ & 4,0387 & 4,0852 & 10 & $0,23 \%$ & 0,0000000596 & 0,0000588866 \\
\hline $\mathrm{H} 63$ & 4,0852 & 4,1316 & 4 & $0,09 \%$ & 0,0000000259 & 0,0000255757 \\
\hline H64 & 4,1316 & 4,1780 & 2 & $0,05 \%$ & 0,0000000138 & 0,0000135522 \\
\hline
\end{tabular}

Fonte: elaborado pela autora 
Gráfico 17 - Complexidade da Taxa de Câmbio e Eventos de Crise, 64 intervalos

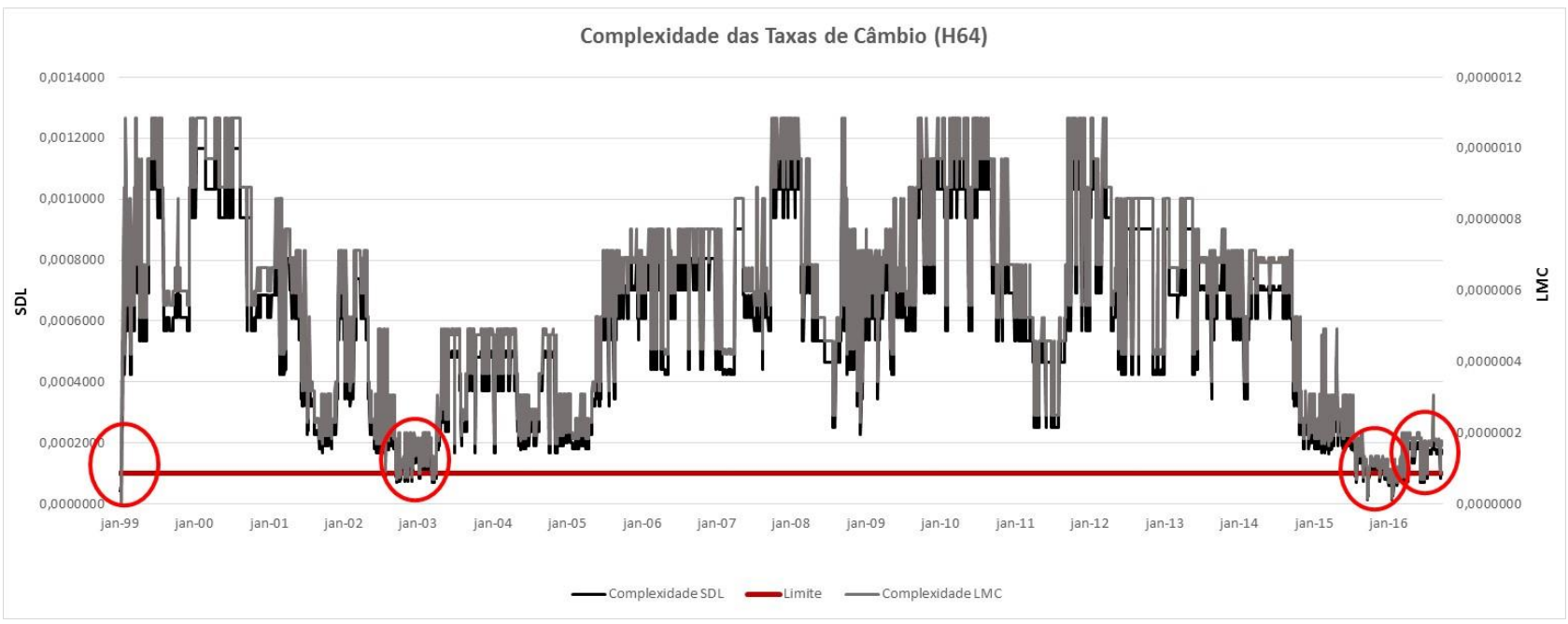

Fonte: elaborado pela autora

\subsubsection{Câmbio: Crise Pré-Eleição do Lula}

Pode-se dizer que a escalada do dólar na Crise da eleição do Lula teve início em 10 de abril de 2002, partindo do mínimo local de BRL/USD 2,2650; e atingindo seu auge em 23 de outubro de 2002, o máximo local de 3,9510. Desta forma, o primeiro quarto da subida da taxa de câmbio encontra-se por volta de 2,69, entre as datas de 10 e 11 de Junho de 2002. Este é então o ponto de corte para a análise exante deste evento. Estes pontos estão ilustrados no Gráfico 18 abaixo, onde comparase a amostra desde o início, em janeiro de 1999, até o auge da crise (plotada em cinza) com a amostra que tem fim no ponto de corte (plotada em preto). 
Gráfico 18 - Taxa de Câmbio - Crise Pré-Eleição do Lula: amostras pré-crise e crise

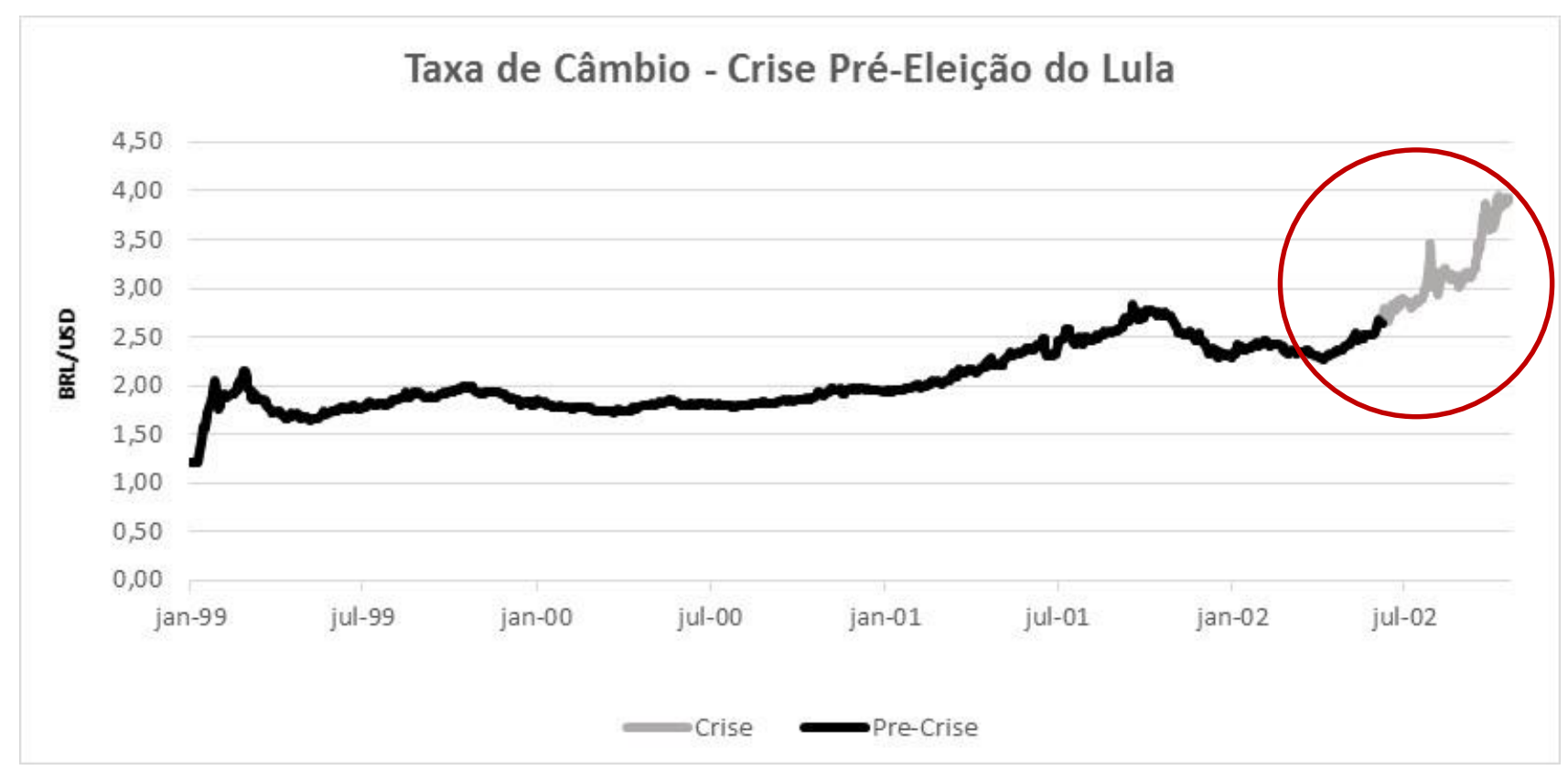

Fonte: elaborado pela autora

Gráfico 19 - Complexidade da Taxa de Câmbio - Crise Pré-Eleição do Lula

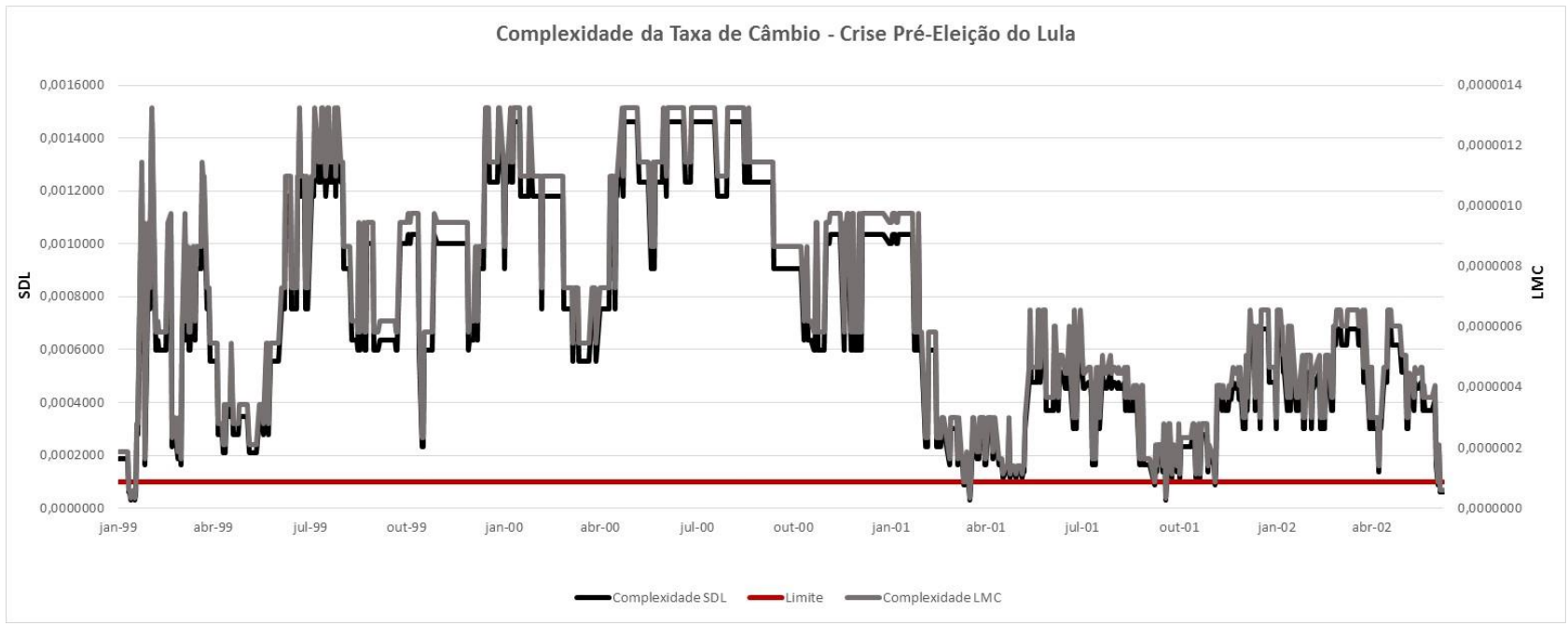

Fonte: elaborado pela autora 
Aplicando-se os limites inferiores estabelecidos anteriormente (durante a análise da amostra inteira), nota-se que ambas as medidas de Complexidade ultrapassam os limites em quatro momentos distintos.

O primeiro acontece logo no início da série, em janeiro de 1999, evento aqui definido como a Crise Cambial de 1999.

O segundo momento ocorre por volta de março de 2001, causado pela preocupação do investidor estrangeiro em relação ao cenário político do Brasil, e principalmente à crise econômica da Argentina, de acordo com o relatório de política cambial do Banco Central do Brasil (2001):

"No início de março, a troca de comando no ministério da economia do país vizinho - López Murphy no lugar de Machinea - chegou a trazer alguma calma às cotações cambiais, mas as análises pessimistas voltaram quando o novo ministro apresentou pacote de corte de gastos, julgado inexequível de início, principalmente em função da forte oposição política. Os desdobramentos da rejeição ao forte ajuste nas contas públicas proposto pelo novo ministro acabaram por forçar seu pedido de demissão no dia 20 de março, sendo substituído por Domingo Cavallo, originalmente conhecido por ser autor do Plano de Conversibilidade adotado na Argentina em 1991. Considerado pelo mercado como a última tentativa de ajuste para o país, o novo ministro anunciou logo de início o 'Plano de Competitividade', buscando restabelecer a confiança dos investidores domésticos e internacionais na economia da Argentina. Foram várias as medidas adotadas para a superação da crise, sempre e principalmente voltadas para contenção do déficit fiscal e retomada do crescimento. Entre duvidoso e esperançoso, o mercado encerrou o trimestre em compasso de espera frente aos desdobramentos das medidas adotadas na Argentina e seus reflexos no Brasil, mantendo pressão firme sobre as cotações do dólar".

O terceiro momento em que as medidas de Complexidade caem abaixo dos limites estabelecidos ocorre em setembro de 2001, causado pelo ataque terrorista às Torres Gêmeas em Nova lorque, evento de choque mundial, porém passageiro, conforme descrito no capítulo anterior.

Por fim, o quarto momento é o evento que nesta seção está sendo testado, a Crise da Eleição do Lula, tendo início em meados de 2002. Como as medidas de Complexidade ultrapassam os limites inferiores da série que tem como ponto de corte o primeiro quarto deste evento, pode-se concluir que, neste caso, a crise poderia ter sido detectada logo em seu início, bem antes de atingir seu auge. 


\subsubsection{Câmbio: Crise do Governo Dilma}

Esta é a crise mais longa de toda a amostra, e é também quando a taxa de câmbio dólar-real atinge o máximo geral da série, 4,1780, em setembro de 2015. A escalada do câmbio no Governo Dilma começou um ano antes, por volta de setembro de 2014, quando o cenário político começou a apontar mais claramente para a reeleição da candidata.

Este, porém, não foi o início definido para este evento, já que um ano é um intervalo de tempo considerável, e houve um movimento de baixa por volta de abril de 2015, o que comprometeria de certa forma os resultados. Assim, para a análise ex-ante, considerou-se o início do evento de crise no mínimo local, 2,9170, em 27 de abril de 2015; e o auge da crise no ponto de máximo geral, citado no parágrafo anterior. Desta forma, o primeiro quarto da subida localiza-se próximo a BRL/USD 3,23; patamar atingido pela primeira vez (durante este evento) em 08 de julho de 2015. Este é então o ponto de corte desta amostra que, assim como as demais, tem início em janeiro de 1999, e está ilustrada no Gráfico 20 abaixo.

Gráfico 20 - Taxa de Câmbio - Crise do Governo Dilma: amostras pré-crise e crise

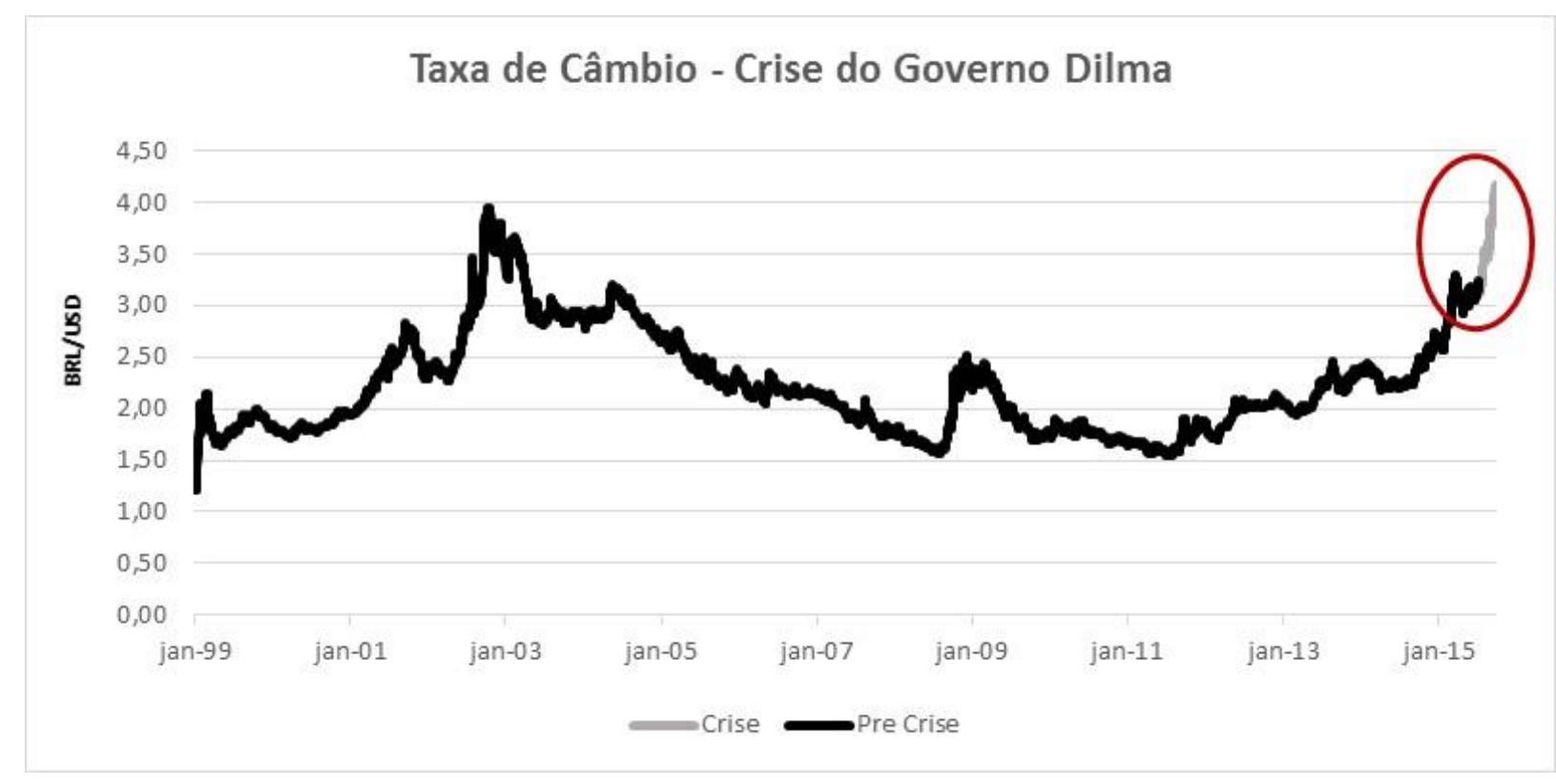

Fonte: elaborado pela autora 
Aplicados os mesmos limites anteriores, nesta amostra destacam-se cinco momentos nos quais as medidas de Complexidade ultrapassaram os limites de baixa.

Os dois primeiros momentos coincidem com o primeiro e o último momento da amostra estudada na seção anterior, correspondentes aos eventos da Crise Cambial e a Crise Pré-Eleição do Lula.

O terceiro momento acontece exatamente em maio de 2004, data em que o banco de investimento americano JP Morgan Chase rebaixou os títulos da dívida brasileira, recomendando que os investidores reduzissem sua exposição aos mercados emergentes, dada a possibilidade de o Federal Reserve ${ }^{31}$ aumentar as taxas de juros americana, diminuindo a atratividade dos títulos de dívida pública dos mercados emergentes (FOLHA ONLINE, 2004). A iminente alta da taxa de juros americana também provocou aumento do risco Brasil, conforme pode-se observar na série do $C D S$ soberano do país, na seção que descreve os dados deste trabalho.

O quarto momento é bastante distinto dos demais. Ao invés de ser causado por uma alta da taxa dólar-real, este evento é marcado pela abrupta baixa da moeda americana frente à moeda nacional, pontualmente em 29 de julho de 2011. Nesta época, o dólar já vinha sofrendo pressão de baixa em esfera mundial, já que o Congresso Americano encontrava dificuldades em aprovar o orçamento para pagamento de dívidas do país. O risco de um default por parte do Governo Americano estava em franca ascensão. Porém, no Brasil, o dólar seguia valorizado, às custas de um imposto sobre operações com derivativos de câmbio, estabelecido pelo Governo local na tentativa de frear a desvalorização da moeda nacional e favorecer as exportações do País. Mas em 29 de julho de 2011, a pressão internacional foi maior, causando a queda taxa de câmbio dólar-real (ESTADÃO, 2011).

Por fim, o quinto momento em que as medidas de Complexidade caem abaixo dos limites estabelecidos corresponde ao evento em foco nesta seção, definido como a Crise do Governo Dilma. Pode-se notar que a Complexidade ultrapassa o limite duas vezes durante este evento, sendo que a primeira acontece antes do que foi considerado como o primeiro quarto da escalada do dólar, e a segunda acontece durante este primeiro quarto. Desta forma, assim como na seção anterior, mostra-se

\footnotetext{
${ }^{31}$ Banco Central dos Estados Unidos da América
} 
que seria possível a identificação da crise antes que ela atingisse seu ápice, cumprindo com o objetivo principal deste trabalho.

Gráfico 21 - Complexidade da Taxa de Câmbio - Crise do Governo Dilma

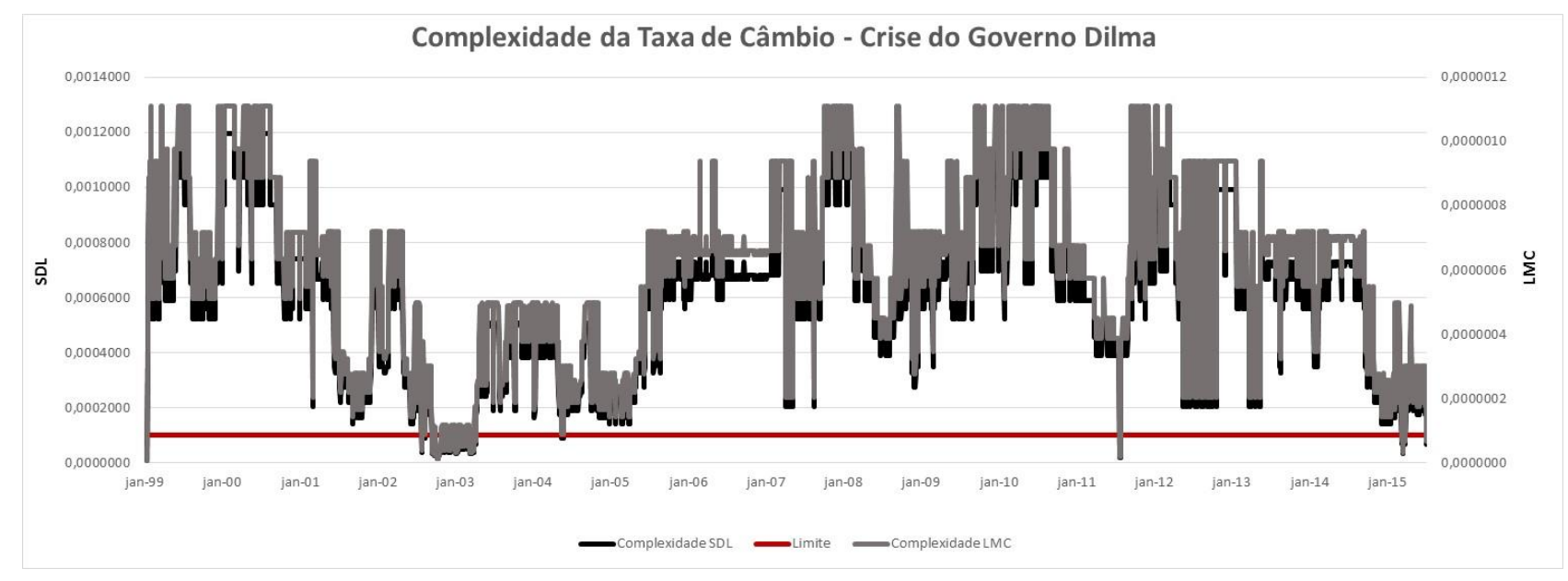

Fonte: elaborado pela autora

\subsubsection{Ibovespa}

Assim como na série do câmbio, a divisão da amostra em diferentes números de intervalos foi testada para a série do lbovespa. Novamente foram usados 8, 16, 32 e 64 intervalos, ilustrados nos gráficos abaixo. 
Gráfico 22 - Complexidade do Ibovespa, 8 intervalos

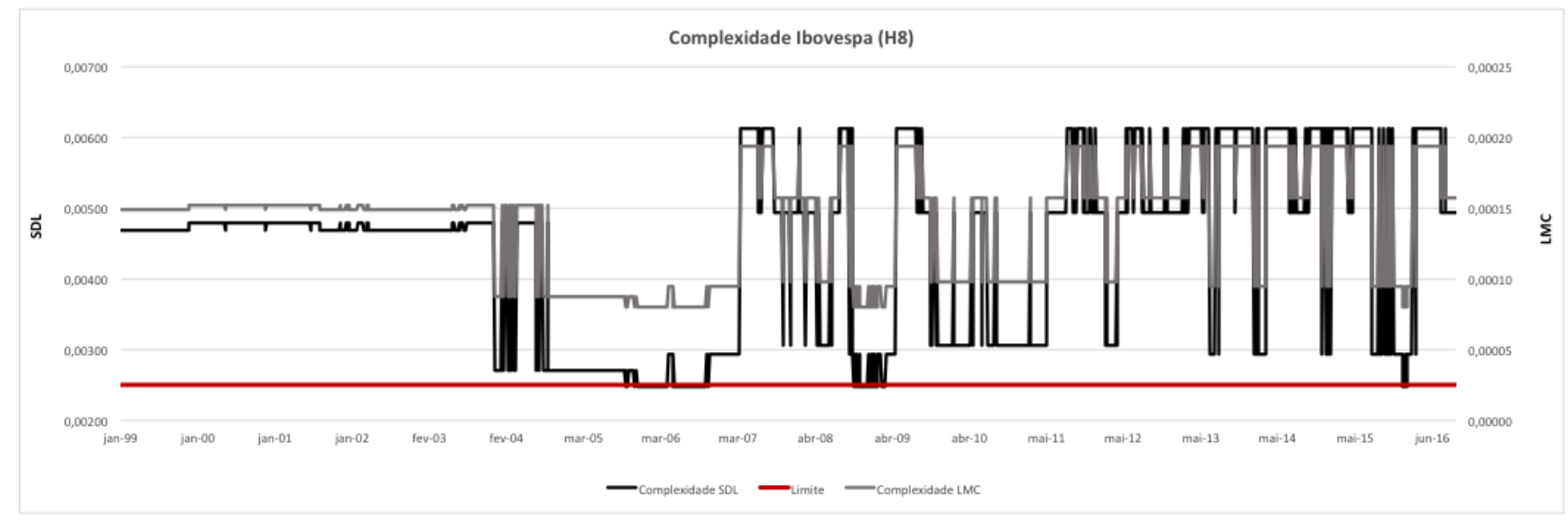

Fonte: elaborado pela autora

Gráfico 23 - Complexidade do Ibovespa, 16 intervalos

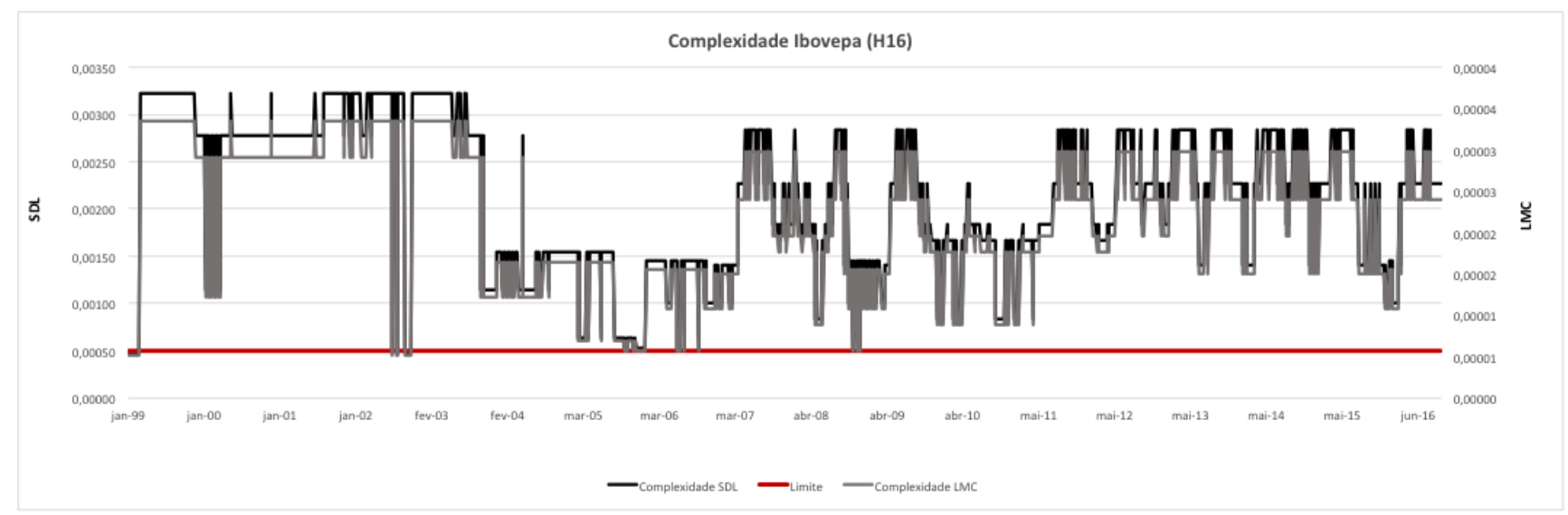

Fonte: elaborado pela autora 
Gráfico 24 - Complexidade do lbovespa, 32 intervalos

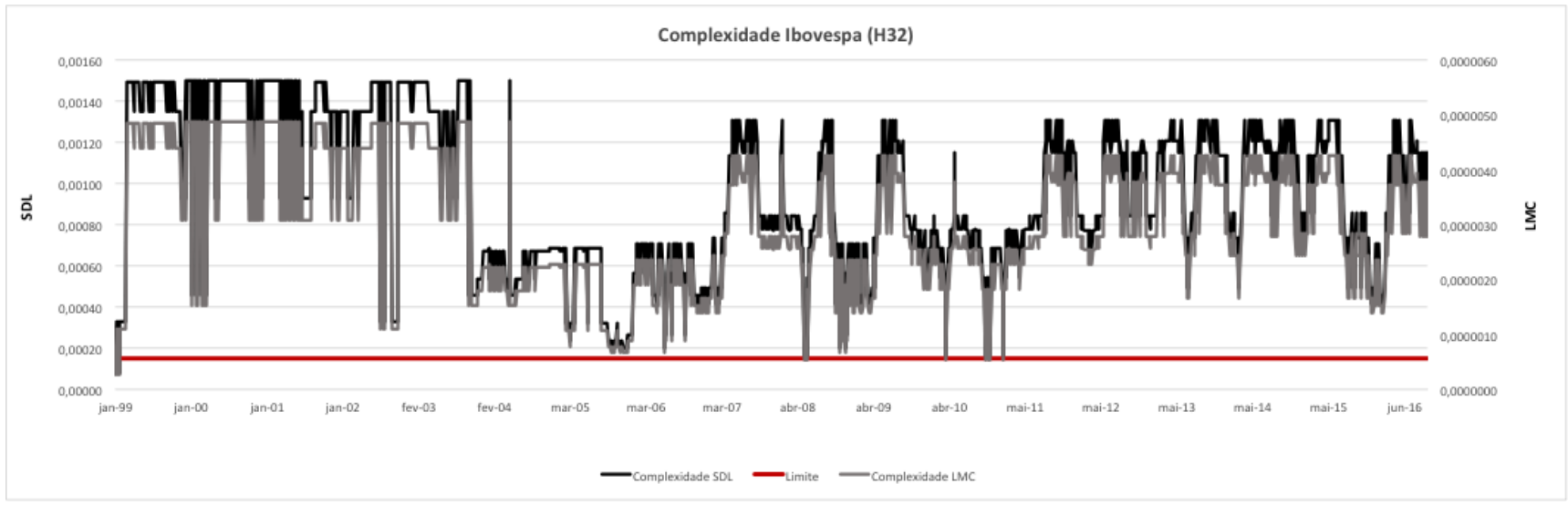

Fonte: elaborado pela autora

Gráfico 25 - Complexidade do Ibovespa, 64 intervalos

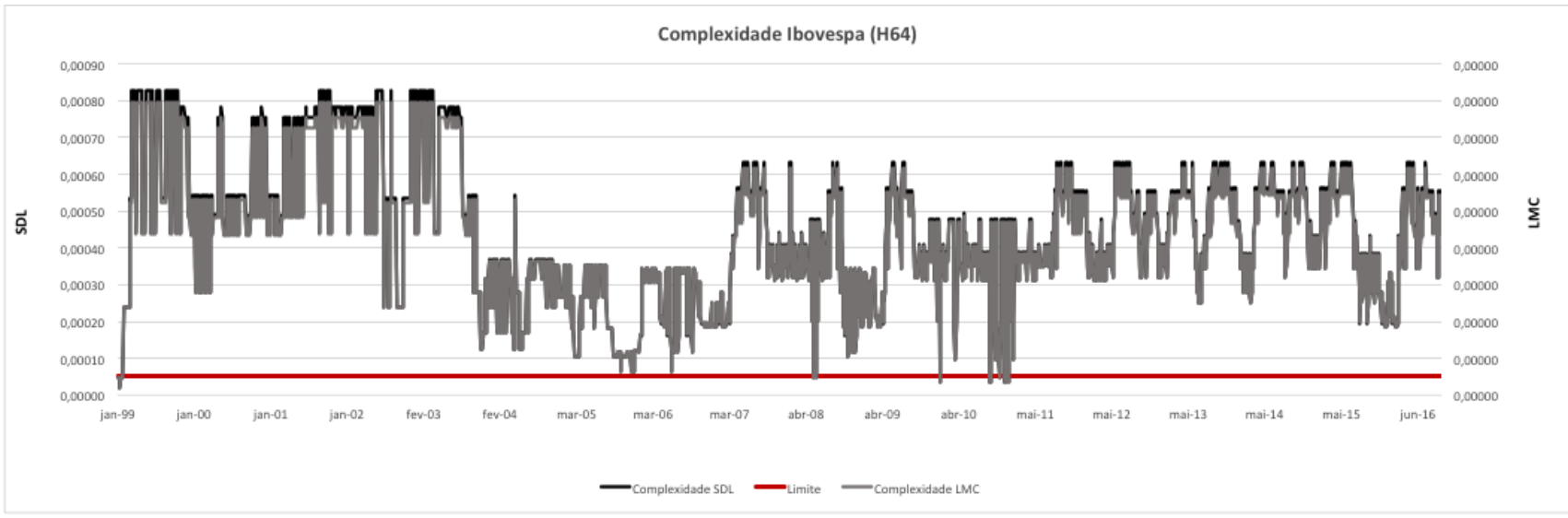

Fonte: elaborado pela autora

Novamente, a divisão em 64 intervalos mostrou-se mais eficiente que as demais opções, apresentando resultados com maior granularidade e, para a série do lbovespa, não foram encontrados intervalos sem observações. A Tabela 2 na página a seguir exibe os números encontrados no cálculo das medidas de Complexidade para os 64 intervalos. 
O ponto mais baixo da série, tanto para a Complexidade SDL quanto para a Complexidade LMC, localiza-se no primeiro intervalo - $\mathrm{H} 1$, que acontece logo no início da série, em janeiro de 1999, durante a Crise Cambial. Este é seguido por H60, que está localizado na segunda metade de 2010, quando os mercados financeiros mundiais ainda sofriam os impactos da Crise Subprime. Em seguida estão H2 e H3, apontando também para a Crise Cambial em 1999. Por fim, ainda abaixo dos limites de 0,00005 (Complexidade SDL) e 0,00000005 (Complexidade LMC), está H64, que é também reflexo da Crise Subprime, sendo encontrada por volta de maio de 2008 (máximo local antes da crise) e também novembro de 2010.

Os pontos descritos acima são destacados no Gráfico 26, logo após a tabela de resultados. Neste gráfico também estão destacados os demais eventos de crise analisados neste estudo: a Crise Pré-Eleição do Lula, e a Crise do Governo Dilma. Porém, as medidas de complexidade não ultrapassam os limites estabelecidos durante estes dois últimos eventos. Assim, o principal evento a ser estudado nesta série é a Crise Subprime ${ }^{32}$.

${ }^{32}$ A Crise Cambial não permite análise ex-ante, já que está localizada bem no início da série de dados. 
Tabela 2 - Complexidade do Ibovespa, 64 intervalos

\begin{tabular}{|c|c|c|c|c|c|c|}
\hline Intervalo & Min. & Max. & Num. Ocorrências & Probabilidade & Complexidade LMC & Comblexidade SDL \\
\hline H1 & $5.057,19$ & $6.126,87$ & 3 & $0,07 \%$ & 0,0000000199 & 0,0000196576 \\
\hline $\mathrm{H} 2$ & $6.126,87$ & $7.196,55$ & 8 & $0,18 \%$ & 0,0000000487 & 0,0000480938 \\
\hline H3 & $7.196,55$ & $8.266,23$ & 8 & $0,18 \%$ & 0,0000000487 & 0,0000480938 \\
\hline H4 & $8.266,23$ & $9.335,92$ & 47 & $1,08 \%$ & 0,0000002370 & 0,0002366328 \\
\hline H5 & $9.335,92$ & $10.405,60$ & 118 & $2,71 \%$ & 0,0000005239 & 0,0005340773 \\
\hline H6 & $10.405,60$ & $11.475,28$ & 195 & $4,47 \%$ & 0,0000007943 & 0,0008283756 \\
\hline H7 & $11.475,28$ & $12.544,96$ & 95 & $2,18 \%$ & 0,0000004359 & 0,0004413661 \\
\hline H8 & $12.544,96$ & $13.614,64$ & 183 & $4,20 \%$ & 0,0000007543 & 0,0007838353 \\
\hline H9 & $13.614,64$ & $14.684,32$ & 175 & $4,01 \%$ & 0,0000007272 & 0,0007539006 \\
\hline H10 & $14.684,32$ & $15.754,01$ & 107 & $2,45 \%$ & 0,0000004823 & 0,0004900807 \\
\hline H11 & $15.754,01$ & $16.823,69$ & 94 & $2,15 \%$ & 0,0000004320 & 0,0004372700 \\
\hline H12 & $16.823,69$ & $17.893,37$ & 120 & $2,75 \%$ & 0,0000005314 & 0,0005420140 \\
\hline H13 & $17.893,37$ & $18.963,05$ & 57 & $1,31 \%$ & 0,0000002805 & 0,0002809081 \\
\hline H14 & $18.963,05$ & $20.032,73$ & 23 & $0,53 \%$ & 0,0000001260 & 0,0001248715 \\
\hline H15 & $20.032,73$ & $21.102,41$ & 32 & $0,73 \%$ & 0,0000001689 & 0,0001679025 \\
\hline H16 & $21.102,41$ & $22.172,10$ & 65 & $1,49 \%$ & 0,0000003145 & 0,0003156183 \\
\hline H17 & $22.172,10$ & $23.241,78$ & 77 & $1,77 \%$ & 0,0000003641 & 0,0003666788 \\
\hline H18 & $23.241,78$ & $24.311,46$ & 47 & $1,08 \%$ & 0,0000002370 & 0,0002366328 \\
\hline H19 & $24.311,46$ & $25.381,14$ & 74 & $1,70 \%$ & 0,0000003518 & 0,0003540176 \\
\hline $\mathrm{H} 2 \mathrm{O}$ & $25.381,14$ & $26.450,82$ & 54 & $1,24 \%$ & 0,0000002676 & 0,0002677359 \\
\hline H21 & $26.450,82$ & $27.520,50$ & 35 & $0,80 \%$ & 0,0000001828 & 0,0001819122 \\
\hline $\mathrm{H} 22$ & $27.520,50$ & $28.590,19$ & 19 & $0,44 \%$ & 0,0000001062 & 0,0001051576 \\
\hline $\mathrm{H} 23$ & $28.590,19$ & $29.659,87$ & 19 & $0,44 \%$ & 0,0000001062 & 0,0001051576 \\
\hline H24 & $29.659,87$ & $30.729,55$ & 19 & $0,44 \%$ & 0,0000001062 & 0,0001051576 \\
\hline H25 & $30.729,55$ & $31.799,23$ & 21 & $0,48 \%$ & 0,0000001161 & 0,0001150672 \\
\hline H26 & $31.799,23$ & $32.868,91$ & 11 & $0,25 \%$ & 0,0000000650 & 0,0000641970 \\
\hline H27 & $32.868,91$ & $33.938,59$ & 22 & $0,50 \%$ & 0,0000001211 & 0,0001199819 \\
\hline $\mathrm{H} 28$ & $33.938,59$ & $35.008,28$ & 21 & $0,48 \%$ & 0,0000001161 & 0,0001150672 \\
\hline H29 & $35.008,28$ & $36.077,96$ & 31 & $0,71 \%$ & 0,0000001642 & 0,0001631987 \\
\hline H30 & $36.077,96$ & $37.147,64$ & 72 & $1,65 \%$ & 0,0000003436 & 0,0003455395 \\
\hline H31 & $37.147,64$ & $38.217,32$ & 69 & $1,58 \%$ & 0,0000003312 & 0,0003327645 \\
\hline H32 & $38.217,32$ & $39.287,00$ & 63 & $1,44 \%$ & 0,0000003061 & 0,0003069946 \\
\hline H33 & $39.287,00$ & $40.356,68$ & 42 & $0,96 \%$ & 0,0000002147 & 0,0002140674 \\
\hline H34 & $40.356,68$ & $41.426,36$ & 38 & $0,87 \%$ & 0,0000001966 & 0,0001957796 \\
\hline H35 & $41.426,36$ & $42.496,05$ & 36 & $0,83 \%$ & 0,0000001875 & 0,0001865499 \\
\hline H36 & $42.496,05$ & $43.565,73$ & 36 & $0,83 \%$ & 0,0000001875 & 0,0001865499 \\
\hline H37 & $43.565,73$ & $44.635,41$ & 38 & $0,87 \%$ & 0,0000001966 & 0,0001957796 \\
\hline H38 & $44.635,41$ & $45.705,09$ & 50 & $1,15 \%$ & 0,0000002502 & 0,0002500287 \\
\hline H39 & $45.705,09$ & $46.774,77$ & 57 & $1,31 \%$ & 0,0000002805 & 0,0002809081 \\
\hline $\mathrm{H} 40$ & $46.774,77$ & $47.844,45$ & 81 & $1,86 \%$ & 0,0000003803 & 0,0003834602 \\
\hline H41 & $47.844,45$ & $48.914,14$ & 72 & $1,65 \%$ & 0,0000003436 & 0,0003455395 \\
\hline H42 & $48.914,14$ & $49.983,82$ & 93 & $2,13 \%$ & 0,0000004281 & 0,0004331680 \\
\hline $\mathrm{H} 43$ & $49.983,82$ & $51.053,50$ & 103 & $2,36 \%$ & 0,0000004670 & 0,0004739298 \\
\hline H44 & $51.053,50$ & $52.123,18$ & 125 & $2,87 \%$ & 0,0000005500 & 0,0005617755 \\
\hline H45 & $52.123,18$ & $53.192,86$ & 124 & $2,84 \%$ & 0,0000005463 & 0,0005578322 \\
\hline H46 & $53.192,86$ & $54.262,54$ & 143 & $3,28 \%$ & 0,0000006155 & 0,0006320280 \\
\hline H47 & $54.262,54$ & $55.332,23$ & 123 & $2,82 \%$ & 0,0000005426 & 0,0005538845 \\
\hline H48 & $55.332,23$ & $56.401,91$ & 121 & $2,77 \%$ & 0,0000005351 & 0,0005459754 \\
\hline H49 & $56.401,91$ & $57.471,59$ & 123 & $2,82 \%$ & 0,0000005426 & 0,0005538845 \\
\hline H50 & $57.471,59$ & $58.541,27$ & 108 & $2,48 \%$ & 0,0000004862 & 0,0004941054 \\
\hline H51 & $58.541,27$ & $59.610,95$ & 95 & $2,18 \%$ & 0,0000004359 & 0,0004413661 \\
\hline H52 & $59.610,95$ & $60.680,63$ & 66 & $1,51 \%$ & 0,0000003187 & 0,0003199173 \\
\hline H53 & $60.680,63$ & $61.750,32$ & 74 & $1,70 \%$ & 0,0000003518 & 0,0003540176 \\
\hline H54 & $61.750,32$ & $62.820,00$ & 87 & $1,99 \%$ & 0,0000004043 & 0,0004084288 \\
\hline H55 & $62.820,00$ & $63.889,68$ & 74 & $1,70 \%$ & 0,0000003518 & 0,0003540176 \\
\hline H56 & $63.889,68$ & $64.959,36$ & 73 & $1,67 \%$ & 0,0000003477 & 0,0003497824 \\
\hline H57 & $64.959,36$ & $66.029,04$ & 64 & $1,47 \%$ & 0,0000003103 & 0,0003113108 \\
\hline H58 & $66.029,04$ & $67.098,72$ & 82 & $1,88 \%$ & 0,0000003843 & 0,0003876383 \\
\hline H59 & 6709872 & 6816840 & 76 & $174 \%$ & 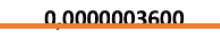 & 0.0003624657 \\
\hline $\mathrm{H} 60$ & 68.168 .40 & 69.238 .09 & 6 & $0.14 \%$ & 0.0000000375 & 0.0000370222 \\
\hline H61 & $69.238,09$ & $70.307,77$ & 104 & $2,38 \%$ & 0,0000004708 & 0,0004779754 \\
\hline $\mathrm{H} 62$ & $70.307,77$ & $71.377,45$ & 39 & $0,89 \%$ & 0,0000002012 & 0,0002003724 \\
\hline H63 & $71.377,45$ & $72.447,13$ & 17 & $0,39 \%$ & 0,0000000961 & 0,0000951315 \\
\hline $\mathrm{H} 64$ & $72.447,13$ & $73.516,81$ & 8 & $0,18 \%$ & 0,0000000487 & 0,0000480938 \\
\hline
\end{tabular}

Fonte: elaborado pela autora 
Gráfico 26 - Complexidade do lbovespa, 64 intervalos, e os eventos de crise

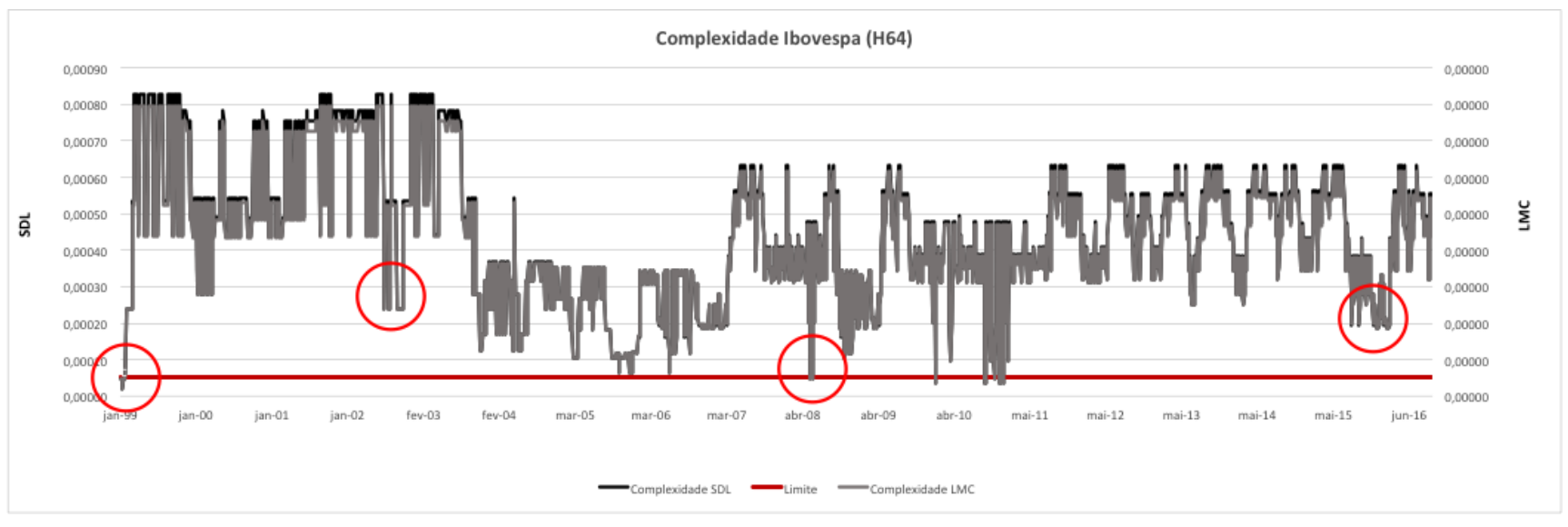

Fonte: elaborado pela autora

\subsubsection{1 lbovespa: Crise Subprime}

A Crise Subprime foi um longo evento, que começou a se desenvolver em meados de julho de 2007, teve seu auge em outubro de 2008, e se estendeu até final de 2010, pelo menos. A Bolsa Brasileira começou a sentir os efeitos da crise em meados de 2008, poucos meses após ter atingido o ponto máximo da série, no mês de maio.

Desta forma, o evento de crise aqui estudado tem início no ponto de máximo em maio de 2008, quando o Ibovespa alcançou a marca dos 73.516,81 pontos; e atingiu seu auge no ponto de mínimo local, em outubro de 2008, aos 29.435,10 pontos. O primeiro quarto localiza-se então por volta dos 62.500 pontos, entre $01 \mathrm{e}$ 02 de julho de 2008.

Aplicados os mesmos limites anteriores, as medidas de Complexidade ultrapassam seus limites inferiores apenas em dois momentos ${ }^{33}$, logo no início e no final da série pré-crise. Estes momentos correspondem à Crise Cambial de 1999 e a porém. Provavelmente este foi um evento de queda pontual, e não pode ser atribuído à Crise Subprime. 
Crise Subprime, objeto de estudo desta seção. Desta forma, pode-se concluir que, mais uma vez, a crise poderia ser detectada bem antes de atingir seu auge, em outubro de 2008. As amostras de crise e pré-crise e as medidas de Complexidade estão plotadas nos Gráficos 27 e 28 respectivamente.

Gráfico 27 - Ibovespa - Crise Subprime: amostras pré-crise e crise

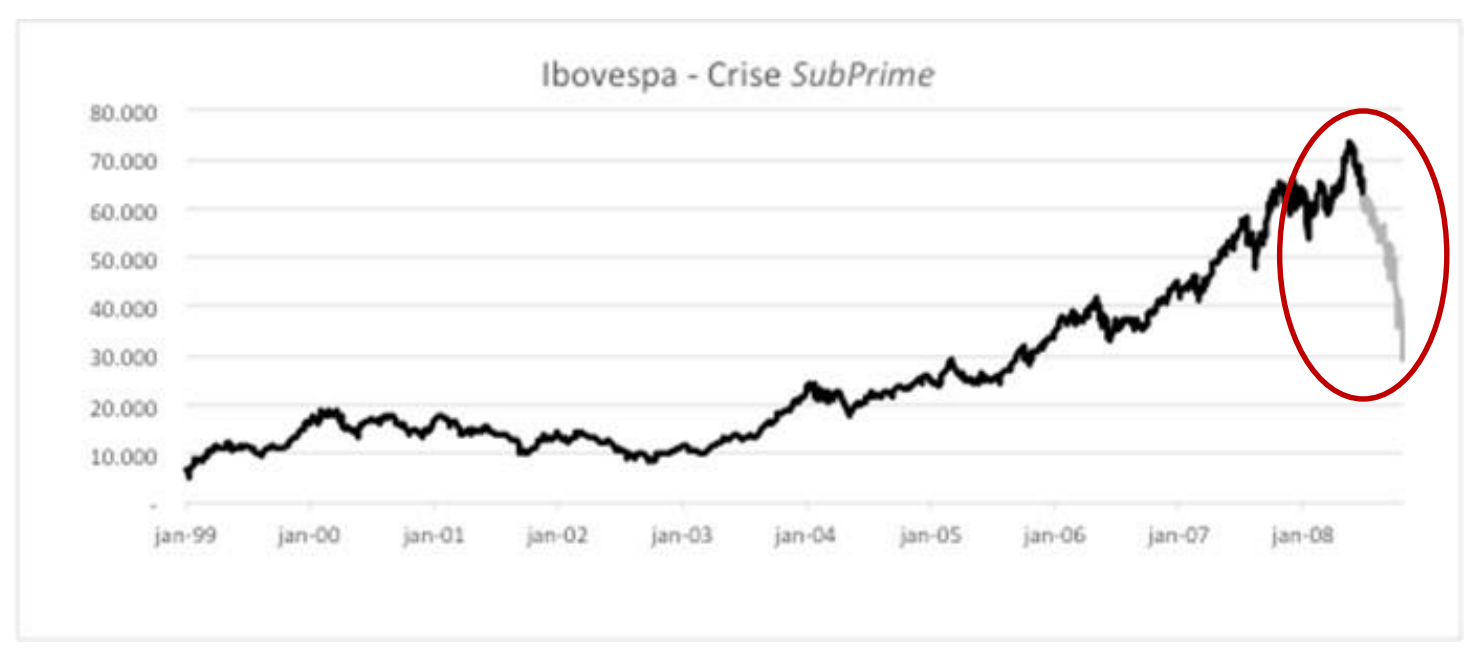

Fonte: elaborado pela autora

Gráfico 28 - Complexidade do Ibovespa - Crise Subprime

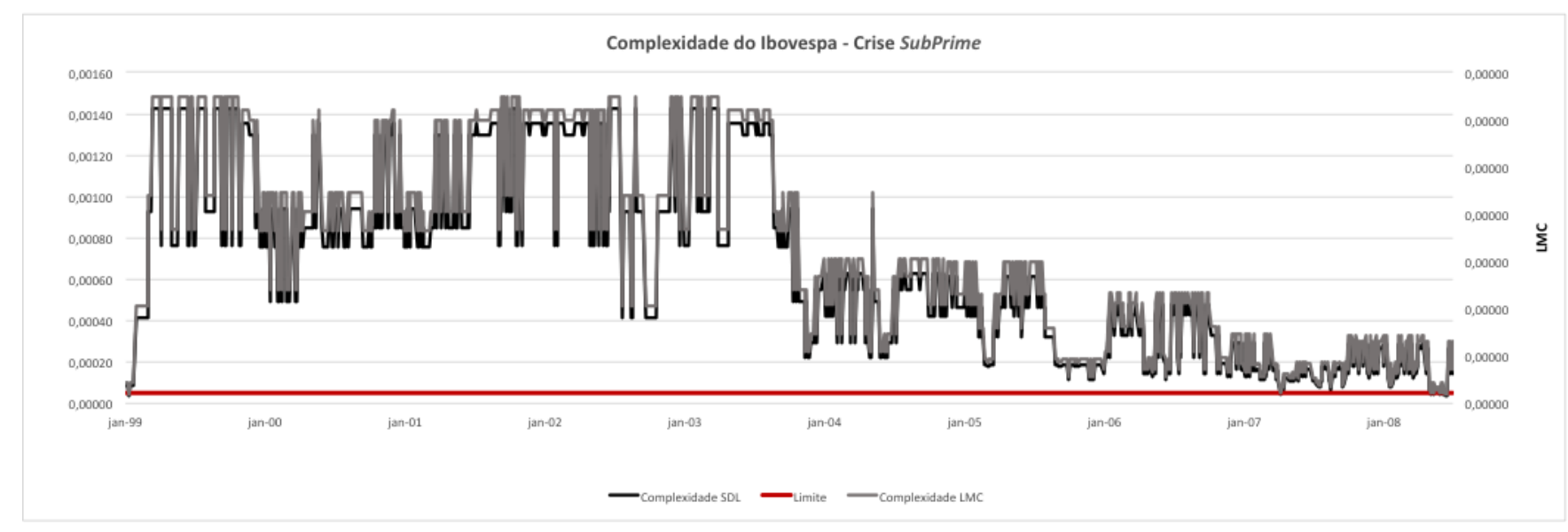

Fonte: elaborado pela autora 


\subsubsection{CDS Brasil}

Seguindo a mesma metodologia descrita nas seções anteriores, mesmo que esta seja uma série mais curta, foram testados os mesmos números de intervalos (8, 16, 32 e 64). Assim como nas demais séries de dados, a divisão da amostra em 64 intervalos mostrou-se mais eficiente, com apenas 4 faixas de dados vazias de observações. Os diferentes números de intervalos testados estão ilustrados nos gráficos que se seguem.

Gráfico 29 - Complexidade do CDS Brasil, 8 intervalos

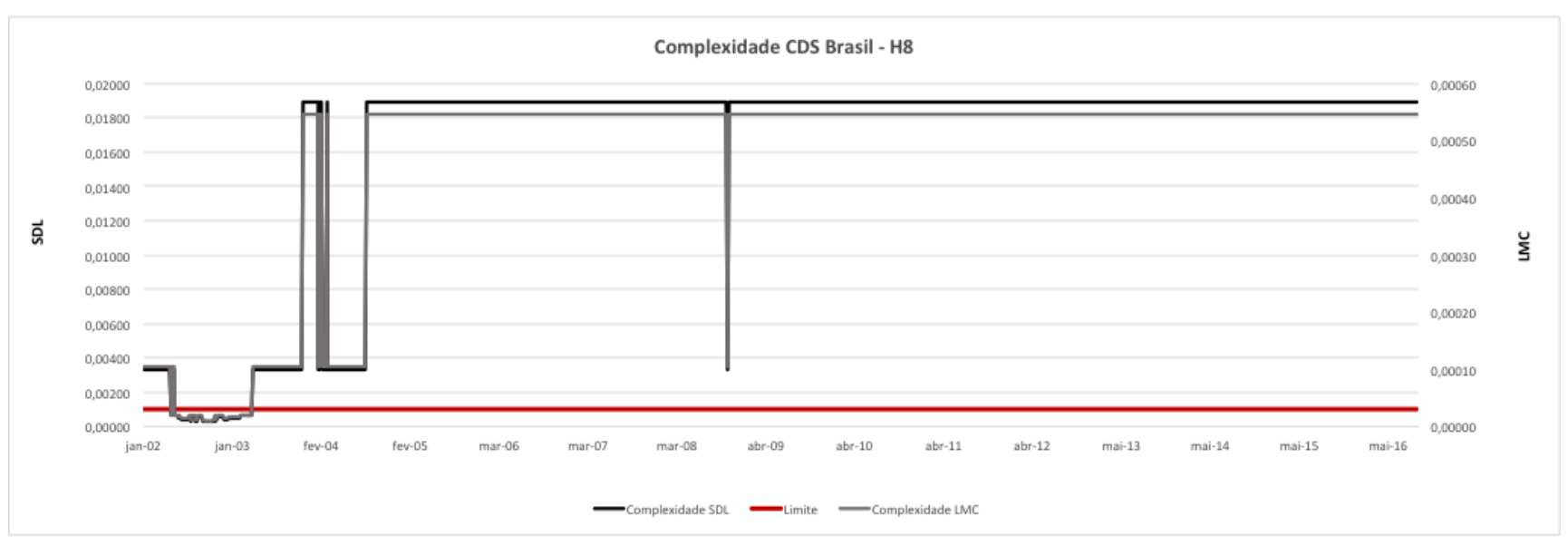

Fonte: elaborado pela autora 
Gráfico 30 - Complexidade do CDS Brasil, 16 intervalos

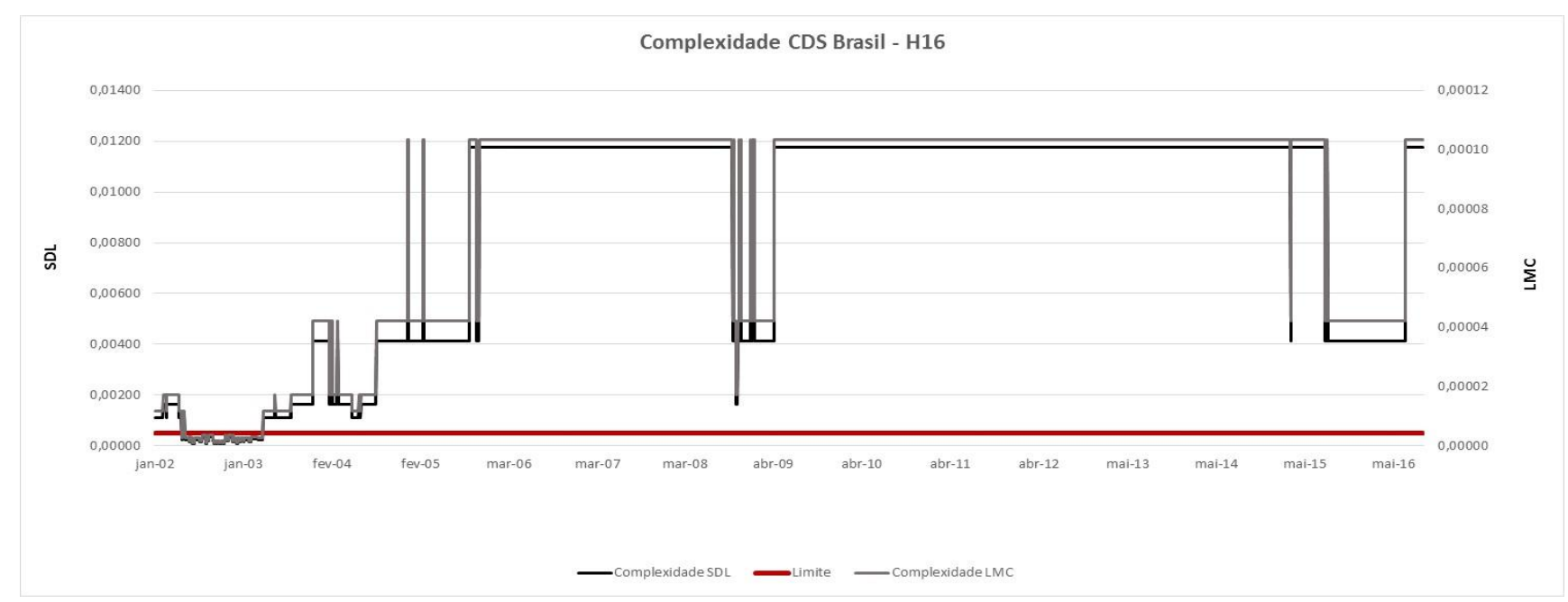

Fonte: elaborado pela autora

Gráfico 31 - Complexidade do CDS Brasil, 32 intervalos

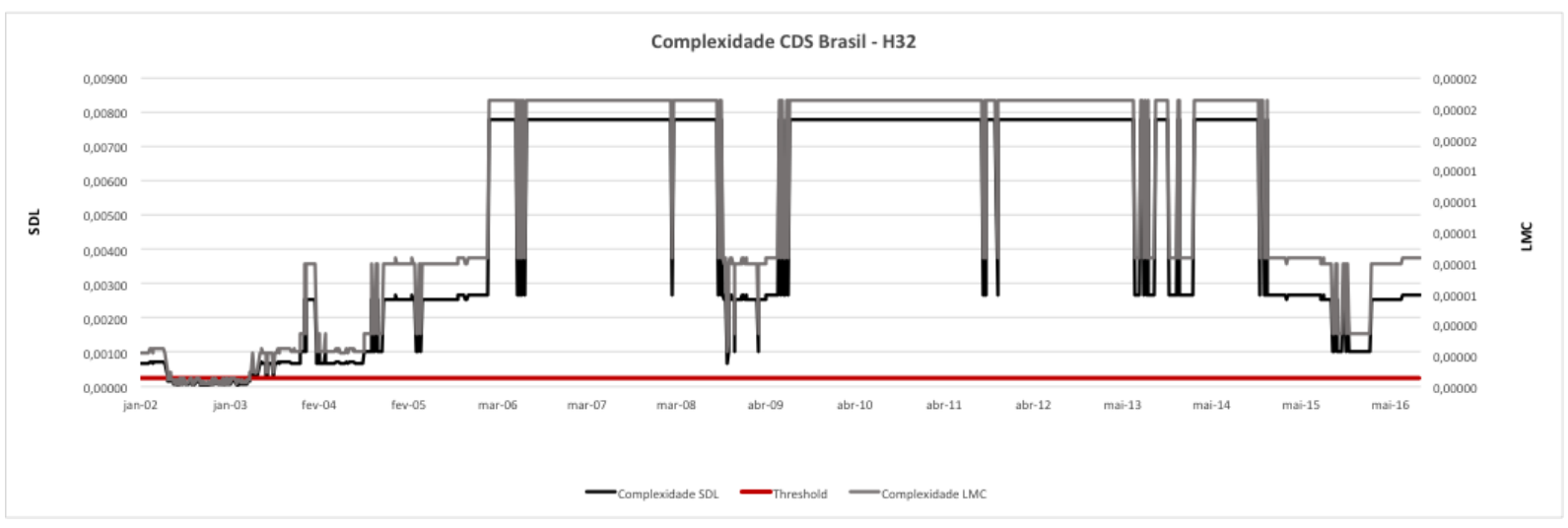

Fonte: elaborado pela autora 
Gráfico 32 - Complexidade do CDS Brasil, 64 intervalos

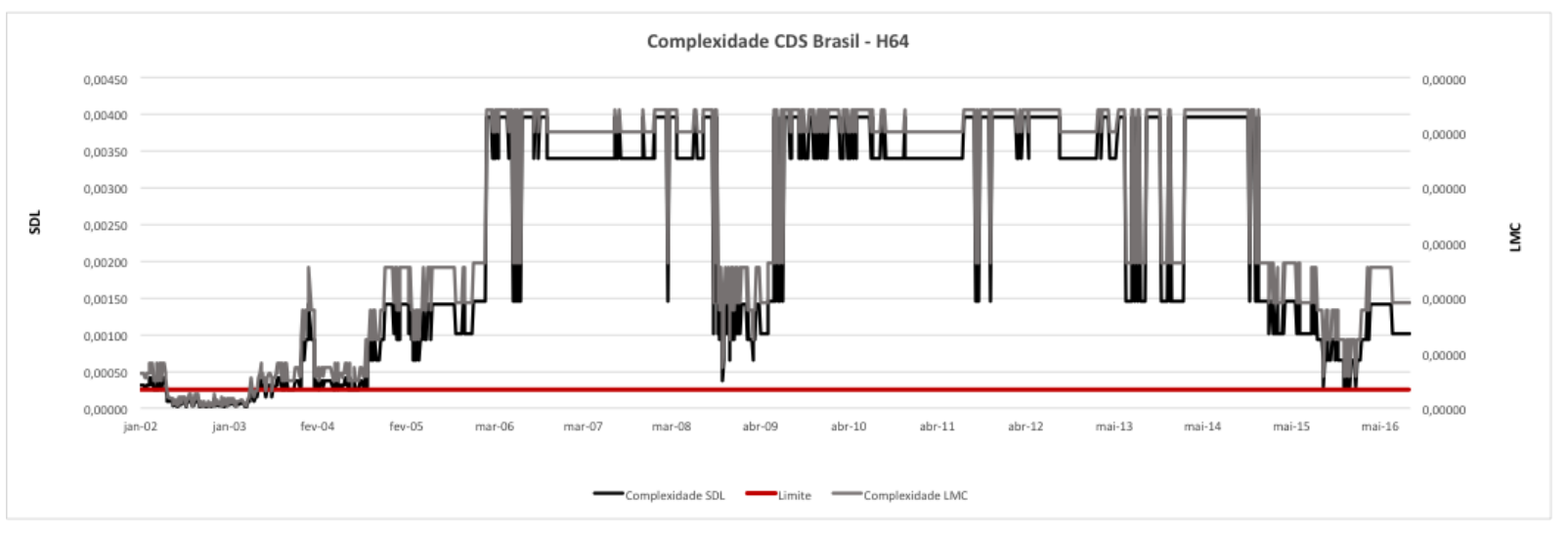

Fonte: elaborado pela autora

Dada a divisão em 64 intervalos, a Tabela 3 a seguir resume as medidas de Complexidade LMC e SDL encontradas para as diferentes faixas de dados. Pode-se observar que os valores mais baixos, tanto para a Complexidade LMC quanto para a SDL, estão localizados nos intervalos H43, H62 e H26. Como cada uma destas faixas de dados possui apenas uma observação, os valores para as medias de Complexidade são os mesmos. Estes valores acontecem em diferentes datas entre 0 segundo semestre de 2002 e o início de 2003. São seguidos por várias outras faixas para as quais existem apenas 2 observações (como H19, por exemplo), 3 observações (H27), e assim por diante. Inequivocamente, todos os pontos que estão abaixo dos limites estabelecidos $(0,00025$ para a Complexidade SDL, e 0,00000025 para a Complexidade LMC), localizam-se entre o segundo semestre de 2002 e início de 2003. Estes são, definitivamente, reflexos da Crise Pré-Eleição do Lula. Outros pontos que tocam os limites, sem ultrapassá-los, porém, ocorrem durante a Crise do Governo Dilma, ao final de 2015 e início de 2016; e meados de 2004, quando o Federal Reserve anunciou os primeiros cortes da taxa básica de juros norte americana.

Desta forma, fica claro que o principal evento de crise a ser estudado para esta série é novamente a Crise Pré-Eleição do Lula. Os principais eventos de crise para a série do CDS Brasil estão ilustrados no Gráfico 33, logo após a tabela de resultados. 
Tabela 3 - Complexidade do Ibovespa, 64 intervalos

\begin{tabular}{|c|c|c|c|c|c|c|}
\hline Intervalo & Min. & Max. & Num. Ocorrências & Probabilidade & Complexidade LMC & Complexidade SDL \\
\hline$\overline{\mathrm{H} 1}$ & 61,50 & 122,28 & 847 & $23,44 \%$ & 0,0000025036 & 0,0034011250 \\
\hline $\mathrm{H} 2$ & 122,28 & 183,06 & 1017 & $28,14 \%$ & 0,0000027125 & 0,0039581866 \\
\hline H3 & 183,06 & 243,84 & 309 & $8,55 \%$ & 0,0000013177 & 0,0014502326 \\
\hline $\mathrm{H} 4$ & 243,84 & 304,63 & 204 & $5,64 \%$ & 0,0000009576 & 0,0010141537 \\
\hline H5 & 304,63 & 365,41 & 298 & $8,25 \%$ & 0,0000012826 & 0,0014058452 \\
\hline H6 & 365,41 & 426,19 & 187 & $5,17 \%$ & 0,0000008936 & 0,0009405249 \\
\hline H7 & 426,19 & 486,97 & 121 & $3,35 \%$ & 0,0000006264 & 0,0006437785 \\
\hline H8 & 486,97 & 547,75 & 48 & $1,33 \%$ & 0,0000002846 & 0,0002849940 \\
\hline H9 & 547,75 & 608,53 & 65 & $1,80 \%$ & 0,0000003700 & 0,0003727887 \\
\hline H10 & 608,53 & 669,31 & 42 & $1,16 \%$ & 0,0000002532 & 0,0002531081 \\
\hline H11 & 669,31 & 730,09 & 41 & $1,13 \%$ & 0,0000002480 & 0,0002477402 \\
\hline H12 & 730,09 & 790,88 & 72 & $1,99 \%$ & 0,0000004040 & 0,0004080230 \\
\hline H13 & 790,88 & 851,66 & 55 & $1,52 \%$ & 0,0000003203 & 0,0003215638 \\
\hline H14 & 851,66 & 912,44 & 45 & $1,25 \%$ & 0,0000002690 & 0,0002691178 \\
\hline H15 & 912,44 & 973,22 & 24 & $0,66 \%$ & 0,0000001546 & 0,0001535821 \\
\hline H16 & 973,22 & $1.034,00$ & 15 & $0,42 \%$ & 0,0000001017 & 0,0001006840 \\
\hline H17 & $1.034,00$ & $1.094,78$ & 13 & $0,36 \%$ & 0,0000000895 & 0,0000884981 \\
\hline H18 & $1.094,78$ & $1.155,56$ & 4 & $0,11 \%$ & 0,0000000308 & 0,0000303685 \\
\hline H19 & $1.155,56$ & $1.216,34$ & 2 & $0,06 \%$ & 0,0000000163 & 0,0000161068 \\
\hline $\mathrm{H} 2 \mathrm{O}$ & $1.216,34$ & $1.277,13$ & 6 & $0,17 \%$ & 0,0000000445 & 0,0000439335 \\
\hline H21 & $1.277,13$ & $1.337,91$ & 0 & $0,00 \%$ & NA & NA \\
\hline $\mathrm{H} 22$ & $1.337,91$ & $1.398,69$ & 10 & $0,28 \%$ & 0,0000000706 & 0,0000698222 \\
\hline H23 & $1.398,69$ & $1.459,47$ & 10 & $0,28 \%$ & 0,0000000706 & 0,0000698222 \\
\hline H24 & $1.459,47$ & $1.520,25$ & 8 & $0,22 \%$ & 0,0000000578 & 0,0000570461 \\
\hline H25 & $1.520,25$ & $1.581,03$ & 4 & $0,11 \%$ & 0,0000000308 & 0,0000303685 \\
\hline H26 & $1.581,03$ & $1.641,81$ & 1 & $0,03 \%$ & 0,0000000086 & 0,0000085146 \\
\hline $\mathrm{H} 27$ & $1.641,81$ & $1.702,59$ & 3 & $0,08 \%$ & 0,0000000237 & 0,0000233507 \\
\hline H28 & $1.702,59$ & $1.763,38$ & 7 & $0,19 \%$ & 0,0000000512 & 0,0000505376 \\
\hline H29 & $1.763,38$ & $1.824,16$ & 12 & $0,33 \%$ & 0,0000000832 & 0,0000823301 \\
\hline H3O & $1.824,16$ & $1.884,94$ & 7 & $0,19 \%$ & 0,0000000512 & 0,0000505376 \\
\hline H31 & $1.884,94$ & $1.945,72$ & 3 & $0,08 \%$ & 0,0000000237 & 0,0000233507 \\
\hline H32 & $1.945,72$ & $2.006,50$ & 3 & $0,08 \%$ & 0,0000000237 & 0,0000233507 \\
\hline H33 & $2.006,50$ & $2.067,28$ & 0 & $0,00 \%$ & NA & NA \\
\hline H34 & $2.067,28$ & $2.128,06$ & 2 & $0,06 \%$ & 0,0000000163 & 0,0000161068 \\
\hline H35 & $2.128,06$ & $2.188,84$ & 2 & $0,06 \%$ & 0,0000000163 & 0,0000161068 \\
\hline H36 & $2.188,84$ & $2.249,63$ & 4 & $0,11 \%$ & 0,0000000308 & 0,0000303685 \\
\hline H37 & $2.249,63$ & $2.310,41$ & 4 & $0,11 \%$ & 0,0000000308 & 0,0000303685 \\
\hline H38 & $2.310,41$ & $2.371,19$ & 15 & $0,42 \%$ & 0,0000001017 & 0,0001006840 \\
\hline H39 & $2.371,19$ & $2.431,97$ & 6 & $0,17 \%$ & 0,0000000445 & 0,0000439335 \\
\hline $\mathrm{H} 4 \mathrm{O}$ & $2.431,97$ & $2.492,75$ & 0 & $0,00 \%$ & NA & NA \\
\hline H41 & $2.492,75$ & $2.553,53$ & 2 & $0,06 \%$ & 0,0000000163 & 0,0000161068 \\
\hline H42 & $2.553,53$ & $2.614,31$ & 4 & $0,11 \%$ & 0,0000000308 & 0,0000303685 \\
\hline $\mathrm{H} 43$ & $2.614,31$ & $2.675,09$ & 1 & $0,03 \%$ & 0,0000000086 & 0,0000085146 \\
\hline H44 & $2.675,09$ & $2.735,88$ & 7 & $0,19 \%$ & 0,0000000512 & 0,0000505376 \\
\hline H45 & $2.735,88$ & $2.796,66$ & 4 & $0,11 \%$ & 0,0000000308 & 0,0000303685 \\
\hline H46 & $2.796,66$ & $2.857,44$ & 10 & $0,28 \%$ & 0,0000000706 & 0,0000698222 \\
\hline $\mathrm{H} 47$ & $2.857,44$ & $2.918,22$ & 19 & $0,53 \%$ & 0,0000001256 & 0,0001245422 \\
\hline $\mathrm{H} 48$ & $2.918,22$ & $2.979,00$ & 2 & $0,06 \%$ & 0,0000000163 & 0,0000161068 \\
\hline H49 & $2.979,00$ & $3.039,78$ & 6 & $0,17 \%$ & 0,0000000445 & 0,0000439335 \\
\hline $\mathrm{H} 50$ & $3.039,78$ & $3.100,56$ & 4 & $0,11 \%$ & 0,0000000308 & 0,0000303685 \\
\hline H51 & $3.100,56$ & $3.161,34$ & 3 & $0,08 \%$ & 0,0000000237 & 0,0000233507 \\
\hline H52 & $3.161,34$ & $3.222,13$ & 6 & $0,17 \%$ & 0,0000000445 & 0,0000439335 \\
\hline H53 & $3.222,13$ & $3.282,91$ & 2 & $0,06 \%$ & 0,0000000163 & 0,0000161068 \\
\hline H54 & $3.282,91$ & $3.343,69$ & 2 & $0,06 \%$ & 0,0000000163 & 0,0000161068 \\
\hline H55 & $3.343,69$ & $3.404,47$ & 3 & $0,08 \%$ & 0,0000000237 & 0,0000233507 \\
\hline H56 & $3.404,47$ & $3.465,25$ & 0 & $0,00 \%$ & NA & NA \\
\hline H57 & $3.465,25$ & $3.526,03$ & 3 & $0,08 \%$ & 0,0000000237 & 0,0000233507 \\
\hline H58 & $3.526,03$ & $3.586,81$ & 8 & $0,22 \%$ & 0,0000000578 & 0,0000570461 \\
\hline H59 & $3.586,81$ & $3.647,59$ & 2 & $0,06 \%$ & 0,0000000163 & 0,0000161068 \\
\hline $\mathrm{H} 60$ & $3.647,59$ & $3.708,38$ & 2 & $0,06 \%$ & 0,0000000163 & 0,0000161068 \\
\hline H61 & $3.708,38$ & $3.769,16$ & 3 & $0,08 \%$ & 0,0000000237 & 0,0000233507 \\
\hline $\mathrm{H62}$ & $3.769,16$ & $3.829,94$ & 1 & $0,03 \%$ & 0,0000000086 & 0,0000085146 \\
\hline H63 & $3.829,94$ & $3.890,72$ & 2 & $0,06 \%$ & 0,0000000163 & 0,0000161068 \\
\hline H64 & $3.890,72$ & $3.951,50$ & 2 & $0,06 \%$ & 0,0000000163 & 0,0000161068 \\
\hline
\end{tabular}

Fonte: elaborado pela autora 
Gráfico 33 - Complexidade do CDS Brasil, 64 intervalos, e eventos de crise

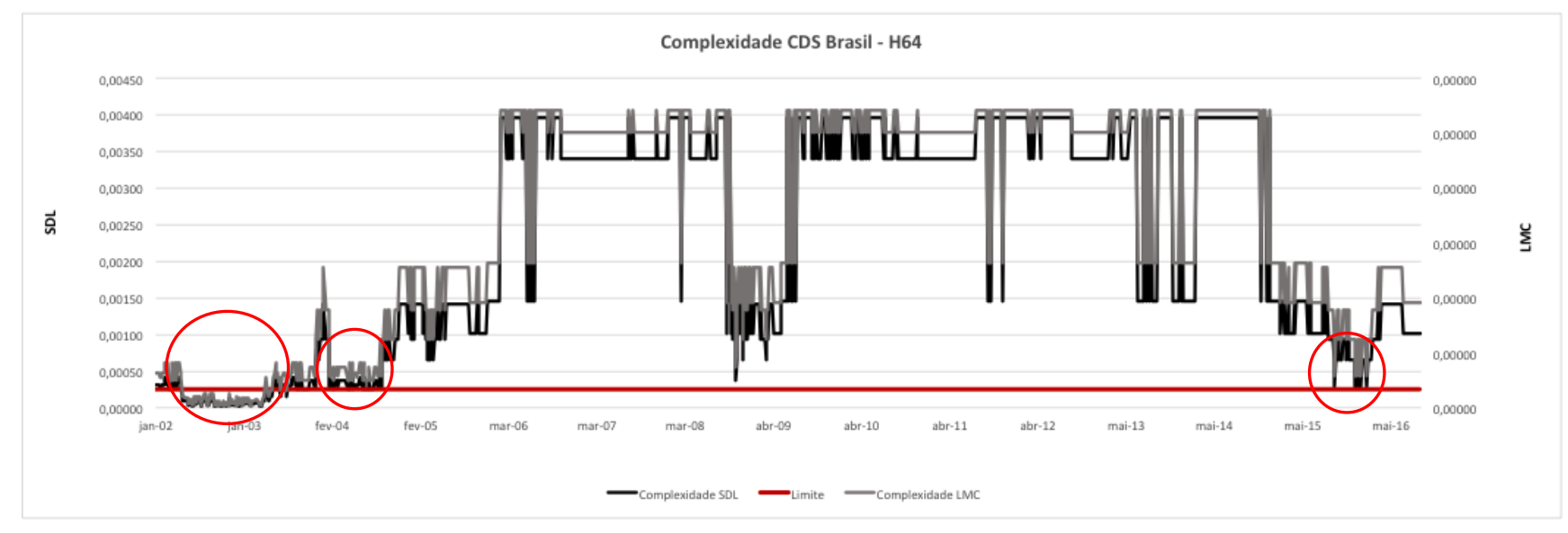

Fonte: elaborado pela autora

\subsubsection{CDS Brasil: Crise Pré-Eleição do Lula}

A Crise Pré-Eleição do Lula teve início em meados de 2002, quando as pesquisas de intenção de voto começaram a indicar o então candidato à Presidência como favorito. O mínimo local da série é de 702,50 basis points, em março de 2002. O máximo local e global da série é de $3.951,50$, em outubro de 2002. O primeiro quarto da escalada do CDS Brasil fica então em torno de 1.514,75 basis points, entre os dias 11 e 12 de junho de 2002. Estes pontos estão plotados no Gráfico 34 abaixo. Interessante notar que, em termos de distância no gráfico, o ponto de corte parece acontecer próximo ao meio da série de crise, e isto acontece porque até a metade do intervalo temporal plotado no gráfico a escalada do Risco Brasil é bem mais suave do que na metade seguinte, quando a subida exibe clara aceleração em relação ao início. 
Gráfico 34 - Complexidade do CDS Brasil, Crise Pré-Eleição do Lula

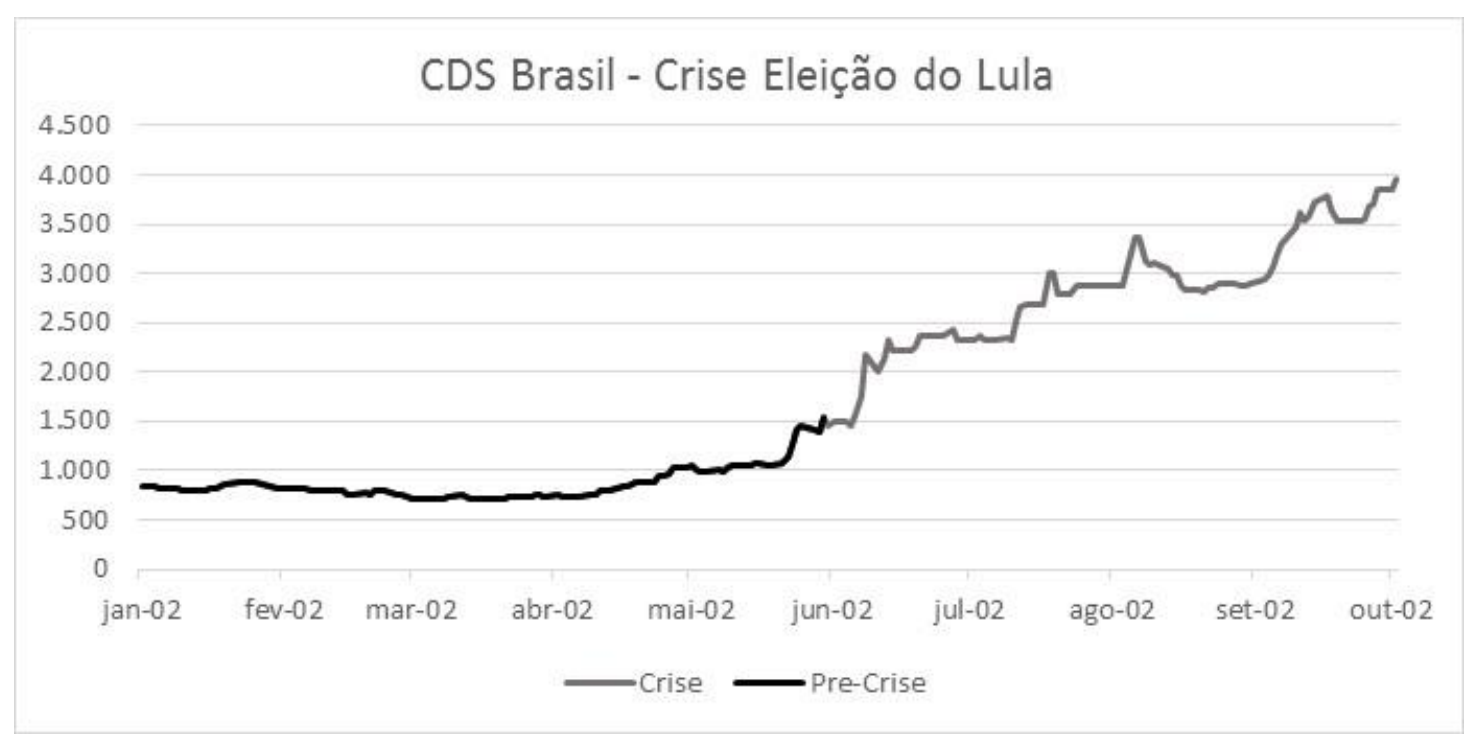

Fonte: elaborado pela autora

Aplicando-se os mesmos limites anteriores, pode-se notar que existem vários momentos em que as medidas de Complexidade cruzam os limites estabelecidos, incluindo o final da série pré-crise. Todos estes momentos fazem parte do mesmo evento de Crise, a Eleição do Lula. Desta forma, pode-se concluir que as medidas de Complexidade seriam eficientes na captura deste evento. Interessante notar que a metodologia aqui usada é robusta na detecção precoce de crises, mesmo o evento de crise estando logo no início da amostra. 
Gráfico 35 - Complexidade do CDS Brasil - Crise Pré-Eleição do Lula

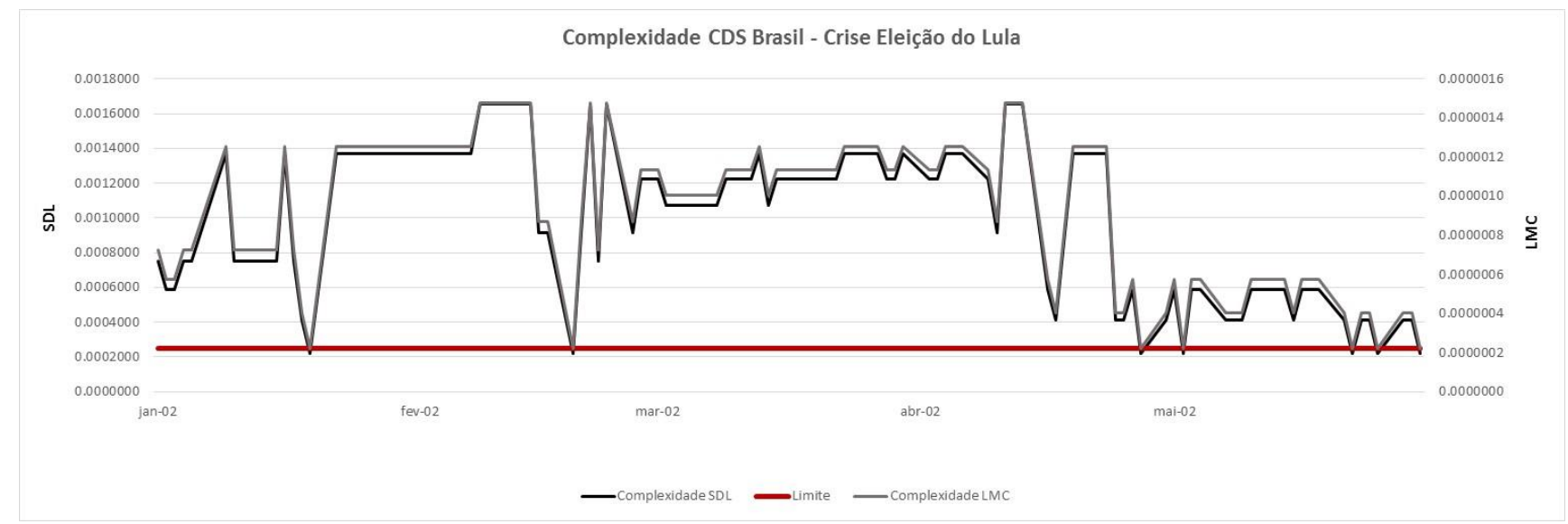

Fonte: elaborado pela autora 


\section{Conclusões}

"As far as the laws of mathematics refer to reality, they are not certain, and as far as they are certain, they do not refer to reality" (Albert Einstein).

Crises não podem ser previstas. Porém, elas podem ser antecipadas, ou detectadas em seu início. Com este intuito, este estudo busca a construção de uma medida alternativa para a detecção de eventos de crises antes que esses atinjam seu auge.

As medidas de Complexidade LMC e SDL foram aplicadas às séries financeiras brasileiras das taxas de câmbio dólar-real, Ibovespa e CDS Brasil. Cinco eventos de crises foram analisados: a Crise Cambial de 1999, o Ataque Terrorista às Torres Gêmeas de Nova Iorque em 2001, a Crise Pré-Eleição do Lula em 2002, a Crise Subprime em 2008, e a Crise do Governo Dilma Rousseff em 2015 e 2016.

Detectados os principais momentos de crise de cada série, pontos nos quais as medidas de Complexidade atingiram valores mínimos, "volta-se no tempo" para o início de cada evento e avalia-se, dada a informação disponível naquele momento, se a crise poderia ter sido detectada. Ou, de forma mais explícita, recalculadas as medidas de Complexidade com os dados disponíveis até o início da crise, estas ultrapassariam os limites mínimos estabelecidos previamente, evidenciando o início de uma crise? A resposta, em todos os casos, é sim.

Em termos das taxas de câmbio dólar-real, os principais eventos de crise foram a Crise Cambial de 1999, a Crise Pré-Eleição do Lula, e a Crise do Governo Dilma, quando estas taxas atingiram seu máximo histórico. Ambas as medidas de Complexidade apresentaram bons resultados quando aplicadas à série como um todo e analisados os eventos de crise. A Crise Cambial de 1999 acontece logo nas primeiras observações da série, impossibilitando sua análise ex-ante. Os outros dois eventos seriam claramente detectados logo em seu início, utilizada a metodologia neste estudo proposta. Adicionalmente a estes eventos, destacaram-se também os outros eventos de crise aqui estudados: a Crise Cambial de 1999 e o Ataque à Torres Gêmeas em 2001. Mais interessante ainda, a análise possibilitou detectar crises 
adicionais, como a Crise Argentina em 2011, o rebaixamento da dívida brasileira pelo JP Morgan Chase em 2004 e a Crise da Dívida Americana em 2011. Esta última, ao contrário das demais, implicou em decréscimo das taxas de câmbio, já que o dólar sofria depreciação frente a outras moedas diante da possibilidade de um default da dívida norte americana.

Para o Ibovespa, a Crise Subprime foi o evento mais significativo. A análise exante deste evento também mostrou-se frutífera, e a crise poderia ser detectada em seu início. Interessante notar que maio de 2008 também foi evidenciado nas medidas de Complexidade, como um ponto de máximo, e não uma queda abrupta. Assim como a Crise Cambial de 1999 que também foi detectada nesta análise. Aqui é importante destacar que, ao contrário da Crise Subprime quando o lbovespa caiu dramaticamente, tanto na Crise Cambial de 1999 quanto em maio de 2008, o Ibovespa, inesperadamente, subiu. Estes fatos revelam novamente a robustez da metodologia aqui proposta, já que aumentos de volatilidade são detectados tanto no caso de retornos negativos, quanto no caso de retornos positivos.

Por fim, o principal evento de Crise em termos de risco-país, representado pelo CDS Brasil, foi a Crise Pré-Eleição do Lula. Este também é claramente detectado na análise ex-ante, porém desta vez não foi possível o reconhecimento de outros eventos, já que a crise em estudo acontece logo nos primeiros meses da amostra. Ainda assim, este é um ponto positivo da metodologia aqui proposta, pois evidencia que não é necessário grande histórico de dados para que a crise seja detectada.

Em resumo, as medidas de Complexidade LMC e SDL são robustas na detecção de aumentos de volatilidade nos dados de séries financeiras. Assim sendo, apresentam grande potencial como indicadores precoces de crises financeiras. Conforme apurado neste estudo, para tal, não são necessários cálculos extensivos, nem grandes históricos de dados; e também não são necessárias hipóteses sobre a distribuição de probabilidades destes dados, o que aparenta ser uma grande vantagem, já que uma das grandes dificuldades do mundo financeiro é encontrar uma distribuição que se aproxime à realidade. Por fim, não foram encontradas diferenças qualitativas entre as duas medidas de Complexidade, os resultados de ambas convergem para as mesmas conclusões. 
Para concluir, o Brasil ainda é um país muito jovem, longe da maturidade econômica e, principalmente, política. Desta forma, apresenta um ambiente rico para o estudo de crises. A sensibilidade desta economia ao capital externo e conjuntamente ao apetite ao risco do investidor estrangeiro, é um fato que merece destaque, e faz com que o risco-país e o mercado de ações estejam intimamente ligados à entrada e saída de recursos do país e consequentemente às taxas de câmbio.

Para estudos futuros, o teste da metodologia aqui proposta para diferentes mercados (países) seria bastante intrigante. A aplicação desta metodologia em dados de alta frequência também poderia gerar resultados bem interessantes. 


\section{Referências $^{34}$}

ARCOVERDE, G. L. O Mercado de Crédito no Brasil. Notas Técnicas do Banco Central do Brasil, 15, 2002.

ARTHUR, W.B. Complexity Economics: A Different Framework for Economic Thought. Santa Fe Institute working paper, 2013.

AVERBUG, A. e GIAMBIAGI, F. A Crise Brasileira de 1998/1999 - Origens e Consequências. BNDES: Textos para Discussão - 77, 2000.

BANCO CENTRAL DO BRASIL. Análise do Mercado de Câmbio. Relatório de Política Cambial, disponível em http://www.bcb.gov.br/rex/MerCâmbio/Port/Câmbio011/2001-

1Pol\%C3\%ADticaCambial.asp - 2001.

BANCO CENTRAL DO BRASIL. Risco País, disponível em https://www.bcb.gov.br/conteudo/home-ptbr/FAQs/FAQ\%2009-

Risco\%20Pa\%C3\%ADs.pdf -2016 .

BBC News. Brazil corruption scandals: All you need to know. Disponível em: http://www.bbc.com/news/world-latin-america-35810578 - 2017.

BENTES, S.R. e MENEZES, R.M. Entropy: A new measure of stock Market volatility? Journal of Physics, Conference Series 394, 2012.

BONOMO, M. e TERRA, C. The Political Economy of Exchange Rate Policy in Brazil: 1964-1997. Fundação Getúlio Vargas, 1999.

BORDO, M. e LANE, J.L. The Lessons from Banking Panics in the United States in the 1930s for the Financial Crisis of 2007-2008. NBER Working Paper n.16365, 2010.

${ }^{34}$ De acordo com a Associação Brasileira de Normas Técnicas (ABNT NBR 6023). 
CASTRO, L.B. Esperança, Frustração e Aprendizado: a História da Nova República (1985-1989) in Economia Brasileira Contemporânea (1945-2004). Elsevier, 2005.

CERVO, A.L. e LESSA, A.C. O declínio: inserção internacional do Brasil (2011 2014). Revista Brasileira de Política Internacional, vol. 57, n.2, 2014.

CESPEDES, J.L. e DUSSOLD, C.K. The Effect of the September 11th Terrorist Attacks on World Stock Markets. Comparative Studies of South Asia, Africa and the Middle East, Spring, 2004.

Chicago Tribune. Markets Reopen, Plunge. Disponível em: http://www.chicagotribune.com/business/chi-010917markets, 0,5287650.story - 2001.

DELOITTE. Brazil: Yearning for the Good Times. Global Economic Outlook: $2^{\text {nd }}$ Quarter 2016.

DEUTSCHE BANK RESEARCH. The CDS Market: A primer. Disponível em: www.dbresearch.com

EBELING et al. Entropy, Complexity, Predictability, and Data Analysis of time Series and Letter Sequences in The Science of Disasters: Climate Disruptions, Heart Attacks, and Market Crashes. Springer, 2002.

ESTADÃO, ECONOMIA E NEGÓCIOS. Dólar cai a $\mathbf{R} \$ \mathbf{1 , 5 5}$; mercado olha EUA e intervenção local. Disponível em: http://economia.estadao.com.br/noticias/geral,dolar-cai-a-r1-55-mercado-olha-eua-eintervencao-local,77951e - 2011.

EXAME. Os dias de maior pânico na história da Bolsa Brasileira. Disponível em: http://exame.abril.com.br/mercados/os-dias-de-maior-panico-na-historia-da-bolsabrasileira/ - 2013.

FOLHA ONLINE. Wall Street recebe governo Lula com voto de confiança. Disponível em: http://www1.folha.uol.com.br/folha/reuters/ult112u23596.shtml - 2002. 
FOLHA ONLINE. Dólar interrompe quedas e fecha em alta de $0,76 \%$ após rebaixamento do Brasil. Disponível em http://www1.folha.uol.com.br/folha/dinheiro/ult91u84776.shtml - 2004.

FRACTAL FOUNDATION. What is Chaos Theory? Disponível em: http://fractalfoundation.org/resources/what-is-chaos-theory/

FRANK, N. e HESSE, H. Financial Spillovers to Emerging Markets During the Global Financial Crisis. International Monetary Fund Working Paper, n. 09/124, 2009.

GORETTI, Manuela. The Brazilian Currency Turmoil of 2002: A Nonlinear Analysis. University of Warwick, 2005.

HARTLEY, R.V.L. Transmission of Information. The Bell System Technical Journal, 1928.

INTERNATIONAL MONETARY FUND. Press Release: IMF Approves US\$30.4 Billion Stand-By Credit for Brazil. Disponível em: www.imf.org/external/np/sec/pr/2002/pr0240.htm - 2002.

JP MORGAN. The JP Morgan Guide to Credit Derivatives. Risk Publications, 1999.

LÓPEZ-RUIZ, R., MANCINI, H.L. e CALBET, X. A Statistical Measure of Complexity. Physics Letters A, 209, 1995.

MAKINEN, G. The Economic Effects of 9/11: A Retrospective Assessment (Congress Report). Disponível em: http://www.fas.org/irp/crs/RL31617.pdf - 2002.

MORTOZA, L.P.D. e PIQUEIRA, J.R.C. Measuring Complexity in Brazilian Economic Crises. PLOS ONE, 2017.

NIELSEN, M.A. e CHUANG, I.L. Entropy and Information in Quantum Computation and Quantum Information. Cambridge University Press, 2016.

NYQUIST, H. Certain Factors Affecting Telegraph Speed. The Bell System Technical Journal, 1924. 
O GLOBO. Economia Encolhe 3,6\% em 2016, e país tem a pior recessão da história. Disponível em: https://oglobo.globo.com/economia/economia-encolhe-36em-2016-pais-tem-pior-recessao-da-historia-21022917 - 2017.

PIQUEIRA, J.R.C. e MORTOZA, L.P.D. Brazilian Exchange Rate Complexity: Financial Crisis Effects. Communications in Nonlinear Science and Numerical Simulations, vol. 17, 2012.

PIQUEIRA, J.R.C., SERBONCINI, F.A. e MONTEIRO, L.H.A. Biological models: Measuring variability with classical and quantum information. Journal of Theoretical Biology,vol. 242, 2006.

PRATES, D.M. e CUNHA, A.M. Estratégias macroeconômicas depois da crise financeira global: o Brasil e os emergentes. Revista Indicadores Econômicos da Fundação de Economia e Estatística, v. 39, 2011.

RIBEIRO, J.D.T. A Crise Financeira Internacional e seus Reflexos na Política Macroeconômica do Brasil (2007-2009). Universidade de Brasília, 2010.

ROCHA, A. O câmbio e a bolsa. Valor Econômico. Disponível em: http://www.valor.com.br/valor-investe/o-estrategista/1013638/o-câmbio-e-bolsa 2011.

SANDERS, T.I. What is Complexity? Washington Center for Complexity \& Public Policy. Disponível em: http://www.complexsys.org/downloads/whatiscomplexity.pdf 2000.

SHANNON, C.E. A Mathematical Theory of Communication. The Bell System Technical Journal, Vol. 27, 1948.

SHANNON, C.E. e WEAVER, W. The Mathematical Theory of Communication. University of Illinois Press, 1964.

SHINER, J., DAVIDSON, M. e LANDSBERG, P. Simple Measure of Complexity. Physical Review E, Vol. 59, Fevereiro/1999. 
TABAK, B. The Dynamic Relationship Between Stock Prices and Exchange Rates: Evidence for Brazil. Working Paper, Banco Central do Brasil, Novembro 2006.

THE ECONOMIST. Brazil's Fall. Print edition, 02 janeiro 2016.

THE ECONOMIST. Brazilian Waxing and Waning. Economic backgrounder. Disponível ${ }^{35}$ em: https://www.economist.com/blogs/graphicdetail/2016/04/economicbackgrounder - abril 2016.

ZHOU, R., CAI, R. e TONG, G. Applications of Entropy in Finance: A Review. Entropy, 15, ZHOU, CAI e TONG (2013) 2013.

WIKIPEDIA. Ibovespa. Disponível em: https://pt.wikipedia.org/wiki/lbovespa.

WIKIPEDIA.2014-2017 Brazilian Economic Crisis. Disponível em: https://en.wikipedia.org/wiki/2014\%E2\%80\%932017_Brazilian_economic_crisis 